\title{
Hydrologic Resources Management Program and Underground Tests Area Project FY 2003 Progress Report
}

Bruton, Carol J., Eaton, Gail F., Esser, Bradley K., Finnegan, David L., Harris, Lennox J., Hu, Max, Hudson, G. Bryant, Kersting, Annie B., Moran, Jean E., Pawloski, Gayle A., Rose, Timothy P., Smith, David K., Tompson, Andrew F.B., Williams, Ross W., Zavarin, Mavrik, Zhao, Pihong

September 20, 2004 
This document was prepared as an account of work sponsored by an agency of the United States Government. Neither the United States Government nor the University of California nor any of their employees, makes any warranty, express or implied, or assumes any legal liability or responsibility for the accuracy, completeness, or usefulness of any information, apparatus, product, or process disclosed, or represents that its use would not infringe privately owned rights. Reference herein to any specific commercial product, process, or service by trade name, trademark, manufacturer, or otherwise, does not necessarily constitute or imply its endorsement, recommendation, or favoring by the United States Government or the University of California. The views and opinions of authors expressed herein do not necessarily state or reflect those of the United States Government or the University of California, and shall not be used for advertising or product endorsement purposes.

This work was performed under the auspices of the U.S. Department of Energy by University of California, Lawrence Livermore National Laboratory under Contract W-7405-Eng-48. 


\title{
Hydrologic Resources Management Program and Underground Test Area Project FY 2003 Progress Report
}

\author{
EDITORS \\ Timothy P. Rose \\ Gail F. Eaton \\ Annie B. Kersting \\ AUTHORS \\ Carol J. Bruton \\ Gail F. Eaton \\ Bradley K. Esser \\ David L. Finnegan \\ Lennox J. Harris \\ $\mathrm{Max} \mathrm{Hu}$ \\ G. Bryant Hudson \\ Annie B. Kersting \\ Jean E. Moran \\ Gayle A. Pawloski \\ Timothy P. Rose \\ David K. Smith \\ Andrew F. B. Tompson \\ Ross W. Williams \\ Mavrik Zavarin \\ Pihong Zhao
}

\section{August 2004}




\section{Table of Contents}

Introduction: Hydrologic Resources Management Program and Underground Test Area Project FY 2003 Progress Report

Chapter 1: FY 2003 Hot Well Data Summary

Chapter 2: FY 2003 Environmental Well Data Summary

Chapter 3: Radionuclide Decay and In-growth Technical Basis Document

Chapter 4: $\quad$ Results of Transmission Electron Microscopy Analysis of Individual Groundwater Colloid Samples from the Nevada Test Site

Chapter 5: Stable Isotope Investigation of Precipitation and Recharge Processes in Central Nevada 


\title{
Introduction
}

\section{Hydrologic Resources Management Program and Underground Test Area Project FY 2003 Progress Report}

\author{
Timothy P. Rose and Annie B. Kersting
}

This report describes FY 2003 technical studies conducted by the Chemical Biology and Nuclear Science Division (CBND) at Lawrence Livermore National Laboratory (LLNL) in support of the Hydrologic Resources Management Program (HRMP) and the Underground Test Area (UGTA) Project. These programs are administered by the U.S. Department of Energy, National Nuclear Security Administration Nevada Site Office (NNSA/NSO) through the Defense Programs and Environmental Restoration Divisions, respectively. HRMP-sponsored work is directed toward the responsible management of the natural resources at the Nevada Test Site (NTS), enabling its continued use as a staging area for strategic operations in support of national security. UGTA-funded work emphasizes the development of an integrated set of groundwater flow and contaminant transport models to predict the extent of radionuclide migration from underground nuclear testing areas at the NTS.

The present report is organized on a topical basis and contains five chapters that reflect the range of technical work performed by LLNL-CBND during FY 2003. Although we have emphasized investigations that were led by CBND, we also participated in a variety of collaborative studies with other UGTA and HRMP contract organizations including the Energy and Environment Directorate at LLNL (LLNL-E\&E), Los Alamos National Laboratory (LANL), the Desert Research Institute (DRI), the U.S. Geological Survey (USGS), Stoller-Navarro Joint Venture (SNJV), and Bechtel Nevada (BN).

Chapter 1 describes FY 2003 sampling efforts at NTS near-field "hot" wells, and presents new chemical and isotopic data for groundwater samples from four near-field wells. These include RNM-2S (Cambric), U-20n PS1-DDh (Cheshire), U-19q PS1d (Camembert), and U-19v PS1ds (Almendro).

Chapter 2 discusses the results of new chemical and isotopic measurements of groundwater samples from thirteen UGTA environmental monitoring wells. These include one new well in Frenchman Flat (ER-5-4 \#2), four new wells in Yucca Flat (ER-6-1 \#2, ER-12-2, ER-7-1, and ER-2-1), and eight existing wells located in the western Pahute Mesa-Oasis Valley region (ER-EC-1, ER-EC-2A, ER-EC-4, ER-EC-5, ER-EC-6, ER-EC-7, ER-EC-8, and ER-18-2).

Chapter 3 is an UGTA project Technical Basis Document co-authored by LLNL-CBND, LANL, and LLNL-E\&E staff scientists. It outlines a strategy for dealing with the in- 
growth of radioactive daughter products in contaminant transport models, and identifies the decay chains that are likely to be of greatest concern over a 1000-year time scale.

Chapter 4 provides a brief summary of recent Transmission Electron Microscope (TEM) studies of individual groundwater colloid samples from the Nevada Test Site. This work successfully used new high resolution imaging techniques to detect and identify nanoscale radionuclide colloids sorbed onto silicate colloids from NTS near-field wells.

Finally, Chapter 5 is an update on continuing stable isotope investigations of precipitation and recharge processes in central Nevada. This project was initiated in 1999 to develop a long-term monitoring record for recharge areas north of the NTS. In FY 2003, the project was expanded in cooperation with the USGS to include the isotopic analysis of precipitation samples from a network of High Altitude Precipitation (HAP) stations maintained by the USGS throughout east-central and southern Nevada. 


\section{Chapter 1}

\section{FY 2003 Hot Well Data Summary}

Timothy P. Rose, Gail F. Eaton, Ross W. Williams, Pihong Zhao, G. Bryant Hudson, Jean E. Moran, Max Hu, and Lennox J. Harris

\section{Introduction}

This report summarizes the results of chemical and isotopic analyses of groundwater samples collected from near-field "hot" wells during FY 2003. The current hot well monitoring effort is an outgrowth of the radionuclide migration program that was initiated at the Nevada Test Site (NTS) during the early 1970s (see Finnegan et al., 2004 for a historical summary). Present day efforts focus on acquiring data to assist with the development and verification of contaminant transport models for the UGTA project. Collaborating agencies include Los Alamos National Laboratory (LANL), the U.S. Geological Survey (USGS), the Desert Research Institute (DRI), Bechtel Nevada (BN), and Stoller-Navarro Joint Venture (SNJV).

Groundwater samples were collected from four NTS near-field wells during FY 2003, including RNM-2S (Cambric), U-20n PS1-DDh (Cheshire), U-19q PS1d (Camembert), and U-19v PS1ds (Almendro). Figure 1 shows the locations of these wells at the NTS. Tables 1 through 5 contain the analytical results for these samples together with comparative data for samples collected over the past several years. Table 5 also includes new ${ }^{129}$ I data for a number of "historical" samples that were analyzed during the past year. Significant features of the FY 2003 data are highlighted in the sections that follow.

LANL also prepares an annual report containing a hot well data summary, and the reader is referred to Finnegan et al. (2004) for an independent perspective on the FY 2003 hot well samples. In addition, SNJV recently compiled a comprehensive database for all historical hot well data dating back to the 1970s. This database is available electronically to UGTA and HRMP project participants (Stoller-Navarro Joint Venture, 2004a).

\section{RNM-2S (Cambric)}

The Cambric test was detonated in Frenchman Flat alluvium on 14 May 1965 at a depth of $294 \mathrm{~m}$ below the surface and $\sim 70 \mathrm{~m}$ below the water table. In 1974, a cavity re-entry hole (RNM-1) and satellite hole (RNM-2S) were drilled at the Cambric site, and starting in 1975, a 16-year pumping experiment was initiated at RNM-2S to study the transport of radionuclides under induced groundwater flow conditions. Data and interpretations related to this radionuclide migration experiment are summarized in reports by Hoffman (1977), Burbey and Wheatcraft (1986), Ogard et al., (1988), Bryant (1992), Tompson et al. (1999), and Guell and Hunt (2003). 


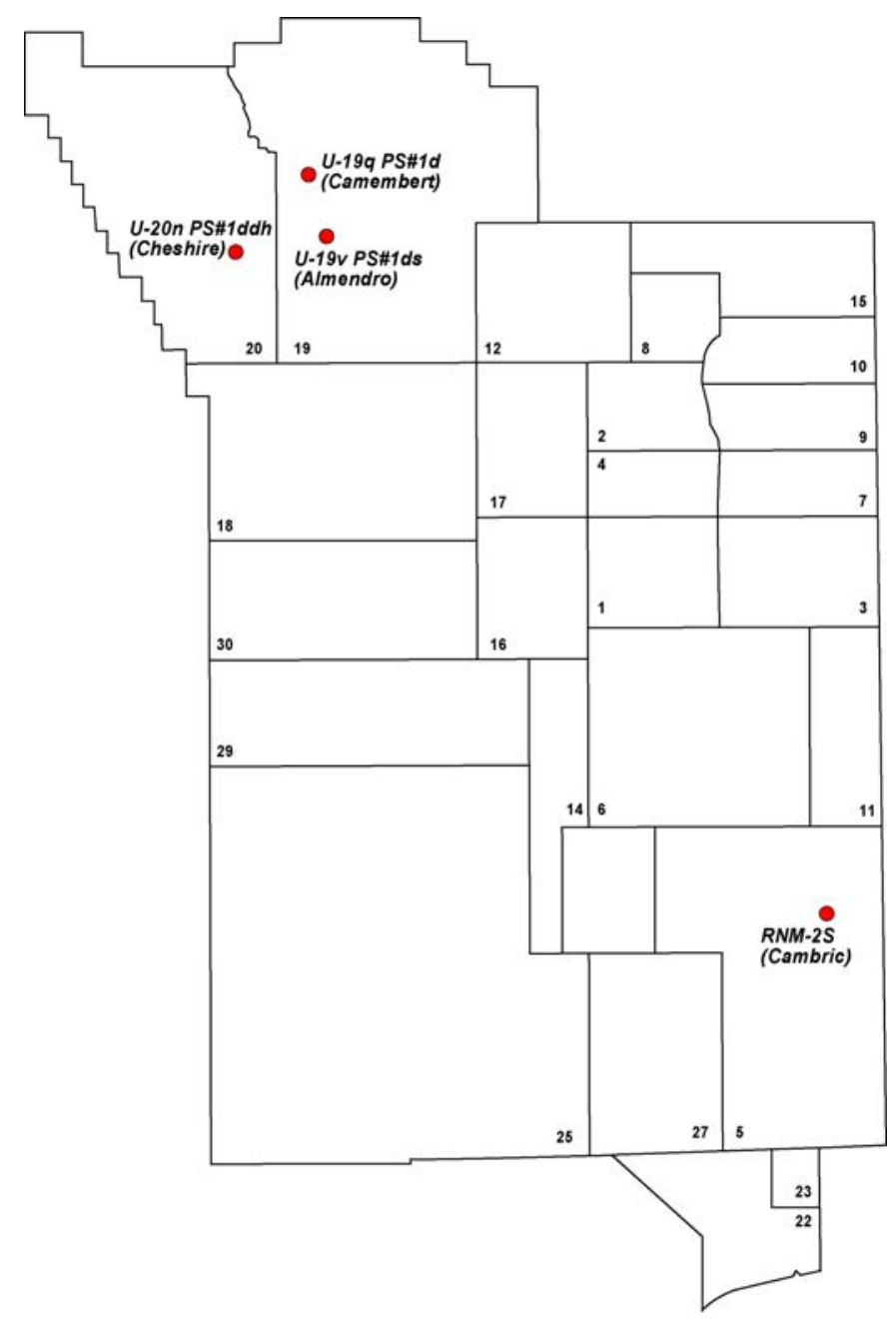

Figure 1. FY 2003 Hot well sampling locations.

The RNM-2S satellite hole is located $91 \mathrm{~m}$ south of the Cambric test working point and was drilled to a depth of $341.4 \mathrm{~m}(1,120 \mathrm{ft})$ with well perforations at 316.4 to $341.1 \mathrm{~m}$ $(1,038-1,119 \mathrm{ft})$ below the ground surface. Tritium was first observed at RNM-2S in December 1977, after more than two years of continuous pumping. A total volume of $\sim 1.5 \times 10^{6} \mathrm{~m}^{3}$ of water was pumped from RNM-2S prior to tritium breakthrough. The maximum tritium concentration was reached in July 1980, after pumping $\sim 4.8 \times 10^{6} \mathrm{~m}^{3}$ (Buddemeier and Isherwood, 1985; Guell and Hunt, 2003). Tritium concentrations have been slowly decreasing since that time. A cumulative volume of $\sim 17 \times 10^{6} \mathrm{~m}^{3}$ was pumped from RNM-2S during the 16-year duration of the radionuclide migration experiment.

In FY 2003, the UGTA project conducted a multi-well aquifer test (MWAT) to acquire data needed to assess the hydraulic properties of the alluvial aquifer in the vicinity of the Cambric test (Stoller-Navarro Joint Venture, 2004b). During this test, RNM-2S was 
pumped continuously for a period of 75 days (26 April - 10 July 2003) at an average rate of $595.5 \mathrm{gpm}$. The total volume of water pumped from RNM-2S during the MWAT was $1.83 \times 10^{5} \mathrm{~m}^{3}$ (4.85 $\times 10^{7}$ gallons), or $\sim 1 \%$ of the volume pumped during the radionuclide migration experiment. LLNL collected groundwater characterization samples from RNM-2S near the beginning of the aquifer test (09 May 2003) and again at the end of the test (10 July 2003). Prior to the 2003 MWAT, the most recent set of groundwater samples from RNM-2S were collected in 1999 and 2000 (see Rose et al., 2002a for discussion).

Water quality parameters and dissolved ion concentrations did not vary substantially over the course of the MWAT. The major ion chemistry of RNM-2S groundwater is dominated by $\mathrm{Na}^{+}$and $\mathrm{HCO}_{3}{ }^{-}$ions, and contains modest amounts of $\mathrm{SO}_{4}{ }^{2-}$ and $\mathrm{Cl}^{-}$, as is characteristic of water produced from the alluvial aquifer in Frenchman Flat. The stable isotope $\left(\delta \mathrm{D}\right.$ and $\left.\delta^{18} \mathrm{O}\right)$ composition of the water indicates it has undergone moderate amounts of evaporation relative to other Frenchman Flat groundwaters (see also Rose et al., 2002a). This observation implies that water from Cambric ditch is being recirculated into well RNM-2S (Tompson et al., 2002).

The tritium activity measured by LLNL in RNM-2S groundwater was $1.48 \times 10^{5} \mathrm{pCi} / \mathrm{L}$ on 09 May 2003 and $1.51 \times 10^{5} \mathrm{pCi} / \mathrm{L}$ on 10 July 2003 (corrected to the sample date). Decay correcting these values to time zero yields initial activities of $1.26 \times 10^{6} \mathrm{pCi} / \mathrm{L}$ and $1.30 \times 10^{6} \mathrm{pCi} / \mathrm{L}$, respectively. These results are essentially identical to those reported by Finnegan et al. (2004) and Stoller-Navarro Joint Venture (2004b). The tritium activity in RNM-2S appears to have decreased slightly relative to values measured in 1999 and 2000 (see Table 5).

Tritium decay produces a local accumulation of ${ }^{3} \mathrm{He}$ in the groundwater that can be used to estimate the mean residence time of tritium in the groundwater. The ${ }^{3} \mathrm{He} /{ }^{4} \mathrm{He}$ ratio in RNM-2S groundwater was measured at 6,600 and 1,600 times the natural atmospheric ratio in May and July 2003, respectively. The mean ${ }^{3} \mathrm{H}-{ }^{3} \mathrm{He}$ ages calculated for these samples were 20.1 and 26.9 years, respectively. Although the Cambric test was conducted 38 years before the 2003 MWAT, the first arrival of tritium at RNM-2S was only 25.5 years before the MWAT. The residence time estimated from the July 2003 sample is in reasonable agreement with this arrival time. The comparatively high $R / R_{a}$ value and low age estimate for the May 2003 sample is due to an apparent ${ }^{4} \mathrm{He}$ 'deficit' in this sample (Table 4).

Dissolved inorganic carbon (DIC) in RNM-2S groundwater showed a gradual decrease in ${ }^{14} \mathrm{C}$ concentration with time, from $413 \mathrm{pmc}$ in October 1999 to $387 \mathrm{pmc}$ in May 2003, declining to $364 \mathrm{pmc}$ in July 2003. This decrease either reflects groundwater dilution or the reaction of ${ }^{14} \mathrm{C}$ with calcite in the alluvial aquifer. Although the latter process almost certainly occurs to a limited extent, the $\delta^{13} \mathrm{C}$ value of the water (-9.5 permil in July 2003) is not consistent with substantial DIC equilibration with carbonate minerals. In contrast to the ${ }^{14} \mathrm{C}$ data, the ${ }^{36} \mathrm{Cl} / \mathrm{Cl}$ and ${ }^{129} \mathrm{I} /{ }^{127} \mathrm{I}$ ratios in $\mathrm{RNM}-2 \mathrm{~S}$ groundwater both showed slight increases from 1999 to 2003 . However, the net change in ${ }^{36} \mathrm{Cl}$ and ${ }^{129} \mathrm{I}$ values are sufficiently small that these variations may simply reflect uncertainty in the analyses. 
The ${ }^{87} \mathrm{Sr} /{ }^{86} \mathrm{Sr}$ ratio in $\mathrm{RNM}-2 \mathrm{~S}$ groundwater is similar to other groundwater samples from the alluvial and volcanic aquifers in Frenchman Flat (including UE-5n; see Table 4), and likely reflects equilibration of the water with volcanic-rich basin fill sediments. Uranium isotope ratios in $\mathrm{RNM}-2 \mathrm{~S}$ are consistent with the dissolution of natural uranium from the host rock, and do not indicate the presence of a test-derived uranium component. The May and July 2003 samples were analyzed for total plutonium (dissolved + colloidal), but $\mathrm{Pu}$ concentrations in both samples were below the detection limit of $0.2 \mathrm{pg} / \mathrm{L}$.

\section{U-20n PS1-DDh (Cheshire)}

The Cheshire test was detonated in the U-20n emplacement hole on 14 February 1976 at a depth of 3,829 $\mathrm{ft}(1,167 \mathrm{~m})$ beneath the surface of Pahute Mesa. A post-shot hole was drilled soon after the test, and later was converted to a monitoring well (U-20n PS1-DDh) for radionuclide migration investigations. The well has been modified several times over its history, but has afforded periodic access to the Cheshire cavity and/or chimney region for groundwater sampling since September 1976 (Sawyer et al., 1999). The cumulative data set that was gathered for the Cheshire site provides valuable insight into how the hydrologic source term (HST) evolves over time, and was recently used in the calibration of an HST model for the Cheshire test (Pawloski et al., 2001).

The most recent set of samples from U-20n PS1-DDh were collected on 09 July 2003. The samples were pumped from the depth interval 1,250-1,253 $\mathrm{m}(4,100-4,110 \mathrm{ft})$ below the surface, from within the Cheshire test cavity. Prior to this, the well was sampled on 12 October 1999 from the same depth interval, allowing a direct comparison of the 1999 and 2003 data sets (see Tables 2 through 5). Further discussion of the 1999 Cheshire samples is found in Rose et al. (2002a). Comparison of water quality parameters and major dissolved constituents for the 1999 and 2003 Cheshire samples (Tables 2 and 3) suggests the groundwater chemistry is reasonably invariant over time. The water has a dilute sodium bicarbonate composition that is typical of the volcanic aquifers in the eastern part of Pahute Mesa (east of the Purse Fault). The stable isotope ( $\delta \mathrm{D}$ and $\left.\delta^{18} \mathrm{O}\right)$ composition of the water reveals it is linked to the regional flow system beneath Pahute Mesa, with probable source area(s) located to the north of the NTS.

The tritium activity in the July 2003 Cheshire sample was $3.88 \times 10^{7} \mathrm{pCi} / \mathrm{L}$ (corrected to the sample date). LANL reported a slightly higher range of values between $4.0 \times 10^{7}$ and $4.24 \times 10^{7} \mathrm{pCi} / \mathrm{L}$ for the 2003 samples (Finnegan et al., 2004). In comparison, the 1999 sample had an activity of $5.1 \times 10^{7} \mathrm{pCi} / \mathrm{L}$ at the time of sampling. When these data are decay corrected to time zero, the $1999\left(1.9 \times 10^{8} \mathrm{pCi} / \mathrm{L}\right)$ and $2003\left(1.8 \times 10^{8} \mathrm{pCi} / \mathrm{L}\right)$ results suggest a small decrease in tritium with time.

The ${ }^{3} \mathrm{He} /{ }^{4} \mathrm{He}$ ratio in Cheshire groundwater is more than five orders of magnitude above the atmospheric level due to ${ }^{3} \mathrm{He}$ in-growth from tritium decay. The calculated ${ }^{3} \mathrm{H}-{ }^{3} \mathrm{He}$ age (19.5 years) is notably younger than the age of the nuclear test $(27.4$ years at the time of sampling), and is almost identical to the ${ }^{3} \mathrm{H}^{-3} \mathrm{He}$ age estimate for the 1999 sample (19.7 years). These data imply that some of the ${ }^{3} \mathrm{He}$ from tritium decay is somehow being lost from the system. 
The ${ }^{14} \mathrm{C}$ value of dissolved inorganic carbon (DIC) in Cheshire groundwater is $1.69 \times 10^{5}$ percent modern carbon (pmc), or about 1700 times the pre-nuclear testing atmospheric level. This is similar to the value measured in $1999\left(1.54 \times 10^{5} \mathrm{pmc}\right)$, and is one of the highest ${ }^{14} \mathrm{C}$ values measured for any test at the NTS in spite of the low DIC concentration in the water. The ${ }^{36} \mathrm{Cl} / \mathrm{Cl}$ ratio measured in 2003 was $2.22 \times 10^{-9}$, up slightly from $1.15 \mathrm{x}$ $10^{-9}$ in 1999 , and is four orders of magnitude above natural environmental levels. The dissolved ${ }^{129} \mathrm{I} /{ }^{127}$ I ratio also showed an increase from $4.91 \times 10^{-5}$ in 1999 to $2.74 \times 10^{-4}$ in 2003. The ${ }^{129} \mathrm{I} /{ }^{127} \mathrm{I}$ ratio measured in 2003 is $\sim 8$ orders of magnitude above the natural background level for this isotope.

Cheshire groundwater has a ${ }^{87} \mathrm{Sr} /{ }^{86} \mathrm{Sr}$ ratio indicative of water equilibration with the volcanic host rock. Although the measured ${ }^{235} \mathrm{U}^{238} \mathrm{U}$ ratio $(0.00726)$ is consistent with the natural isotopic abundance of uranium, Cheshire groundwater shows an unambiguous enrichment in test-derived ${ }^{236} \mathrm{U}$, with a ${ }^{236} \mathrm{U} /{ }^{235} \mathrm{U}$ ratio of $9.0 \times 10^{-4}$ and a ${ }^{236} \mathrm{U}$ activity of $0.76 \mathrm{pCi} / \mathrm{L}$. Enrichment in the ${ }^{234} \mathrm{U} /{ }^{238} \mathrm{U}$-activity ratio (3.54) reflects the preferential leaching of ${ }^{234} \mathrm{U}$ from uranium-bearing minerals in the host rock following $\alpha$-decay of ${ }^{238} \mathrm{U}$.

Plutonium was present at detectable levels in the 2003 Cheshire samples. Unfiltered groundwater had a total plutonium concentration of $4.1 \mathrm{pg} / \mathrm{L}$ and a ${ }^{239} \mathrm{Pu}+{ }^{240} \mathrm{Pu}$ activity of $0.31 \mathrm{pCi} / \mathrm{L}$. In comparison, the 1999 Cheshire samples contained $7.0 \mathrm{pg} / \mathrm{L} \mathrm{Pu}$ with a combined ${ }^{239} \mathrm{Pu}+{ }^{240} \mathrm{Pu}$ activity of $0.5 \mathrm{pCi} / \mathrm{L}$. Filtration experiments performed on the 2003 samples showed that $>90 \%$ of the plutonium is associated with mineral colloids in the water.

\section{U-19q PS\#1d (Camembert)}

The Camembert test was detonated in emplacement hole U-19q on 26 June 1975 at a depth of 4,304 $\mathrm{ft}(1,311.9 \mathrm{~m})$ below the surface of Pahute Mesa. The post shot re-entry hole (U-19q PS\#1d) was completed in August 1975 at a depth of 4,991 ft (1,521 m), and a $95 / 8$ " liner was emplaced below the casing to a depth of 3,665 $\mathrm{ft}(1,117 \mathrm{~m})$. The well was re-entered in 1998 for the purpose of groundwater sampling, but an obstruction was encountered below the liner at a depth of 3,690 ft $(1,125 \mathrm{~m})$. A submersible pump was installed and groundwater samples were collected from the open interval above this obstruction in October 1998. Analytical results for these samples are discussed in Smith et al. (1999). On 16 July 2003, groundwater samples were again collected from U-19q PS\#1d. However, the pump failed during the sampling operation after producing a cumulative volume of $\sim 11,200$ gallons of fluid. The probable reason for failure was the large amount of suspended sediment in the water. Although LLNL was unable to collect samples for noble gas analysis in 2003, a sufficient amount of water was obtained to perform all other scheduled analyses.

Comparing the major ion composition of the 1998 and 2003 Camembert samples, we see a major shift toward more dilute water chemistry in the latter set of samples (see Tables 2 and 3). In particular, the total dissolved inorganic carbon (TDIC as $\mathrm{HCO}_{3}{ }^{-}$) decreased from 1016 to $496 \mathrm{mg} / \mathrm{L}$, and the $\mathrm{Na}^{+}$decreased from 342 to $199 \mathrm{mg} / \mathrm{L}$. This change is 
almost certainly due to an increased flux of ambient groundwater to the pump intake. The 1998 Camembert samples showed anomalous enrichments in several chemical and isotopic parameters that suggested the system was at least partially isolated from exchange with the surrounding environment. In addition, gas samples taken from the well bore in 1998 contained $1.0 \% \mathrm{CH}_{4}$ and $8.3 \% \mathrm{H}_{2}$, but only $0.1 \% \mathrm{O}_{2}$, implying a reducing environment (see Smith et al., 1999). In contrast, the 2003 samples are closer to the expected chemistry for groundwater in this part of Pahute Mesa (e.g. Thomas et al., 2002; Rose et al., 2002b). U-19q PS\#1d groundwater also showed a decrease in stable isotope values between 1998 and 2003, particularly for $\delta^{18} \mathrm{O}$, which dropped from -14.6 to -15.0 permil.

The tritium activity at the time of sampling was $1.10 \times 10^{7} \mathrm{pCi} / \mathrm{L}$ in 2003 , compared to $2.1 \times 10^{7} \mathrm{pCi} / \mathrm{L}$ in 1998 . After correcting these data to zero time for the Camembert test, the activities are $5.4 \times 10^{7} \mathrm{pCi} / \mathrm{L}$ in 2003 and $7.8 \times 10^{7} \mathrm{pCi} / \mathrm{L}$ in 1998 . This suggests a small decrease in tritium activity between the two sampling events, and may be related to the dilution effect that was observed in the major ion chemistry. LANL reported tritium activities of 1.05 to $1.08 \times 10^{7} \mathrm{pCi} / \mathrm{L}$ at the time of sampling in 2003 (Finnegan et al., 2004), which are very close to the value obtained by LLNL.

Dissolved inorganic carbon (DIC) in U-19q PS\#1d groundwater had a ${ }^{14} \mathrm{C}$ value of $4.92 \mathrm{x}$ $10^{4} \mathrm{pmc}$ in 2003, down from a value of $1.07 \times 10^{5} \mathrm{pmc}$ in 1998. Carbon-14 activity showed an even more precipitous decrease $(1310 \mathrm{pCi} / \mathrm{L}$ in 1998 vs. $293 \mathrm{pCi} / \mathrm{L}$ in 2003$)$ due to a large decline in the DIC concentration. A modest change was observed in $\delta^{13} \mathrm{C}$ values, going from $+1.5 \%$ in 1998 to $+0.5 \%$ in 2003 , but the DIC is still unusually enriched in ${ }^{13} \mathrm{C}$ compared to Pahute Mesa environmental samples. The high $\delta{ }^{13} \mathrm{C}$ values coupled with earlier evidence of methane in the borehole are suggestive of anoxic (reducing) conditions.

The ${ }^{36} \mathrm{Cl} / \mathrm{Cl}$ ratio measured in 2003 was $7.73 \times 10^{-11}$, up slightly from $5.28 \times 10^{-11}$ in 1998. This ratio is about two orders of magnitude above the environmental levels in Pahute Mesa groundwater, but is notably attenuated relative to the expected ratio in an NTS groundwater containing $10^{7} \mathrm{pCi} / \mathrm{L}$ tritium. For example, Cheshire has a ${ }^{3} \mathrm{H}$ value that is 3.5 times the Camembert ${ }^{3} \mathrm{H}$ value, but a ${ }^{36} \mathrm{Cl} / \mathrm{Cl}$ ratio that is almost 30 times the Camembert ratio. In a more dramatic example, the Dalhart ${ }^{3} \mathrm{H}$ value is only 1.5 times the Camembert value, but the ${ }^{36} \mathrm{Cl} / \mathrm{Cl}$ ratio is 575 times the Camembert ratio (see Table 5), despite the fact that Dalhart and Camembert have very similar stable chloride concentrations.

Analysis of the ${ }^{129} \mathrm{I} /{ }^{127} \mathrm{I}$ ratios in near-field groundwaters collected over the past several years suggests that Camembert groundwater shows a ${ }^{129} \mathrm{I}$ deficit similar to that just described for ${ }^{36} \mathrm{Cl}$ (see Table 5). A possible explanation for the deficit is that ${ }^{36} \mathrm{Cl}$ and ${ }^{129} \mathrm{I}$ are less mobile than ${ }^{3} \mathrm{H}$ (or ${ }^{14} \mathrm{C}$ ), particularly during the time immediately after the test, and therefore are not distributed as widely outside the cavity environment. It is useful to bear in mind that the Camembert groundwater samples were produced from a zone approximately $100 \mathrm{~m}$ above the edge of the test cavity, whereas the Cheshire and Dalhart samples were collected within the cavity. 
The strontium isotope ratio in U-19q PS\#1d groundwater is consistent with water-rock equilibration with the volcanic aquifers beneath Pahute Mesa. The ${ }^{87} \mathrm{Sr} /{ }^{86} \mathrm{Sr}$ ratio showed a modest shift in composition between 1998 and 2003 (Table 4) that may be related to the dilution effect discussed above. The ${ }^{235} \mathrm{U} /{ }^{238} \mathrm{U}$ ratio indicates that uranium in the water is predominantly derived from natural U-bearing minerals in the aquifer, while the relatively low ${ }^{234} \mathrm{U} /{ }^{238} \mathrm{U}$-activity ratio (1.92) suggests only modest leaching of ${ }^{234} \mathrm{U}$ from the host rock. Total plutonium (dissolved + colloidal) was analyzed in the 2003 sample, but the $\mathrm{Pu}$ concentration was below the detection limit of $0.2 \mathrm{pg} / \mathrm{L}$.

\section{U-19v PS\#1ds (Almendro)}

The Almendro test was conducted on 06 June 1973 at a depth of $3,487 \mathrm{ft}(1,063 \mathrm{~m})$ beneath the surface of Pahute Mesa. A post-shot re-entry hole U-19v PS\#1ds was drilled through the Almendro cavity to a vertical depth of $3,837 \mathrm{ft}(1,169.5 \mathrm{~m})$. The first set of groundwater characterization samples were collected at this site in 1993, and subsequent samples were collected in 1996, 1998, 1999, 2000, and 2001. Sampling was conducted with a wireline bailer due to: (1) the narrow diameter of the borehole, and (2) the elevated water temperature in the cavity region. A borehole temperature log run in 1996 recorded a maximum value of $157^{\circ} \mathrm{C}$ at $1,073 \mathrm{~m}$ vertical depth. These data imply the Almendro test cavity is effectively isolated from the surrounding groundwater environment.

Groundwater samples were most recently collected at U-19v PS\#1ds on 23 July 2003 using the USGS wireline bailer. The sampling depth was 3,098 $\mathrm{ft}(941.5 \mathrm{~m})$ below the surface (vertical). Samples collected in 2000 and 2001 are from the same depth. The chemical characteristics of the water have remained fairly consistent over time, although absolute concentrations have varied somewhat (Tables 2 and 3). The water contains $\mathrm{Na}^{+}$ and $\mathrm{HCO}_{3}{ }^{-}$as the major dissolved ions, with relatively high $\mathrm{Cl}^{-}(53.2 \mathrm{mg} / \mathrm{L})$ and low $\mathrm{SO}_{4}{ }^{2-}(0.8 \mathrm{mg} / \mathrm{L})$ concentrations. Almendro cavity water also shows strong enrichments in selected trace elements, including Fe $(10.6 \mathrm{mg} / \mathrm{L})$, As $(1.3 \mathrm{mg} / \mathrm{L}), \mathrm{Mo}(1.2 \mathrm{mg} / \mathrm{L})$ and $\mathrm{Pb}(0.08 \mathrm{mg} / \mathrm{L})$, although the concentrations of these species have fluctuated over time by more than an order of magnitude in some cases. The U-19v PS\#1ds samples show a strong ${ }^{18} \mathrm{O}$-enrichment relative to other Pahute Mesa regional groundwaters, but lack a correlated enrichment in deuterium. This is interpreted to reflect oxygen isotope exchange between the water and rock at elevated temperatures, a process that is wellknown in natural geothermal systems.

The tritium activity in U-19v PS\#1ds groundwater was $1.14 \times 10^{8} \mathrm{pCi} / \mathrm{L}$ at the time of sampling in July 2003. LANL reported tritium values of 1.22 to $1.25 \times 10^{8} \mathrm{pCi} / \mathrm{L}$ for samples collected at the same time (Finnegan et al., 2004). The 2003 sample shows the lowest tritium activity of all recent samples from U-19v PS\#1ds. The ${ }^{3} \mathrm{He} /{ }^{4} \mathrm{He}$ ratio in 2003 was $5.82 \times 10^{4}$ times the ratio in air, but the samples show a strong ${ }^{3} \mathrm{He}$-depletion relative to the expected ${ }^{3} \mathrm{He}$ value (on the basis of tritium activity and the time elapsed since the test). The calculated ${ }^{3} \mathrm{H}-{ }^{3} \mathrm{He}$ age of the water is only 0.4 years, indicating that helium is lost from the system almost as quickly as it grows-in from tritium decay. 
Dissolved inorganic carbon continues to exhibit very high $\delta^{13} \mathrm{C}$ values $(+35.4 \%$ in 2003$)$ in U-19v PS\#1ds groundwater. The ${ }^{13} \mathrm{C}$-enrichment is consistent with methanogenic reduction of $\mathrm{CO}_{2}$, which is associated with a large isotopic fractionation between $\mathrm{CH}_{4}$ and $\mathrm{CO}_{2}$. These data, together with the $\delta^{18} \mathrm{O}$ and temperature data for Almendro provide a strong indication that the Almendro cavity has undergone very limited mass exchange with the surrounding environment. The ${ }^{14} \mathrm{C}$ value of the DIC is $2.99 \times 10^{4} \mathrm{pmc}$, which is slightly lower than the 2001 value of $3.11 \times 10^{4}$ pmc. The ${ }^{14} \mathrm{C}$ activity in the 2003 sample was $74 \mathrm{pCi} / \mathrm{L}$.

The ${ }^{36} \mathrm{Cl} / \mathrm{Cl}$ ratio in $\mathrm{U}-19 \mathrm{v}$ PS\#1ds groundwater is $3.20 \times 10^{-9}$, nearly four orders of magnitude above the natural environmental level for this region. ${ }^{36} \mathrm{Cl} / \mathrm{Cl}$ ratios are fairly consistent over time in the Almendro cavity fluid. Over the past year, ${ }^{129} \mathrm{I} /{ }^{127} \mathrm{I}$ ratios were measured for Almendro samples that were collected in 1999, 2000, 2001, and 2003 (see Table 5). These samples consistently exhibit the highest ${ }^{129} \mathrm{I} /{ }^{127} \mathrm{I}$ ratios of any near-field well at the NTS (1.89 $\times 10^{-3}$ in the 2003 sample) although the low concentration of dissolved iodine and long half-life translates to a fairly low activity $(2.54 \mathrm{pCi} / \mathrm{L}$ in 2003$)$.

Almendro cavity fluid has a ${ }^{87} \mathrm{Sr} /{ }^{86} \mathrm{Sr}$ ratio similar to other volcanic aquifer waters from Pahute Mesa. The observed strontium isotope values are consistent with water-rock equilibration processes. The ${ }^{235} \mathrm{U} /{ }^{238} \mathrm{U}$ ratio $(0.00725)$ reveals that most of the dissolved uranium is natural in origin, and the low ${ }^{234} \mathrm{U}^{238} \mathrm{U}$-activity ratio (1.27) implies that ${ }^{234} \mathrm{U}$ and ${ }^{238} \mathrm{U}$ are close to secular equilibrium. The close-to-secular-equilibrium condition is consistent with bulk dissolution of the wall rock and/or melt glass (Paces et al., 2002), and may be facilitated by the high temperature conditions within the cavity. The lack of measurable enrichment in ${ }^{235} \mathrm{U}$ in the water is probably due to the large amount of natural uranium in the rocks, which masks the small contribution of enriched ${ }^{235} \mathrm{U}$ from the test. Almendro samples were also analyzed for ${ }^{236} \mathrm{U}$ (which originates only from the test), but surprisingly, it was not detected, even though ${ }^{236} \mathrm{U}$ was present at low levels in the 2000 and 2001 samples. Equally surprising is the fact that plutonium was not detected in the 2003 samples. Pu was previously observed in Almendro fluid samples collected in 1999 and 2001, although the two sets of values vary by more than an order of magnitude (Tables 3 and 5). We do not presently have a good explanation for the lack of consistency in the Pu data. It is possible that the physiochemical conditions within the Almendro test cavity are evolving over time, which may influence (among other things) the redox state of the groundwater. We recommend that future hot well sampling operations include field measurements of several different redox couples. This will allow us to develop constraints on the redox state of near-field water samples, and monitor for changes in redox conditions over time.

\section{References}

Bryant, E.A. (1992) The Cambric Migration Experiment - A Summary Report. Los Alamos National Laboratory Report, LA-12335, September 1992.

Buddemeier, R.W., and Isherwood, D. (1985) Radionuclide Migration Project - 1984 Progress Report. Lawrence Livermore National Laboratory Report, UCRL-53628, April 1985, 71 p. 
Burbey, T.J., and Wheatcraft, S.W. (1986) Tritium and chlorine-36 migration from a nuclear explosion cavity. Desert Research Institute, Water Resources Center Publication \#45050, University of Nevada, Reno, April 1986, 103 p.

Finnegan, D.L., Thompson, J.L., and Martinez, B.A. (2004) Laboratory and Field Studies Related to Radionuclide Migration at the Nevada Test Site in Support of the Underground Test Area Project and Hydrologic Resources Management Program, October 1, 2002 September 30, 2003. Los Alamos National Laboratory Report, LA-14151-PR, May 2004, $25 \mathrm{p}$.

Guell, M.A., and Hunt, J.R. (2003) Groundwater transport of tritium and krypton 85 from a nuclear detonation cavity. Water Resources Research, v. 39, p. 1175-1185.

Hoffman, D.C. (1977) Radioactivity in the underground environment of the Cambric nuclear explosion at the Nevada Test Site. Los Alamos National Laboratory Report LA-6877-MS, July 1977,89 p.

Ogard, A.E., Thompson, J.L., Rundberg, R.S., Wolfsberg, K., Kubic, P.W., Elmore, D., and Bentley, H.W. (1988) Migration of chlorine-36 and tritium from an underground nuclear test. Radiochimica Acta, v. 44/45, p. 213-217.

Paces, J.B., Ludwig, K.R., Peterman, Z.E., and Neymark, L.A. (2002) ${ }^{234} U /{ }^{238}$ U evidence for local recharge and patterns of groundwater flow in the vicinity of Yucca Mountain, Nevada, USA. Applied Geochemistry, v. 17, p. 751-779.

Pawloski, G.A., Tompson, A.F.B., and Carle, S.F., eds. (2001) Evaluation of the hydrologic source term from underground nuclear tests on Pahute Mesa at the Nevada Test Site: The CHESHIRE test. Lawrence Livermore National Laboratory Report UCRL-ID-147023, May 2001.

Rose, T.P., Eaton, G.F., and Yamamoto, R.I., eds. (2002a) Hydrologic Resources Management Program and Underground Test Area Project FY 2000 Progress Report. Lawrence Livermore National Laboratory Report, UCRL-ID-145167, June 2002, 141 p.

Rose, T.P., Benedict, F.C., Jr., Thomas, J.M., Sicke, W.S., Hershey, R.L., Paces, J.B., Farnham, I.M., and Peterman, Z.E. (2002b) Geochemical data analysis and interpretation of the Pahute Mesa - Oasis Valley groundwater flow system, Nye County, Nevada. Lawrence Livermore National Laboratory, preliminary report prepared for the U.S. Department of Energy, Nevada Operations Office, Environmental Restoration Division, August 2002, $607 \mathrm{p}$.

Sawyer, D.A., Thompson, J.L., and Smith, D.K. (1999) The CHESHIRE migration experiment: A summary report. Los Alamos National Laboratory Report LA-13555-MS, October 1999, $32 \mathrm{p}$.

Smith, D.K., Eaton, G.F., Rose, T.P., Kenneally, J.M., Hudson, G.B., Davisson, M.L., Benedict, F.C., Jr., and Criss, R.E. (1999) Hydrologic Resources Management Program and Underground Test Area FY 1998 Progress Report. Lawrence Livermore National Laboratory Report, UCRL-ID-135170, July 1999, 76 p. 
Stoller-Navarro Joint Venture (2004a) Underground Test Area Project NEARFIELD03rev1.mdb Groundwater Chemistry Database for Nearfield Wells at the Nevada Test Site, Rev. 1, May 2004.

Stoller-Navarro Joint Venture (2004b) Integrated Data Report for the RNM-2s Multi-Well Aquifer Test at Frenchman Flat, Nevada Test Site, Nevada, Rev. 0, May 2004, 150 p.

Thomas, J.M., Benedict, F.C., Jr., Rose, T.P., Hershey, R.L., Paces, J.B., Peterman, Z.E., Farnham, I.M., Johannesson, K.H., Singh, A.K., Stetzenbach, K.J., Hudson, G.B., Kenneally, J.M., Eaton, G.F., and Smith, D.K. (2002) Geochemical and isotopic interpretations of groundwater flow in the Oasis Valley flow system, southern Nevada. Desert Research Institute, Water Resources Center Publication No. 45190.

Tompson, A.F.B., Bruton, C.J., and Pawloski, G.A., eds. (1999) Evaluation of the hydrologic source term from underground nuclear tests in Frenchman Flat at the Nevada Test Site: The CAMBRIC test. Lawrence Livermore National Laboratory Report, UCRL-ID-132300, March 1999, $355 \mathrm{p}$.

Tompson, A.F.B., Smith, D.K., and Hudson, G.B. (2002) Analysis of radionuclide migration through a $200-\mathrm{m}$ vadose zone following a 16-year infiltration event. Lawrence Livermore National Laboratory Report, UCRL-ID-146979, January 2002, 27 p. 
Table 1. Hotwell construction data and sampling information.

\begin{tabular}{|c|c|c|c|c|c|c|c|c|c|c|c|c|}
\hline Well name & Test Name & Test Date & $\begin{array}{l}\text { Latitude } \\
\text { (d m s) }\end{array}$ & $\begin{array}{l}\text { Longitude } \\
\qquad \text { (d m s) }\end{array}$ & $\begin{array}{c}\text { Surface } \\
\text { Elevation } \\
\text { (ft) }\end{array}$ & $\begin{array}{c}\text { Well Depth } \\
\text { (ft bgs) }\end{array}$ & $\begin{array}{c}\text { Open Interval } \\
\text { (ft bgs) }\end{array}$ & $\begin{array}{c}\text { Volume } \\
\text { Pumped } \\
\text { (gal) }\end{array}$ & $\begin{array}{l}\text { Water } \\
\text { Depth } \\
\text { (ft bgs) }\end{array}$ & $\begin{array}{l}\text { Sample } \\
\text { Method }\end{array}$ & $\begin{array}{l}\text { Sample } \\
\text { Depth } \\
\text { (ft bgs) }\end{array}$ & $\begin{array}{l}\text { Sample } \\
\text { date }\end{array}$ \\
\hline \multicolumn{13}{|c|}{ Hot Wells - Frenchman Flat } \\
\hline $\begin{array}{l}\text { UE5n } \\
\text { UE5n }\end{array}$ & $\begin{array}{l}\text { Cambric } \\
\text { Cambric }\end{array}$ & $\begin{array}{l}\text { 14-May-65 } \\
\text { 14-May-65 }\end{array}$ & $\begin{array}{l}364934 \\
364934\end{array}$ & $\begin{array}{l}1160659 \\
1160659\end{array}$ & $\begin{array}{l}3112 \\
3112\end{array}$ & $\begin{array}{l}1690 \\
1690\end{array}$ & $\begin{array}{l}720-730 \\
720-730\end{array}$ & --- & $\begin{array}{l}702 \\
705\end{array}$ & $\begin{array}{l}\text { pump } \\
\text { pump }\end{array}$ & $\begin{array}{l}\text { composite } \\
\text { composite }\end{array}$ & $\begin{array}{l}\text { 19-Apr-01 } \\
\text { 09-Sep-99 }\end{array}$ \\
\hline RNM-1 & Cambric & 14-May-65 & 364928 & 1155801 & 3135 & $1302 \dagger$ & $1063-1075 \dagger$ & --- & $789 \dagger$ & pump & composite & 28-Jun-00 \\
\hline $\begin{array}{l}\text { RNM-2S } \\
\text { RNM-2S } \\
\text { RNM-2S } \\
\text { RNM-2S }\end{array}$ & $\begin{array}{l}\text { Cambric } \\
\text { Cambric } \\
\text { Cambric } \\
\text { Cambric }\end{array}$ & $\begin{array}{l}\text { 14-May-65 } \\
\text { 14-May-65 } \\
\text { 14-May-65 } \\
\text { 14-May-65 }\end{array}$ & $\begin{array}{lll}36 & 49 & 21 \\
36 & 49 & 21 \\
36 & 49 & 21 \\
36 & 49 & 21\end{array}$ & $\begin{array}{l}1155801 \\
1155801 \\
1155801 \\
1155801\end{array}$ & $\begin{array}{l}3133 \\
3133 \\
3133 \\
3133\end{array}$ & $\begin{array}{l}1120 \\
1120 \\
1120 \\
1120\end{array}$ & $\begin{array}{l}1038-1119 \\
1038-1119 \\
1038-1119 \\
1038-1119\end{array}$ & $\begin{array}{c}6.39 \mathrm{E}+07 \\
1.00 \mathrm{E}+07 \\
--- \\
---\end{array}$ & $\begin{array}{l}723 \\
723 \\
723 \\
723\end{array}$ & $\begin{array}{l}\text { pump } \\
\text { pump } \\
\text { pump } \\
\text { pump }\end{array}$ & $\begin{array}{l}\text { composite } \\
\text { composite } \\
\text { composite } \\
\text { composite }\end{array}$ & $\begin{array}{c}10-J u l-03 \\
09-M a y-03 \\
14-J u n-00 \\
11-O c t-99\end{array}$ \\
\hline \multicolumn{13}{|c|}{ Hot Wells - Yucca Flat } \\
\hline $\begin{array}{l}\text { U4u PS2a } \\
\text { U4u PS2a }\end{array}$ & $\begin{array}{l}\text { Dalhart } \\
\text { Dalhart }\end{array}$ & $\begin{array}{l}13-O c t-88 \\
13-O c t-88\end{array}$ & $\begin{array}{l}370513 \\
370513\end{array}$ & $\begin{array}{l}1160251 \\
1160251\end{array}$ & $\begin{array}{l}4117 \\
4117\end{array}$ & $\begin{array}{l}2280 \\
2280\end{array}$ & $\begin{array}{l}1548-1644 \\
1548-1644\end{array}$ & $\begin{array}{l}--- \\
---\end{array}$ & $\begin{array}{l}1636 \\
1636\end{array}$ & $\begin{array}{l}\text { pump } \\
\text { pump }\end{array}$ & $\begin{array}{l}\text { composite } \\
\text { composite }\end{array}$ & $\begin{array}{l}\text { 09-Oct-03 } \\
\text { 16-Aug-99 }\end{array}$ \\
\hline UE-7ns & Bourbon & 20-Jan-67 & 370556 & 1160009 & 4369 & 2205 & 1995-2199 & --- & 1969 & bailer & 2025 & 21-Aug-01 \\
\hline UE-2ce & Nash & 19-Jan-67 & 370831 & 1160807 & 4764 & 1650 & $1385-1624$ & --- & 1470 & bailer & 1550 & 22-Aug-01 \\
\hline $\begin{array}{l}\text { U-3cn PS \#2 } \\
\text { Hot Wells - Pahı }\end{array}$ & $\begin{array}{l}\text { Bilby } \\
\text { Mesa }\end{array}$ & 13-Sep-63 & 370338 & 1160119 & 3994 & 2603 & $1680-1729$ & --- & 1550 & pump & composite & 18-Dec-01 \\
\hline $\begin{array}{l}\text { U20n PS1 DDh } \\
\text { U20n PS1 DDh }\end{array}$ & $\begin{array}{l}\text { Cheshire } \\
\text { Cheshire }\end{array}$ & $\begin{array}{l}14-F e b-76 \\
14-F e b-76\end{array}$ & $\begin{array}{lll}37 & 1425 \\
37 & 1425\end{array}$ & $\begin{array}{l}1162524 \\
1162524\end{array}$ & $\begin{array}{l}6468 \\
6468\end{array}$ & $\begin{array}{l}4253 \\
4253\end{array}$ & $\begin{array}{l}4100-4110 \\
4100-4110\end{array}$ & $\begin{array}{c}2.40 \mathrm{E}+04 \\
---\end{array}$ & 2051 & $\begin{array}{l}\text { pump } \\
\text { pump }\end{array}$ & $\begin{array}{l}\text { composite } \\
\text { composite }\end{array}$ & $\begin{array}{l}\text { 09-Jul-03 } \\
\text { 12-Oct-99 }\end{array}$ \\
\hline $\begin{array}{l}\text { U19q PS1d } \\
\text { U19q PS1d }\end{array}$ & $\begin{array}{l}\text { Camembert } \\
\text { Camembert }\end{array}$ & $\begin{array}{l}\text { 26-Jun-75 } \\
26-J u n-75\end{array}$ & $\begin{array}{l}371649 \\
371649\end{array}$ & $\begin{array}{l}1162154 \\
1162154\end{array}$ & $\begin{array}{l}--- \\
---\end{array}$ & $\begin{array}{l}--- \\
---\end{array}$ & $\begin{array}{l}--- \\
---\end{array}$ & $\begin{array}{l}1.12 \mathrm{E}+04 \\
1.47 \mathrm{E}+04\end{array}$ & 2185 & $\begin{array}{l}\text { pump } \\
\text { pump }\end{array}$ & $\begin{array}{l}\text { composite } \\
\text { composite }\end{array}$ & $\begin{array}{r}16-J u l-03 \\
21-O c t-98\end{array}$ \\
\hline U19v PS1ds & Almendro & 06-Jun-73 & 371453 & 1162057 & 6842 & $3837^{*}$ & --- & $\begin{array}{l}\text { Pressure } \\
\text { Tube }\end{array}$ & $2200^{*}$ & bailer & $3089^{*}$ & 23-Jul-03 \\
\hline $\begin{array}{l}\text { U19v PS1ds } \\
\text { U19v PS1ds } \\
\text { U19v PS1ds }\end{array}$ & $\begin{array}{l}\text { Almendro } \\
\text { Almendro } \\
\text { Almendro }\end{array}$ & $\begin{array}{l}\text { 06-Jun-73 } \\
06-J u n-73 \\
\text { 06-Jun-73 }\end{array}$ & $\begin{array}{lll}37 & 14 & 53 \\
37 & 14 & 53 \\
37 & 14 & 53\end{array}$ & $\begin{array}{l}1162057 \\
1162057 \\
1162057\end{array}$ & $\begin{array}{l}6842 \\
6842 \\
6842\end{array}$ & $\begin{array}{l}3837^{*} \\
3837^{*} \\
3837^{*}\end{array}$ & $\begin{array}{l}--- \\
--- \\
---\end{array}$ & --- & $\begin{array}{l}2187^{\star} \\
2170^{\star} \\
2170^{\star}\end{array}$ & $\begin{array}{l}\text { bailer } \\
\text { bailer } \\
\text { bailer }\end{array}$ & $\begin{array}{l}3089^{\star} \\
3089^{\star} \\
2999^{\star}\end{array}$ & $\begin{array}{l}\text { 31-May-01 } \\
26-S e p-00 \\
18-A u g-99\end{array}$ \\
\hline ER-20-5 \#3 & Tybo & 14-May-75 & 371311 & 1162838 & 6242 & 4294 & $3430-3882$ & --- & 2060 & pump & composite & 15-Nov-01 \\
\hline
\end{tabular}

* well depth, water depth, and sampling depth are corrected for borehole slant assuming vertical depth = slant depth $\times 0.936$.

† data are not corrected for borehole slant 
Table 2. Water chemistry and anion concentrations.

\begin{tabular}{|c|c|c|c|c|c|c|c|c|c|c|c|}
\hline Well name & Test & Sample date & $\mathrm{pH}$ & $\begin{array}{c}\mathrm{T} \\
\left({ }^{\circ} \mathrm{C}\right)\end{array}$ & $\begin{array}{l}\text { Cond. } \\
(\mu \mathrm{S} / \mathrm{cm})\end{array}$ & $\begin{array}{l}\mathrm{TDIC} \mathrm{as}_{\mathrm{HCO}_{3}^{-}} \\
\text {(mg/L) }\end{array}$ & $\begin{array}{c}\mathrm{F} \\
(\mathrm{mg} / \mathrm{L})\end{array}$ & $\begin{array}{c}\mathrm{Cl} \\
(\mathrm{mg} / \mathrm{L})\end{array}$ & $\begin{array}{c}\mathrm{Br} \\
(\mathrm{mg} / \mathrm{L})\end{array}$ & $\begin{array}{c}\mathrm{NO}_{3} \\
(\mathrm{mg} / \mathrm{L})\end{array}$ & $\begin{array}{c}\mathrm{SO}_{4} \\
(\mathrm{mg} / \mathrm{L})\end{array}$ \\
\hline \multicolumn{12}{|c|}{ Hot Wells - Frenchman Flat } \\
\hline $\begin{array}{l}\text { UE5n } \\
\text { UE5n }\end{array}$ & $\begin{array}{l}\text { Cambric } \\
\text { Cambric }\end{array}$ & $\begin{array}{l}\text { 19-Apr-01 } \\
\text { 09-Sep-99 }\end{array}$ & $\begin{array}{l}8.7 \\
8.4\end{array}$ & $\begin{array}{l}23.0 \\
26.5\end{array}$ & $\begin{array}{l}408 \\
453\end{array}$ & $\begin{array}{l}162 \\
183\end{array}$ & $\begin{array}{l}0.7 \\
0.8\end{array}$ & $\begin{array}{l}12.9 \\
12.0\end{array}$ & $\begin{array}{l}<0.1 \\
<0.03\end{array}$ & $\begin{array}{l}6.7 \\
8.1\end{array}$ & $\begin{array}{l}32.0 \\
31.8\end{array}$ \\
\hline RNM-1 & Cambric & 28-Jun-00 & 8.0 & 26.0 & 416 & --- & 0.3 & 12.3 & 0.2 & 16.2 & 36.5 \\
\hline $\begin{array}{l}\text { RNM-2S } \\
\text { RNM-2S } \\
\text { RNM-2S } \\
\text { RNM-2S }\end{array}$ & $\begin{array}{l}\text { Cambric } \\
\text { Cambric } \\
\text { Cambric } \\
\text { Cambric }\end{array}$ & $\begin{array}{c}\text { 10-Jul-03 } \\
09-M a y-03 \\
14-J u n-00 \\
11-O c t-99\end{array}$ & $\begin{array}{c}8.0 \\
8.2 \\
7.8^{*} \\
8.2\end{array}$ & $\begin{array}{c}24.4 \\
24.0 \\
--- \\
24.6\end{array}$ & $\begin{array}{c}418 \\
450 \\
429^{\star} \\
440\end{array}$ & $\begin{array}{l}168 \\
152 \\
130 \\
168\end{array}$ & $\begin{array}{l}0.5 \\
0.5 \\
0.4 \\
0.6\end{array}$ & $\begin{array}{l}13.5 \\
13.6 \\
14.8 \\
13.7\end{array}$ & $\begin{array}{c}0.6 \\
0.6 \\
0.2 \\
<0.03\end{array}$ & $\begin{array}{l}12.6 \\
12.5 \\
14.3 \\
13.9\end{array}$ & $\begin{array}{l}38.0 \\
38.0 \\
36.8 \\
37.0\end{array}$ \\
\hline \multicolumn{12}{|c|}{ Hot Wells - Yucca Flat } \\
\hline U4u PS2a & Dalhart & 16-Aug-99 & $8.2^{*}$ & --- & $352^{*}$ & 160 & 0.7 & 5.8 & $<0.03$ & 18.5 & 12.0 \\
\hline UE-7ns & Bourbon & 21-Aug-01 & $8.0^{*}$ & --- & $375^{\star}$ & 166 & 0.8 & 22.9 & $<0.1$ & $<0.09$ & 1.6 \\
\hline UE-2ce & Nash & 22-Aug-01 & $7.9^{*}$ & --- & $435^{\star}$ & 308 & 0.3 & 15.5 & $<0.1$ & $<0.09$ & 11.1 \\
\hline $\begin{array}{l}\text { U-3cn PS\#2 } \\
\text { Hot Wells - Pahute }\end{array}$ & Bilby & 18-Dec-01 & $8.1^{*}$ & --- & $490^{*}$ & 287 & 0.8 & 8.6 & 0.57 & 5.8 & 20.3 \\
\hline $\begin{array}{l}\text { U20n PS1 DDh } \\
\text { U20n PS1 DDh }\end{array}$ & $\begin{array}{l}\text { Cheshire } \\
\text { Cheshire }\end{array}$ & $\begin{array}{l}\text { 09-Jul-03 } \\
\text { 12-Oct-99 }\end{array}$ & $\begin{array}{l}8.5 \\
8.2\end{array}$ & $\begin{array}{l}38.4 \\
38.2\end{array}$ & $\begin{array}{l}330 \\
324\end{array}$ & $\begin{array}{c}90 \\
108\end{array}$ & $\begin{array}{l}3.6 \\
3.6\end{array}$ & $\begin{array}{l}10.9 \\
11.1\end{array}$ & $\begin{array}{c}0.6 \\
<0.03\end{array}$ & $\begin{array}{l}1.9 \\
2.3\end{array}$ & $\begin{array}{l}27.9 \\
28.2\end{array}$ \\
\hline $\begin{array}{l}\text { U19q PS1d } \\
\text { U19q PS1d }\end{array}$ & $\begin{array}{l}\text { Camembert } \\
\text { Camembert }\end{array}$ & $\begin{array}{l}16-J u l-03 \\
21-O c t-98\end{array}$ & $\begin{array}{l}8.0 \\
7.2\end{array}$ & $\begin{array}{l}35.2 \\
33.0\end{array}$ & $\begin{array}{l}416 \\
959\end{array}$ & $\begin{array}{c}496 \\
1016\end{array}$ & $\begin{array}{l}15.5 \\
31.5\end{array}$ & $\begin{array}{c}7.2 \\
10.4\end{array}$ & $\begin{array}{l}<0.03 \\
<0.1\end{array}$ & $\begin{array}{c}0.5 \\
<0.07\end{array}$ & $\begin{array}{l}20.8 \\
29.7\end{array}$ \\
\hline $\begin{array}{l}\text { U19v PS1ds } \\
\text { U19v PS1ds } \\
\text { U19v PS1ds } \\
\text { U19v PS1ds }\end{array}$ & $\begin{array}{l}\text { Almendro } \\
\text { Almendro } \\
\text { Almendro } \\
\text { Almendro }\end{array}$ & $\begin{array}{c}\text { 23-Jul-03 } \\
\text { 31-May-01 } \\
\text { 26-Sep-00 } \\
\text { 18-Aug-99 }\end{array}$ & $\begin{array}{c}9.3 \\
--- \\
9.3^{*} \\
8.2^{*}\end{array}$ & $\begin{array}{c}35.7 \\
--- \\
-- \\
---\end{array}$ & $\begin{array}{c}517 \\
--- \\
742^{*} \\
728^{*}\end{array}$ & $\begin{array}{l}207 \\
250 \\
262 \\
120\end{array}$ & $\begin{array}{l}8.9 \\
9.7 \\
9.5 \\
9.9\end{array}$ & $\begin{array}{l}53.2 \\
66.5 \\
48.2 \\
40.5\end{array}$ & $\begin{array}{l}0.05 \\
<0.1 \\
<0.1 \\
<0.03\end{array}$ & $\begin{array}{c}0.7 \\
<0.09 \\
<0.09 \\
<0.02\end{array}$ & $\begin{array}{l}0.8 \\
2.5 \\
3.8 \\
3.9\end{array}$ \\
\hline ER-20-5 \#3 & Tybo/Benham & 15-Nov-01 & $8.0^{*}$ & --- & $345^{*}$ & 110 & 3.6 & 18.9 & 0.76 & 2.6 & 35.3 \\
\hline
\end{tabular}

A dashed line indicates that no measurement was recorded for the listed parameter.

Cond. = Conductivity; Asterisks $\left(^{*}\right)$ and $\mathrm{pH}$ and conductivity data indicate measurements taken in the laboratory. 
Table 3. Major ion chemistry and trace element data. Note that concentrations are listed in units of milligrams, micrograms, or picograms.

\begin{tabular}{|c|c|c|c|c|c|c|c|c|c|c|c|c|c|c|c|c|c|c|c|c|c|}
\hline Well name & Test & Sample date & $\begin{array}{c}\mathrm{Na} \\
(\mathrm{mg} / \mathrm{L})\end{array}$ & $\begin{array}{c}\mathrm{K} \\
(\mathrm{mg} / \mathrm{L})\end{array}$ & $\begin{array}{c}\mathrm{Ca} \\
(\mathrm{mg} / \mathrm{L})\end{array}$ & $\begin{array}{c}\mathrm{Mg} \\
(\mathrm{mg} / \mathrm{L})\end{array}$ & $\begin{array}{c}\mathrm{Al} \\
(\mathrm{mg} / \mathrm{L}) \\
\end{array}$ & $\begin{array}{c}\text { As } \\
(\mu \mathrm{g} / \mathrm{L})\end{array}$ & $\begin{array}{c}\text { B } \\
\text { (mg/L) }\end{array}$ & $\begin{array}{c}\mathrm{Ba} \\
(\mathrm{mg} / \mathrm{L})\end{array}$ & $\begin{array}{c}\mathrm{Fe} \\
(\mathrm{mg} / \mathrm{L})\end{array}$ & $\begin{array}{c}\text { I } \\
(\mu \mathrm{g} / \mathrm{L})\end{array}$ & $\begin{array}{c}\text { Li } \\
\text { (mg/L) }\end{array}$ & $\begin{array}{c}M n \\
(\mu \mathrm{g} / \mathrm{L})\end{array}$ & $\begin{array}{c}\text { Mo } \\
(\mu \mathrm{g} / \mathrm{L}) \\
\end{array}$ & $\begin{array}{c}\mathrm{Pb} \\
(\mu \mathrm{g} / \mathrm{L})\end{array}$ & $\begin{array}{c}\mathrm{Pu} \\
\text { (pg/L) }\end{array}$ & $\begin{array}{c}\text { Se } \\
(\mu \mathrm{g} / \mathrm{L})\end{array}$ & $\begin{array}{c}\mathrm{Si} \\
(\mathrm{mg} / \mathrm{L})\end{array}$ & $\begin{array}{c}\mathrm{Sr} \\
(\mu \mathrm{g} / \mathrm{L})\end{array}$ & $\begin{array}{c}\mathbf{U} \\
(\mu \mathrm{g} / \mathrm{L})\end{array}$ \\
\hline \multicolumn{22}{|c|}{ Hot Wells - Frenchman Flat } \\
\hline $\begin{array}{l}\text { UE5n } \\
\text { UE5n }\end{array}$ & $\begin{array}{l}\text { Cambric } \\
\text { Cambric }\end{array}$ & $\begin{array}{l}\text { 19-Apr-01 } \\
\text { 09-Sep-99 }\end{array}$ & $\begin{array}{l}76 \\
86\end{array}$ & $\begin{array}{l}8.0 \\
8.0\end{array}$ & $\begin{array}{l}8.6 \\
7.5\end{array}$ & $\begin{array}{l}2.0 \\
2.0\end{array}$ & $\begin{array}{l}<0.05 \\
<0.02\end{array}$ & $\begin{array}{c}22 \\
9\end{array}$ & $\overline{0.34}$ & $\begin{array}{c}0.021 \\
<0.005\end{array}$ & $\begin{array}{l}<0.04 \\
0.06\end{array}$ & --- & $\begin{array}{c}0.02 \\
<0.05\end{array}$ & $\begin{array}{l}<6 \\
10\end{array}$ & $\begin{array}{l}4 \\
5\end{array}$ & $\begin{array}{c}-- \\
0.37\end{array}$ & -- & $\begin{array}{l}--- \\
<2\end{array}$ & $\begin{array}{c}27.4 \\
---\end{array}$ & $\begin{array}{l}22 \\
50\end{array}$ & $\begin{array}{c}0.41 \\
4.0\end{array}$ \\
\hline RNM-1 & Cambric & 28-Jun-00 & 44 & 8.0 & 26.0 & 9.4 & 0.37 & --- & --- & --- & 0.18 & --- & 0.03 & --- & --- & --- & --- & --- & 20 & 300 & 4.0 \\
\hline $\begin{array}{l}\text { RNM-2S } \\
\text { RNM-2S } \\
\text { RNM-2S } \\
\text { RNM-2S }\end{array}$ & $\begin{array}{l}\text { Cambric } \\
\text { Cambric } \\
\text { Cambric } \\
\text { Cambric }\end{array}$ & $\begin{array}{c}\text { 10-Jul-03 } \\
09-M a y-03 \\
14-J u n-00 \\
11-O c t-99\end{array}$ & $\begin{array}{c}56.7 \\
57.2 \\
62 \\
63\end{array}$ & $\begin{array}{l}7.8 \\
7.9 \\
9.7 \\
9.2\end{array}$ & $\begin{array}{l}15.1 \\
16.3 \\
18.0 \\
17.0\end{array}$ & $\begin{array}{l}5.7 \\
5.9 \\
5.2 \\
5.6\end{array}$ & $\begin{array}{c}<0.05 \\
<0.05 \\
0.38 \\
<0.02\end{array}$ & $\begin{array}{c}<20 \\
27 \\
--- \\
5\end{array}$ & $\begin{array}{c}0.86 \\
1.04 \\
--- \\
0.24\end{array}$ & $\begin{array}{c}0.006 \\
0.005 \\
--- \\
<0.005\end{array}$ & $\begin{array}{c}<0.04 \\
<0.04 \\
0.18 \\
0.01\end{array}$ & $\begin{array}{c}10.5 \\
10.5 \\
--- \\
11\end{array}$ & $\begin{array}{c}0.02 \\
0.02 \\
0.02 \\
<0.05\end{array}$ & $\begin{array}{l}<6 \\
<6 \\
--- \\
<2\end{array}$ & $\begin{array}{l}<3 \\
<3 \\
--- \\
3\end{array}$ & $\begin{array}{c}<14 \\
<14 \\
--- \\
0.24\end{array}$ & $\begin{array}{c}<0.2 \\
<0.2 \\
--- \\
---\end{array}$ & $\begin{array}{c}<24 \\
<24 \\
--- \\
<2\end{array}$ & $\begin{array}{c}37.2 \\
35.5 \\
35 \\
32\end{array}$ & $\begin{array}{l}102 \\
101 \\
140 \\
110\end{array}$ & $\begin{array}{c}4.91 \\
4.93 \\
5.0 \\
4.0\end{array}$ \\
\hline \multicolumn{22}{|c|}{ Hot Wells - Yucca Flat } \\
\hline U4u PS2a & Dalhart & 16-Aug-99 & 72 & 14.0 & 13.1 & 2.7 & 12 & 4 & 0.12 & 0.03 & 1.3 & 3.1 & 0.14 & 90 & $<1$ & 8.6 & 8.7 & $<1$ & 37 & 30 & 4.2 \\
\hline UE-7ns & Bourbon & 21-Aug-01 & 67.4 & 4.9 & 20.9 & 3.6 & $<0.05$ & 21 & --- & 0.077 & 0.21 & 19.4 & 0.06 & 55 & 26 & $<14$ & $<0.6$ & $<24$ & 10 & 70 & 0.04 \\
\hline U-3cn PS\#2 & Bilby & 18-Dec-01 & 98.4 & 18.3 & 14.4 & 3.3 & 0.26 & $<20$ & --- & 0.004 & 0.30 & --- & 0.045 & 78 & 3.5 & $<14$ & $<0.6$ & $<24$ & 28.7 & 24 & 10.67 \\
\hline \multicolumn{22}{|c|}{ Hot Wells - Pahute Mesa } \\
\hline $\begin{array}{l}\text { U20n PS1 DDh } \\
\text { U20n PS1 DDh }\end{array}$ & $\begin{array}{l}\text { Cheshire } \\
\text { Cheshire }\end{array}$ & $\begin{array}{l}\text { 09-Jul-03 } \\
\text { 12-Oct-99 }\end{array}$ & $\begin{array}{c}60.7 \\
65\end{array}$ & $\begin{array}{l}1.9 \\
2.2\end{array}$ & $\begin{array}{l}3.8 \\
4.7\end{array}$ & $\begin{array}{l}0.1 \\
0.1\end{array}$ & $\begin{array}{l}0.68 \\
0.07\end{array}$ & $\begin{array}{l}<20 \\
3\end{array}$ & $\begin{array}{l}0.99 \\
0.14\end{array}$ & $\begin{array}{c}0.003 \\
<0.005\end{array}$ & $\begin{array}{c}0.81 \\
1.4\end{array}$ & $\begin{array}{l}3.0 \\
13\end{array}$ & $\begin{array}{l}0.06 \\
<0.05\end{array}$ & $\begin{array}{l}170 \\
110\end{array}$ & $\begin{array}{l}9.1 \\
10\end{array}$ & $\begin{array}{l}<14 \\
0.67\end{array}$ & $\begin{array}{l}4.1 \\
7.0\end{array}$ & $\begin{array}{l}<24 \\
<2\end{array}$ & $\begin{array}{c}30.9 \\
24\end{array}$ & $\begin{array}{l}12 \\
10\end{array}$ & $\begin{array}{l}2.07 \\
2.3\end{array}$ \\
\hline $\begin{array}{l}\text { U19q PS1d } \\
\text { U19q PS1d }\end{array}$ & $\begin{array}{l}\text { Camembert } \\
\text { Camembert }\end{array}$ & $\begin{array}{l}\text { 16-Jul-03 } \\
21-O c t-98\end{array}$ & $\begin{array}{l}199 \\
342\end{array}$ & $\begin{array}{c}9.0 \\
10.3\end{array}$ & $\begin{array}{l}5.0 \\
3.2\end{array}$ & $\begin{array}{l}0.2 \\
0.0\end{array}$ & $\begin{array}{l}0.05 \\
0.07\end{array}$ & $\begin{array}{c}<20 \\
4\end{array}$ & $0 .-87$ & $\begin{array}{l}0.028 \\
<0.01\end{array}$ & $\begin{array}{l}7.3 \\
5.8\end{array}$ & $\begin{array}{l}3.9 \\
10\end{array}$ & $\begin{array}{l}0.49 \\
1.06\end{array}$ & $\begin{array}{l}800 \\
530\end{array}$ & $\begin{array}{l}18 \\
40\end{array}$ & $\begin{array}{c}31 \\
0.60\end{array}$ & $\begin{array}{c}<0.2 \\
---\end{array}$ & $\begin{array}{l}<24 \\
<3\end{array}$ & $\begin{array}{c}20.2 \\
32\end{array}$ & $\begin{array}{c}7.9 \\
<0.01\end{array}$ & $\begin{array}{l}2.61 \\
<0.5\end{array}$ \\
\hline $\begin{array}{l}\text { U19v PS1ds } \\
\text { U19v PS1ds } \\
\text { U19v PS1ds } \\
\text { U19v PS1ds }\end{array}$ & $\begin{array}{l}\text { Almendro } \\
\text { Almendro } \\
\text { Almendro } \\
\text { Almendro }\end{array}$ & $\begin{array}{l}\text { 23-Jul-03 } \\
\text { 31-May-01 } \\
\text { 26-Sep-00 } \\
\text { 18-Aug-99 }\end{array}$ & $\begin{array}{l}140 \\
173 \\
131 \\
162\end{array}$ & $\begin{array}{c}8.8 \\
14.0 \\
11.6 \\
9.8\end{array}$ & $\begin{array}{l}1.0 \\
1.5 \\
0.7 \\
0.9\end{array}$ & $\begin{array}{l}0.1 \\
0.2 \\
0.1 \\
0.2\end{array}$ & $\begin{array}{l}0.55 \\
0.29 \\
0.25 \\
0.52\end{array}$ & $\begin{array}{c}1300 \\
140 \\
50 \\
1716\end{array}$ & $\begin{array}{c}--- \\
--- \\
--- \\
1.54\end{array}$ & $\begin{array}{l}0.06 \\
0.06 \\
0.02 \\
0.07\end{array}$ & $\begin{array}{c}10.6 \\
3.7 \\
0.19 \\
12.0\end{array}$ & $\begin{array}{l}7.5 \\
8.5 \\
7.4 \\
1.7\end{array}$ & $\begin{array}{l}0.17 \\
0.28 \\
0.24 \\
0.42\end{array}$ & $\begin{array}{c}160 \\
330 \\
--- \\
250\end{array}$ & $\begin{array}{l}1100 \\
1200 \\
1100 \\
1226\end{array}$ & $\begin{array}{c}82 \\
250 \\
22 \\
63\end{array}$ & $\begin{array}{c}<0.2 \\
2.1 \\
--- \\
58.2\end{array}$ & $\begin{array}{l}<24 \\
<24 \\
<24 \\
8\end{array}$ & $\begin{array}{c}9.6 \\
2.0 \\
6.6 \\
11\end{array}$ & $\begin{array}{l}18 \\
44 \\
-- \\
40\end{array}$ & $\begin{array}{l}0.11 \\
0.03 \\
0.02 \\
<0.5\end{array}$ \\
\hline ER-20-5 \#3 & $\begin{array}{c}\text { Tybo/ } \\
\text { Benham }\end{array}$ & 15-Nov-01 & 87.1 & 3.3 & 4.4 & 0.1 & 3.6 & 23 & --- & 0.017 & 1.9 & $<1$ & 0.07 & 75 & 5.8 & $<14$ & $<0.6$ & $<24$ & 29 & 31 & 12.80 \\
\hline
\end{tabular}

A dashed line indicates that no measurement was recorded for the listed parameter. 
Table 4. Stable isotope and noble gas data.

\begin{tabular}{|c|c|c|c|c|c|c|c|c|c|c|c|c|c|c|}
\hline Well name & Test & $\begin{array}{l}\text { Sample } \\
\text { date }\end{array}$ & $\begin{array}{c}\delta D_{\text {smow }} \\
(\%)\end{array}$ & $\begin{array}{c}\delta^{18} \mathrm{O}_{\text {smow }} \\
(\%)\end{array}$ & $\begin{array}{c}\delta^{13} \mathrm{C}_{\mathrm{PDB}} \\
(\%)\end{array}$ & $\begin{array}{c}{ }^{3} \mathrm{He} \\
\text { (atoms/g) }\end{array}$ & $\begin{array}{c}{ }^{4} \mathrm{He} \\
\text { (atoms/g) }\end{array}$ & $\begin{array}{c}\text { R/R } \mathbf{R}_{\mathbf{a}} \\
\left(\left.^{3} \mathrm{He}\right|^{4} \mathrm{He}\right. \\
\text { sample/air) }\end{array}$ & $\begin{array}{l}{ }^{20} \mathrm{Ne} \\
\text { (atoms/g) }\end{array}$ & $\begin{array}{l}{ }^{40} \mathrm{Ar} \\
\text { (atoms/g) }\end{array}$ & $\begin{array}{c}\mathrm{Kr} \\
\text { (atoms/g) }\end{array}$ & $\begin{array}{l}{ }^{130} \mathrm{Xe} \\
\text { (atoms/g) }\end{array}$ & $\begin{array}{c}\left.{ }^{87} \mathrm{Sr}\right|^{86} \mathrm{Sr} \\
\text { (ratio) }\end{array}$ & $\begin{array}{l}\delta^{87} \mathrm{Sr} \\
(\%)\end{array}$ \\
\hline \multicolumn{15}{|c|}{ Hot Wells - Frenchman Flat } \\
\hline $\begin{array}{l}\text { UE5n } \\
\text { UE5n }\end{array}$ & $\begin{array}{l}\text { Cambric } \\
\text { Cambric }\end{array}$ & $\begin{array}{l}\text { 19-Apr-01 } \\
\text { 09-Sep-99 }\end{array}$ & $\begin{array}{l}-105 \\
-106\end{array}$ & $\begin{array}{l}-13.4 \\
-13.4\end{array}$ & $\begin{array}{l}-6.7 \\
-8.3\end{array}$ & $\begin{array}{l}2.70 \mathrm{E}+09 \\
1.95 \mathrm{E}+09\end{array}$ & $\begin{array}{l}2.34 \mathrm{E}+12 \\
3.16 \mathrm{E}+12\end{array}$ & $\begin{array}{l}8.36 \mathrm{E}+02 \\
4.48 \mathrm{E}+02\end{array}$ & $\begin{array}{l}4.66 \mathrm{E}+12 \\
7.25 \mathrm{E}+12\end{array}$ & $\begin{array}{l}8.30 \mathrm{E}+15 \\
1.04 \mathrm{E}+16\end{array}$ & $\begin{array}{l}--- \\
---\end{array}$ & $\begin{array}{l}4.22 \mathrm{E}+10 \\
4.42 \mathrm{E}+10\end{array}$ & $\begin{array}{c}0.71039 \\
---\end{array}$ & $\begin{array}{c}1.68 \\
---\end{array}$ \\
\hline RNM-1 & Cambric & 28-Jun-00 & -104 & -12.7 & --- & $1.43 E+09$ & $2.05 \mathrm{E}+12$ & $5.05 E+02$ & $4.15 \mathrm{E}+12$ & $7.63 \mathrm{E}+15$ & --- & --- & --- & --- \\
\hline $\begin{array}{l}\text { RNM-2S } \\
\text { RNM-2S } \\
\text { RNM-2S } \\
\text { RNM-2S }\end{array}$ & $\begin{array}{l}\text { Cambric } \\
\text { Cambric } \\
\text { Cambric } \\
\text { Cambric }\end{array}$ & $\begin{array}{c}10-J u l-03 \\
09-M a y-03 \\
14-J u n-00 \\
11-O c t-99\end{array}$ & $\begin{array}{l}-105 \\
-105 \\
-105 \\
-104\end{array}$ & $\begin{array}{l}-13.1 \\
-13.1 \\
-13.0 \\
-12.9\end{array}$ & $\begin{array}{l}-9.5 \\
-8.2 \\
-5.3 \\
-9.3\end{array}$ & $\begin{array}{l}4.29 \mathrm{E}+10 \\
2.53 \mathrm{E}+10 \\
2.50 \mathrm{E}+10 \\
2.35 \mathrm{E}+10\end{array}$ & $\begin{array}{l}1.94 \mathrm{E}+13 \\
2.77 \mathrm{E}+12 \\
6.43 \mathrm{E}+12 \\
6.40 \mathrm{E}+12\end{array}$ & $\begin{array}{l}1.60 \mathrm{E}+03 \\
6.62 \mathrm{E}+03 \\
2.84 \mathrm{E}+03 \\
2.65 \mathrm{E}+03\end{array}$ & $\begin{array}{l}7.17 \mathrm{E}+13 \\
3.34 \mathrm{E}+12 \\
5.50 \mathrm{E}+12 \\
4.35 \mathrm{E}+12\end{array}$ & $\begin{array}{c}--- \\
--- \\
9.11 \mathrm{E}+15 \\
8.09 \mathrm{E}+15\end{array}$ & $\begin{array}{l}--- \\
--- \\
--- \\
---\end{array}$ & $\begin{array}{c}3.63 \mathrm{E}+10 \\
1.35 \mathrm{E}+10 \\
--- \\
---\end{array}$ & $\begin{array}{c}0.71049 \\
0.71051 \\
--- \\
---\end{array}$ & $\begin{array}{c}1.82 \\
1.85 \\
--- \\
---\end{array}$ \\
\hline \multicolumn{15}{|c|}{ Hot Wells - Yucca Flat } \\
\hline U4u PS2a & Dalhart & 16-Aug-99 & -100 & -12.8 & -8.7 & --- & --- & --- & --- & --- & --- & --- & --- & --- \\
\hline UE-7ns & Bourbon & 21-Aug-01 & -106 & -14.0 & -2.0 & $1.93 E+10$ & $2.45 \mathrm{E}+12$ & $5.71 \mathrm{E}+03$ & $6.52 \mathrm{E}+12$ & $9.30 \mathrm{E}+15$ & --- & $4.08 \mathrm{E}+10$ & --- & --- \\
\hline UE-2ce & Nash & 22-Aug-01 & -100 & -12.9 & -5.3 & $4.78 \mathrm{E}+09$ & $2.36 \mathrm{E}+12$ & $1.47 E+03$ & $7.14 \mathrm{E}+12$ & $9.31 \mathrm{E}+15$ & --- & $4.06 \mathrm{E}+10$ & --- & --- \\
\hline $\begin{array}{l}\text { U-3cn PS\#2 } \\
\text { Hot Wells - Pahute }\end{array}$ & $\begin{array}{l}\text { Bilby } \\
\text { Mesa }\end{array}$ & 18-Dec-01 & -108 & -13.9 & -3.8 & $5.98 \mathrm{E}+11$ & $3.59 \mathrm{E}+12$ & $1.21 \mathrm{E}+05$ & $7.41 \mathrm{E}+12$ & $9.30 \mathrm{E}+15$ & --- & $3.73 \mathrm{E}+10$ & 0.70974 & 0.76 \\
\hline $\begin{array}{l}\text { U20n PS1 DDh } \\
\text { U20n PS1 DDh }\end{array}$ & $\begin{array}{l}\text { Cheshire } \\
\text { Cheshire }\end{array}$ & $\begin{array}{l}\text { 09-Jul-03 } \\
\text { 12-Oct-99 }\end{array}$ & $\begin{array}{l}-113.5 \\
-113\end{array}$ & $\begin{array}{l}-15.0 \\
-15.0\end{array}$ & $\begin{array}{l}-4.0 \\
-6.0\end{array}$ & $\begin{array}{l}2.12 \mathrm{E}+12 \\
2.01 \mathrm{E}+12\end{array}$ & $\begin{array}{l}1.02 \mathrm{E}+13 \\
1.01 \mathrm{E}+13\end{array}$ & $\begin{array}{l}1.51 \mathrm{E}+05 \\
1.44 \mathrm{E}+05\end{array}$ & $\begin{array}{l}5.63 \mathrm{E}+12 \\
5.70 \mathrm{E}+12\end{array}$ & 6.45E+15 & --- & $\begin{array}{c}1.24 \mathrm{E}+10 \\
---\end{array}$ & $\begin{array}{l}0.71088 \\
0.71078\end{array}$ & $\begin{array}{l}2.37 \\
2.23\end{array}$ \\
\hline $\begin{array}{l}\text { U19q PS1d } \\
\text { U19q PS1d }\end{array}$ & $\begin{array}{l}\text { Camembert } \\
\text { Camembert }\end{array}$ & $\begin{array}{l}16-J u l-03 \\
21-O c t-98\end{array}$ & $\begin{array}{l}-114 \\
-113\end{array}$ & $\begin{array}{l}-15.0 \\
-14.6\end{array}$ & $\begin{array}{l}+0.5 \\
+1.5\end{array}$ & $2.02 \bar{E}+12$ & $1.85 \bar{E}+14$ & $7.90 \mathrm{E}+03$ & 7.73E+12 & --- & --- & $\begin{array}{l}--- \\
---\end{array}$ & $\begin{array}{l}0.71190 \\
0.71260\end{array}$ & $\begin{array}{l}3.81 \\
4.79\end{array}$ \\
\hline $\begin{array}{l}\text { U19v PS1ds } \\
\text { U19v PS1ds } \\
\text { U19v PS1ds } \\
\text { U19v PS1ds }\end{array}$ & $\begin{array}{l}\text { Almendro } \\
\text { Almendro } \\
\text { Almendro } \\
\text { Almendro }\end{array}$ & $\begin{array}{c}23-J u l-03 \\
31-M a y-01 \\
26-S e p-00 \\
18-A u g-99\end{array}$ & $\begin{array}{l}-112 \\
-112 \\
-111 \\
-111\end{array}$ & $\begin{array}{l}-13.4 \\
-13.3 \\
-13.4 \\
-13.4\end{array}$ & $\begin{array}{l}+35.4 \\
+30.1 \\
+30.2 \\
+45.0\end{array}$ & $\begin{array}{c}7.64 \mathrm{E}+10 \\
3.75 \mathrm{E}+11 \\
--- \\
---\end{array}$ & $\begin{array}{c}9.52 \mathrm{E}+11 \\
1.50 \mathrm{E}+12 \\
--- \\
---\end{array}$ & $\begin{array}{c}5.82 \mathrm{E}+04 \\
1.81 \mathrm{E}+05 \\
--- \\
---\end{array}$ & $\begin{array}{c}5.74 \mathrm{E}+12 \\
4.42 \mathrm{E}+12 \\
--- \\
---\end{array}$ & $\begin{array}{c}--- \\
1.45 \mathrm{E}+16 \\
--- \\
---\end{array}$ & $\begin{array}{l}--- \\
--- \\
--- \\
---\end{array}$ & $\begin{array}{c}1.69 \mathrm{E}+10 \\
8.13 \mathrm{E}+10 \\
--- \\
---\end{array}$ & $\begin{array}{c}0.71113 \\
--- \\
--- \\
---\end{array}$ & $\begin{array}{c}2.72 \\
--- \\
-- \\
--\end{array}$ \\
\hline ER-20-5 \#3 & $\begin{array}{c}\text { Tybo/ } \\
\text { Benham }\end{array}$ & 15-Nov-01 & -114 & -15.0 & -4.0 & $8.09 E+09$ & $7.48 \mathrm{E}+12$ & $7.84 \mathrm{E}+02$ & $7.49 \mathrm{E}+12$ & --- & --- & $4.20 \mathrm{E}+10$ & 0.70864 & -0.79 \\
\hline
\end{tabular}

A dashed line indicates that no measurement was recorded for the listed parameter. 
Table 5. Radiochemical data.

\begin{tabular}{|c|c|c|c|c|c|c|c|c|c|c|}
\hline Well name & Test & Sample date & ${ }^{3} \mathrm{H}$ & ${ }^{3} \mathrm{H}$ & ${ }^{14} \mathrm{C}$ & ${ }^{14} \mathrm{C}$ & ${ }^{36} \mathrm{Cl} / \mathrm{Cl}$ & ${ }^{36} \mathrm{Cl}$ & ${ }^{85} \mathrm{Kr}$ & ${ }^{99} \mathrm{Tc}$ \\
\hline Unit & & (date & (pCi/L) & (pCi/L) & (pmc) & (pCi/L) & (ratio) & (pCi/L) & (pCi/L) & (pCi/L) \\
\hline Half-life (a) & & collected & 12.32 & 12.32 & 5730 & 5730 & & $3.01 E+05$ & 10.73 & $2.13 E+05$ \\
\hline Ref. date & & in field) & collect. & time zero & collect. & collect. & & collect. & collect. & collect. \\
\hline \multicolumn{11}{|c|}{ Hot Wells - Frenchman Flat } \\
\hline UE5n & Cambric & 19-Apr-01 & $1.4 \mathrm{E}+05$ & $1.1 \mathrm{E}+06$ & $2.84 \mathrm{E}+01$ & 5.53E-02 & $5.38 \mathrm{E}-10$ & $2.29 \mathrm{E}-01$ & --- & --- \\
\hline UE5n & Cambric & 09-Sep-99 & -- & --- & $1.88 \mathrm{E}+01$ & 4.14E-02 & $6.01 \mathrm{E}-10$ & $2.38 \mathrm{E}-01$ & $<40$ & $2.29 \mathrm{E}-03$ \\
\hline RNM-1 & Cambric & 28-Jun-00 & $2.8 \mathrm{E}+04$ & $2.1 \mathrm{E}+05$ & -- & --- & 1.06E-12 & 4.30E-04 & --- & --- \\
\hline RNM-2S & Cambric & 10-Jul-03 & $1.5 \mathrm{E}+05$ & $1.3 \mathrm{E}+06$ & $3.64 \mathrm{E}+02$ & 7.35E-01 & $2.30 \mathrm{E}-10$ & 1.03E-01 & --- & --- \\
\hline RNM-2S & Cambric & 09-May-03 & $1.5 \mathrm{E}+05$ & $1.3 \mathrm{E}+06$ & $3.87 \mathrm{E}+02$ & 7.07E-01 & $2.55 \mathrm{E}-10$ & 1.15E-01 & --- & --- \\
\hline RNM-2S & Cambric & 14-Jun-00 & $1.9 \mathrm{E}+05$ & $1.4 \mathrm{E}+06$ & --- & --- & $1.62 \mathrm{E}-10$ & 7.92E-02 & --- & --- \\
\hline RNM-2S & Cambric & 11-Oct-99 & $2.3 \mathrm{E}+05$ & $1.6 \mathrm{E}+06$ & $4.13 \mathrm{E}+02$ & 8.34E-01 & $1.64 \mathrm{E}-10$ & 7.40E-02 & $<40$ & $9.72 \mathrm{E}-04$ \\
\hline \multicolumn{11}{|c|}{ Hot Wells - Yucca Flat } \\
\hline U4u PS2a & Dalhart & 16-Aug-99 & $1.6 \mathrm{E}+07$ & $3.1 \mathrm{E}+07$ & $1.19 \mathrm{E}+05$ & $2.29 \mathrm{E}+02$ & 4.45E-08 & $8.52 E+00$ & --- & --- \\
\hline UE-7ns & Bourbon & 21-Aug-01 & $4.6 \mathrm{E}+03$ & $3.2 \mathrm{E}+04$ & $6.97 \mathrm{E}+01$ & 1.39E-01 & $1.85 \mathrm{E}-12$ & $1.40 \mathrm{E}-03$ & --- & --- \\
\hline UE-2ce & Nash & 22-Aug-01 & $1.4 \mathrm{E}+05$ & $9.9 \mathrm{E}+05$ & 2.17E+02 & 8.01E-01 & $1.62 \mathrm{E}-09$ & 8.27E-01 & --- & --- \\
\hline U-3cn PS\#2 & Bilby & 18-Dec-01 & $9.9 \mathrm{E}+06$ & $8.6 \mathrm{E}+07$ & $8.78 \mathrm{E}+04$ & $3.03 E+02$ & $1.52 \mathrm{E}-07$ & $4.32 \mathrm{E}+01$ & --- & --- \\
\hline \multicolumn{11}{|c|}{ Hot Wells - Pahute Mesa } \\
\hline U20n PS1 DDh & Cheshire & 09-Jul-03 & $3.9 \mathrm{E}+07$ & $1.8 \mathrm{E}+08$ & $1.69 \mathrm{E}+05$ & $1.83 \mathrm{E}+02$ & 2.22E-09 & 7.99E-01 & -- & --- \\
\hline U20n PS1 DDh & Cheshire & 12-Oct-99 & $5.1 \mathrm{E}+07$ & $1.9 \mathrm{E}+08$ & $1.54 \mathrm{E}+05$ & $2.00 \mathrm{E}+02$ & 1.15E-09 & $4.20 \mathrm{E}-01$ & 2.77E+04 & $2.20 \mathrm{E}+01$ \\
\hline U19q PS1d & Camembert & 16-Jul-03 & $1.1 \mathrm{E}+07$ & $5.4 \mathrm{E}+07$ & $4.92 \mathrm{E}+04$ & $2.93 \mathrm{E}+02$ & 7.73E-11 & $1.84 \mathrm{E}-02$ & --- & -- \\
\hline U19q PS1d & Camembert & 21-Oct-98 & $2.1 \mathrm{E}+07$ & $7.8 \mathrm{E}+07$ & $1.07 \mathrm{E}+05$ & $1.31 \mathrm{E}+03$ & $5.28 \mathrm{E}-11$ & $1.81 \mathrm{E}-02$ & $1.10 \mathrm{E}+05$ & $8.40 \mathrm{E}-02$ \\
\hline U19v PS1ds & Almendro & 23-Jul-03 & 1.1E+08 & $6.2 E+08$ & $2.99 E+04$ & $7.44 \mathrm{E}+01$ & $3.20 \mathrm{E}-09$ & $5.62 \mathrm{E}+00$ & --- & --- \\
\hline U19v PS1ds & Almendro & 31-May-01 & $1.8 \mathrm{E}+08$ & $9.0 \mathrm{E}+08$ & $3.11 \mathrm{E}+04$ & $9.33 \mathrm{E}+01$ & 1.63E-09 & $3.58 \mathrm{E}+00$ & --- & --- \\
\hline U19v PS1ds & Almendro & 26-Sep-00 & $1.5 \mathrm{E}+08$ & 7.1E+08 & $3.19 \mathrm{E}+04$ & $1.01 \mathrm{E}+02$ & 2.30E-09 & $3.66 \mathrm{E}+00$ & -- & --- \\
\hline U19v PS1ds & Almendro & 18-Aug-99 & $1.6 \mathrm{E}+08$ & $6.8 \mathrm{E}+08$ & $2.47 E+04$ & $3.56 \mathrm{E}+01$ & 1.60E-09 & $2.14 \mathrm{E}+00$ & --- & --- \\
\hline ER-20-5 \#3 & $\begin{array}{c}\text { Tybo/ } \\
\text { Benham }\end{array}$ & 15-Nov-01 & $1.4 \mathrm{E}+05$ & $6.3 \mathrm{E}+05$ & $1.57 \mathrm{E}+03$ & $2.08 \mathrm{E}+00$ & $3.49 \mathrm{E}-11$ & $2.18 \mathrm{E}-02$ & --- & --- \\
\hline
\end{tabular}

A dashed line indicates that no measurement was recorded for the listed parameter. 
Table 5 con'd. Radiochemical data.

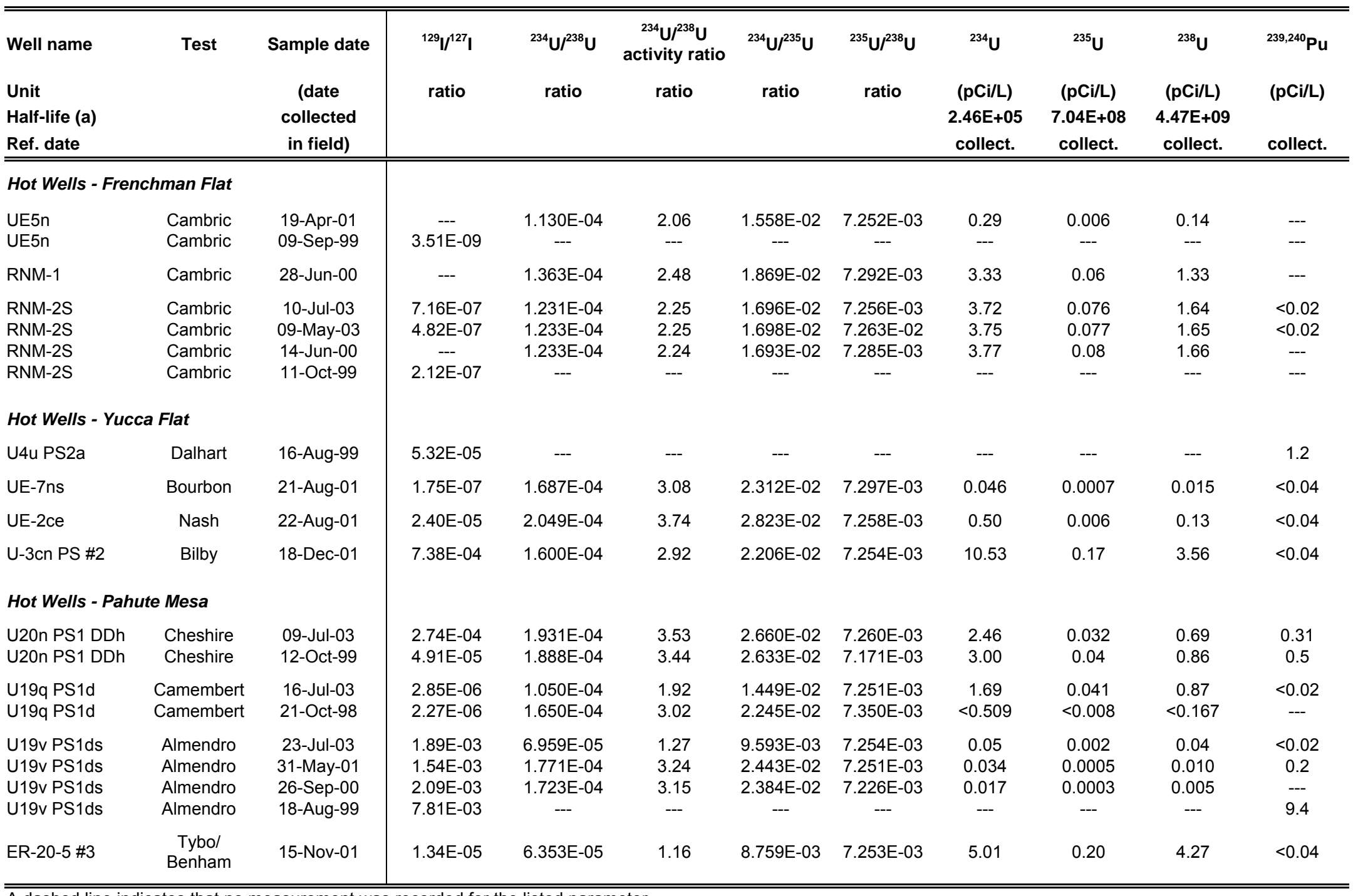

A dashed line indicates that no measurement was recorded for the listed parameter. 


\title{
Chapter 2
}

\section{FY 2003 Environmental Well Data Summary}

\author{
Timothy P. Rose, Gail F. Eaton, G. Bryant Hudson, Ross W. Williams, \\ Max Hu, Jean E. Moran, and Lennox J. Harris
}

\section{Introduction}

This report summarizes the results of chemical and isotopic analyses of groundwater samples collected from UGTA environmental monitoring wells during FY 2003. The primary technical objective of this effort is to develop a geochemical data set that can be used to independently verify groundwater flow model predictions. This effort is coordinated by the Environmental Management Program of the National Nuclear Security Administration Nevada Site Office (NNSA/NSO), and is supported by LLNL in cooperation with Los Alamos National Laboratory (LANL), the U.S. Geological Survey (USGS), Desert Research Institute (DRI), Stoller-Navarro Joint Venture (SNJV), and Bechtel Nevada (BN).

During FY 2003, groundwater characterization samples were collected from a total of thirteen environmental monitoring wells, including one new well in Frenchman Flat, four new wells in Yucca Flat, and eight pre-existing wells in the Pahute Mesa-Oasis Valley region (see Figure 1). LLNL analyzed these samples in accordance with laboratory protocols found in the Underground Test Area (UGTA) Project Standard Operating Procedures (LLNL, 2004). Well data and analytical results for environmental samples collected in FY 2003 are summarized in Tables 1 through 5 at the end of this chapter.

\section{Frenchman Flat - Well ER-5-4 \#2}

Well ER-5-4 \#2 is located in the central portion of Area 5 (Frenchman Flat), $\sim 350 \mathrm{~m} \mathrm{NE}$ of the emplacement hole for the Cambric test (U-5e), and $\sim 30 \mathrm{~m}$ south of well ER-5-4. Well completion, development, and hydraulic testing data are summarized in reports by Shaw Environmental (2003a, 2003b). ER-5-4 \#2 was completed to a total depth of $2,133.6 \mathrm{~m}(7,000 \mathrm{ft})$ in September 2002. Groundwater is produced from a slotted interval $1,977.0-2,029.3 \mathrm{~m}(6,486.3-6,657.7 \mathrm{ft})$ below the surface. This interval is completed in non-welded, partially-welded, and bedded Bullfrog Tuff (Tcb).

Groundwater characterization samples were collected from ER-5-4 \#2 on 21 November 2002. At the time of sampling, approximately $4 \times 10^{6}$ gallons of water had been pumped from the well at a rate of $\sim 125 \mathrm{gpm}$. Well ER-5-4 \#2 produces a sodium bicarbonatesulfate groundwater with a high electrical conductivity $(1249 \mu \mathrm{S} / \mathrm{cm})$, and has a higher concentration of dissolved ions than any well previously completed in the alluvial and volcanic units in Frenchman Flat. 


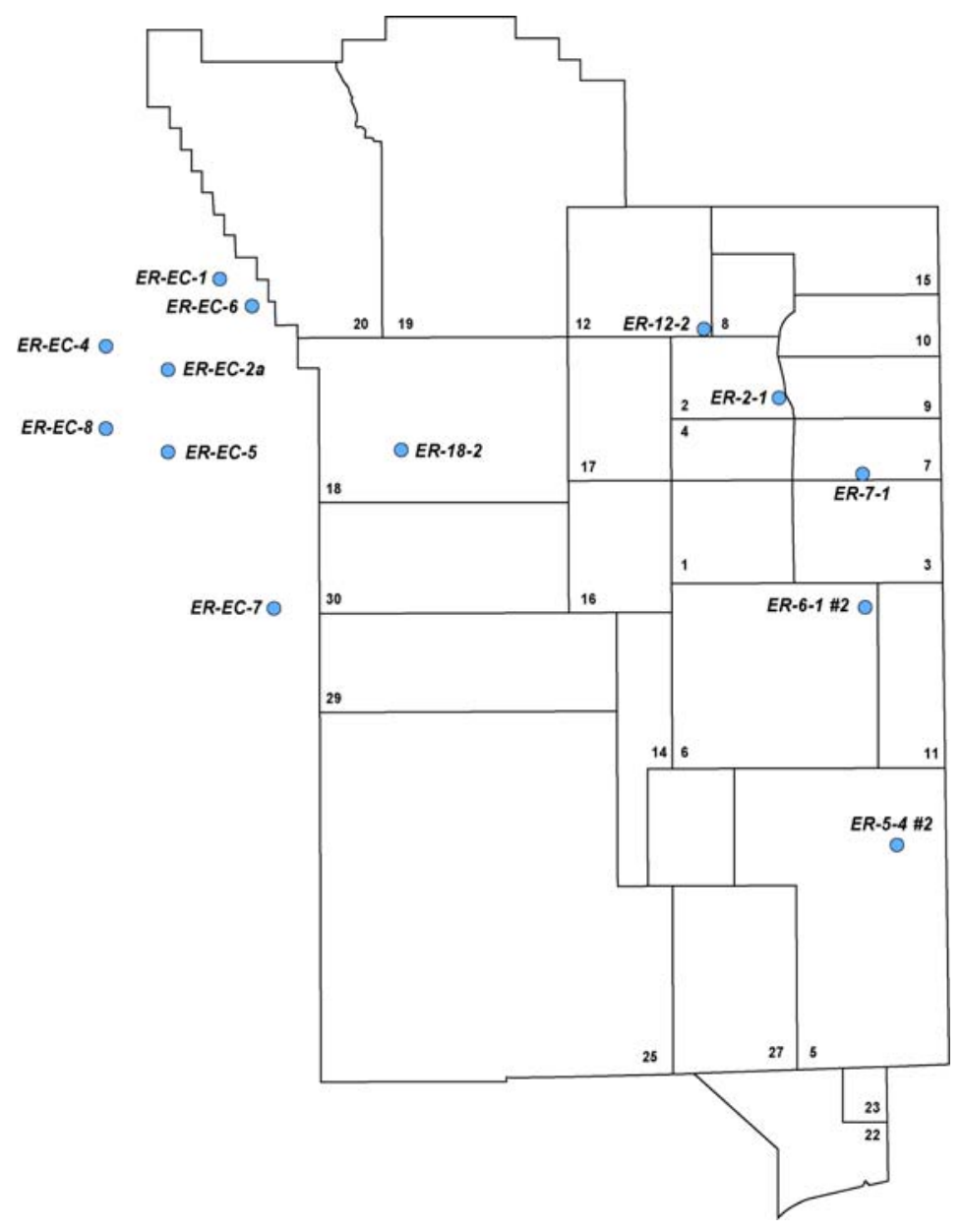

Figure 1. FY 2003 environmental well sampling locations.

Of particular note is the high concentration of dissolved fluoride $(63.9 \mathrm{mg} / \mathrm{L})$. Fluorine enrichments are widely observed in some types of rhyolitic tuffs (Christiansen et al., 1986), possibly accounting for the high fluoride concentration in the water. Stable isotope data ( $\delta \mathrm{D}$ and $\delta^{18} \mathrm{O}$ ) show ER-5-4 \#2 groundwater is isotopically depleted relative to modern precipitation in Frenchman Flat (Ingraham et al., 1991). These data suggest the groundwater may have been recharged during the last pluvial period, when the climate in southern Nevada was cooler and wetter than the present conditions.

The tritium activity in ER-5-4 \#2 groundwater was analyzed by the helium accumulation method (Surano et al., 1992). The results show the presence of detectable tritium in the water $(157 \mathrm{pCi} / \mathrm{L})$. Low-level tritium was encountered sporadically during well drilling with maximum concentrations of $<2,000 \mathrm{pCi} / \mathrm{L}$ (Shaw Environmental, 2003a). This represents one possible source of the tritium activity. However, LLNL experienced problems with low-level tritium contamination of several environmental well samples during FY 2003. The contamination may have originated from hot well samples that were stored nearby. Hence, we cannot rule out the possibility that the ER-5-4 \#2 samples were cross-contaminated with tritium after sampling (see noble gas discussion below). 
The measured ${ }^{3} \mathrm{He} /{ }^{4} \mathrm{He}$ ratio in ER-5-4 \#2 groundwater $\left(\mathrm{R}=1.23 \times 10^{-6}\right)$ is similar to that of the natural atmospheric ratio $\left(\mathrm{R}_{\mathrm{a}}=1.38 \times 10^{-6}\right)$, giving an $\mathrm{R} / \mathrm{R}_{\mathrm{a}}$ value of 0.89 . The sample contains a small but measurable amount of ${ }^{4} \mathrm{He}$ from the decay of $U$ and $\mathrm{Th}$ in the aquifer, but gives a very low model ${ }^{4} \mathrm{He}$ age of only $\sim 100$ years. The lack of ${ }^{4} \mathrm{He}$ buildup in the water is unusual given that other geochemical parameters suggest a long aquifer residence time. The estimated recharge temperature based on measured noble gas concentrations is $17^{\circ} \mathrm{C}$, and the sample contains a small amount of excess air $\left(\sim 1 \times 10^{-3}\right.$ $\mathrm{cm}^{3} / \mathrm{g}$ ). After subtracting the contribution to ${ }^{3} \mathrm{He}$ and ${ }^{4} \mathrm{He}$ from $\mathrm{U}$ and $\mathrm{Th}$ decay, the ${ }^{3} \mathrm{He} /{ }^{4} \mathrm{He}$ ratio is nearly identical to the atmospheric ${ }^{3} \mathrm{He} /{ }^{4} \mathrm{He}$ ratio, indicating that the sample contains no detectable ${ }^{3} \mathrm{He}$ from tritium decay. The detection limit for ${ }^{3} \mathrm{He}$ from ${ }^{3} \mathrm{H}$ decay suggests that the tritium content of the water in the copper tube (i.e. the noble gas sample) is less than that measured in the tritium sample by more than a factor of two. This is consistent with tritium cross-contamination after sampling.

The ${ }^{14} \mathrm{C}$ value of dissolved inorganic carbon (DIC) in ER-5-4 \#2 is 1.0 percent modern, yielding an uncorrected ${ }^{14} \mathrm{C}$ age of 38,150 years. The $\delta^{13} \mathrm{C}$ value of the DIC $(+0.2 \%$ o indicates the groundwater has equilibrated with carbonate minerals in the host rock. However, the very low $\mathrm{Ca}^{2+}$ concentration in the water suggests that calcite dissolution is coupled with $\mathrm{Na}-\mathrm{Ca}$ ion exchange reactions with other minerals in the aquifer.

ER-5-4 \#2 groundwater has a high chloride concentration $(51.7 \mathrm{mg} / \mathrm{L})$ and a ${ }^{36} \mathrm{Cl} / \mathrm{Cl}$ ratio of only $1.76 \times 10^{-13}$ (the lowest ratio of any well in Frenchman Flat). High chloride values and low ${ }^{36} \mathrm{Cl} / \mathrm{Cl}$ ratios reflect the leaching of ${ }^{36} \mathrm{Cl}$-depleted chloride in the rock, but such extreme values are normally observed only in lower carbonate aquifer groundwaters (see Figure 2, later in this chapter). As noted above, the ${ }^{13} \mathrm{C}$-enriched value of the DIC in this sample implies extensive interaction with carbonate minerals (which presumably occur along fractures in the volcanic rock). Hence, calcite dissolution-precipitation reactions are one potential mechanism for the addition of dead chloride to the water. Alternatively, the bulk composition of the volcanic host rock may have an unusual enrichment in chloride in association with its (inferred) high fluorine content.

The ${ }^{87} \mathrm{Sr} /{ }^{86} \mathrm{Sr}$ ratio in ER-5-4 \#2 groundwater is 0.70902 , yielding a $\delta^{87} \mathrm{Sr}$ value of $0.25 \%$. This result lies within the range of previously reported values for groundwater samples from the NTS volcanic aquifers (Rose et al., 1997). The concentration of uranium in ER-5-4 \#2 groundwater ( $36.4 \mu \mathrm{g} / \mathrm{L})$ is unusually high, and suggests the host aquifer is also highly enriched in uranium. The ${ }^{234} \mathrm{U} /{ }^{238} \mathrm{U}$ activity ratio (1.31) is low compared to values reported in Paces et al. (2002) for other NTS groundwaters. Activity ratios near unity suggest the ${ }^{234} \mathrm{U} /{ }^{238} \mathrm{U}$ in the groundwater is close to equilibrium with the aquifer matrix.

The chemical and isotopic data for ER-5-4 \#2 groundwater are generally consistent with a long groundwater residence time. Supporting evidence includes the high concentrations of dissolved ions, depleted stable isotope values, low DIC ${ }^{14} \mathrm{C}$ value, and low ${ }^{36} \mathrm{Cl} / \mathrm{Cl}$ ratio. The ${ }^{4} \mathrm{He}$ concentration is much lower than expected in the context of these other parameters, and probably indicates that the groundwater underwent degassing as it 
ascended up the 2-km-long well bore. It is notable that ER-5-4 \#2 groundwater does not resemble any other groundwater from Frenchman Flat in terms of its chemical and isotopic characteristics. This suggests the groundwater in the deep volcanic units in Frenchman Flat may be more-or-less isolated from the regional flow system.

\section{Yucca Flat}

Four new environmental monitoring wells were drilled and completed in Yucca Flat during FY 2003 as part of the Yucca Flat Corrective Action Unit (CAU) Phase I drilling program. These include wells ER-6-1 \#2, ER-12-2, ER-7-1, and ER-2-1. The new wells provide valuable insight into the hydrogeology of the Yucca Flat basin and help to meet a variety of scientific objectives in support of the UGTA project (see IT Corporation, 2002). Analytical results and interpretations of the LLNL geochemical results for these sites are summarized below. The data are compiled in Tables 1 through 5 at the end of this chapter.

\section{Well ER-6-1 \#2}

ER-6-1 \#2 is located in the northeastern part of Area 6 in Yucca Flat. Well completion, development, and hydraulic testing data are summarized in reports by IT Corporation (2003) and Stoller-Navarro Joint Venture (2003). ER-6-1 \#2 was completed to a total depth of $975.4 \mathrm{~m}(3,200 \mathrm{ft})$ in October 2002, and casing was installed to a depth of $540.9 \mathrm{~m}$ (1774.6 ft). Below the casing is $18.1 \mathrm{~m}$ of fill, followed by open borehole to a depth of $975.4 \mathrm{~m}$. The open borehole is completed in the Paleozoic Laketown Dolomite (DSl), Ely Springs Dolomite (Oes), and Eureka Quartzite (Oe). The static water level measured in the production string prior to well development and testing was at a depth of $471.0 \mathrm{~m}(1545.1 \mathrm{ft})$ in December 2002.

Groundwater characterization samples were collected from well ER-6-1 \#2 on 16 January 2003. At the time of sampling, approximately $3.8 \times 10^{6}$ gallons of water had been pumped from the well at an average rate of $\sim 175 \mathrm{gpm}$. ER-6-1 \#2 produces a $\mathrm{Na}-\mathrm{Ca}$ bicarbonate groundwater with a moderate electrical conductivity $(408 \mu \mathrm{S} / \mathrm{cm})$ and nearneutral $\mathrm{pH}$ (7.58). The major ion chemistry of the water is similar to that of nearby well ER-6-1, which is completed in the same lithologic units, but more dilute than the water from several nearby lower carbonate aquifer (LCA) wells, including ER-3-1, UE-1h, and WW-C. Elevated levels of $\mathrm{Na}^{+}$and $\mathrm{SO}_{4}{ }^{2-}$ in the ER-6-1 \#2 samples may indicate a component of vertical leakage from the overlying Cenozoic volcanic rocks, as proposed by Winograd and Thordarson (1975). ER-6-1 \#2 groundwater has $\delta \mathrm{D}$ and $\delta^{18} \mathrm{O}$ values that are generally consistent with regional underflow within the LCA (Winograd and Friedman, 1972), though the $\delta \mathrm{D}$ value $(-105 \%)$ is higher than in several nearby LCA wells, including ER-6-1 $(\delta \mathrm{D}=-109 \%)$.

ER-6-1 \#2 groundwater was analyzed for tritium by the helium accumulation method (Surano et al., 1992). The sample contained a small amount of tritium $(31 \mathrm{pCi} / \mathrm{L})$, but the reported value is considered to be an upper limit due to possible contamination after sampling. Tritium concentrations up to $\sim 1000 \mathrm{pCi} / \mathrm{L}$ were reported during drilling (IT Corporation, 2003), but these data have a high degree of uncertainty because they are 
near the detection limit for field-deployed liquid scintillation counters. Dissolved noble gas samples were collected in two separate copper tubes at ER-6-1 \#2, but the sample runs were aborted for both tubes due to high initial pressures. Both tubes showed before and after weights that indicated the presence of a small void space filled with air. It is not possible to perform noble gas analyses under these circumstances. LLNL field notes from the ER-6-1 \#2 sampling operation mention the presence of "noticeable entrained air" in the sample collection line.

The ${ }^{14} \mathrm{C}$ value of dissolved inorganic carbon (DIC) in ER-6-1 \#2 is 2.4 percent modern, yielding an uncorrected ${ }^{14} \mathrm{C}$ age of 30,800 years. The $\delta^{13} \mathrm{C}$ value of the DIC $(-5.9 \%)$ is consistent with partial equilibration of the groundwater with carbonate minerals in the aquifer. Note that the uncorrected ${ }^{14} \mathrm{C}$ age represents the maximum mean value. Flow path modeling using a chemical mass balance program (e.g. Plummer et al., 1994) is generally needed to develop reasonable ${ }^{14} \mathrm{C}$ age corrections. ER-6-1 \#2 groundwater has a chloride concentration of $10.0 \mathrm{mg} / \mathrm{L}$ and a ${ }^{36} \mathrm{Cl} / \mathrm{Cl}$ ratio of $6.31 \times 10^{-13}$. The concentration and ratio values more closely resemble groundwater from the volcanic aquifers than the carbonate aquifer. This may again suggest a component of mixing with groundwater from the overlying Cenozoic units.

The ${ }^{87} \mathrm{Sr} /{ }^{86} \mathrm{Sr}$ ratio in ER-6-1 \#2 groundwater is 0.71295 , yielding a $\delta^{87} \mathrm{Sr}$ value of $+5.29 \%$. This is similar to values observed in other LCA groundwaters from Yucca Flat (e.g., Rose et al., 1997) and the Ash Meadows regional flow system (Peterman et al., 1992). The uranium concentration in ER-6-1 \#2 groundwater $(3.2 \mu \mathrm{g} / \mathrm{L})$ is typical of carbonate aquifer groundwaters at the NTS (Paces et al., 2002) and the ${ }^{235} \mathrm{U} /{ }^{238} \mathrm{U}$ ratio $(0.007)$ indicates the uranium is natural in origin. The ${ }^{234} U{ }^{238} U$ activity ratio (4.19) is also consistent with previously reported values for carbonate aquifer groundwater samples.

In general, the ER-6-1 \#2 data appear to reflect regional groundwater transport through the LCA. We note, however, that some of the chemical and isotopic parameters may suggest mixing with groundwater from the overlying volcanic and/or alluvial aquifers. The ${ }^{36} \mathrm{Cl} / \mathrm{Cl}$ results provide the most compelling evidence for this process. Groundwater that has followed a long flow path through the LCA will normally exhibit low ${ }^{36} \mathrm{Cl} / \mathrm{Cl}$ ratios and high $\mathrm{Cl}$ values (Moran and Rose, 2003). In contrast, ER-6-1 \#2 groundwater has a dilute $\mathrm{Cl}$ concentration and an elevated ${ }^{36} \mathrm{Cl} / \mathrm{Cl}$ ratio, similar to groundwater from the alluvial and volcanic aquifers in Yucca and Frenchman Flats. Groundwater samples from several other wells in Yucca Flat show this same pattern. A more comprehensive analysis of the ${ }^{36} \mathrm{Cl} / \mathrm{Cl}$ results for LCA groundwater samples is presented later in this chapter, in the section that discusses well ER-7-1.

\section{Well ER-12-2}

ER-12-2 is located in Area 12, in the northwestern part of Yucca Flat. The well was drilled to a total depth of 2,097.9 m (6,883 ft) between November 2002 and January 2003 and was completed with carbon steel casing cemented to a depth of $901.7 \mathrm{~m}(2958.2 \mathrm{ft})$. The borehole deviated to the north during drilling, and the true vertical depth is $1,896.0 \mathrm{~m}$ $(6,220.6 \mathrm{ft})$. Groundwater is produced from the open borehole between $901.7 \mathrm{~m}$ and 
2,097.9 m, where the lithology consists of shale and siliciclastic rocks of the Eleana Formation (MDe). The static water level was at a depth of $58.2 \mathrm{~m}$ (191 ft) in July 2003. Well completion, development, and hydraulic testing data are summarized in reports by Shaw Environmental (2003c, 2003d).

Groundwater characterization samples were collected from well ER-12-2 on 01 April 2003. At the time of sampling, approximately $3.52 \times 10^{5}$ gallons of water had been pumped from the well, and the pumping rate was $\sim 17 \mathrm{gpm}$. ER-12-2 produces a sodium bicarbonate groundwater with a $\mathrm{pH}$ of 8.06 and an electrical conductivity of $528 \mu \mathrm{S} / \mathrm{cm}$. The stable isotope $\left(\delta \mathrm{D}\right.$ and $\left.\delta^{18} \mathrm{O}\right)$ composition of the water is depleted in heavy isotopes relative to the average value for precipitation on Rainier Mesa (Ingraham et al., 1991). In comparison, seepage from the U12n tunnel complex on Rainier Mesa reflects the recharge of predominantly winter precipitation with more negative $\delta \mathrm{D}$ and $\delta^{18} \mathrm{O}$ values (Russell et al., 1987) and is much closer in composition to ER-12-2 groundwater. Hence, we cannot rule out a possible component of modern recharge (from Rainier Mesa) based on the stable isotope evidence. It is notable that groundwater from other wells completed in the Eleana Formation (e.g. UE-17a, UE-16d) and the LCA3 thrust block (UE-2ce) all have similarly enriched stable isotope compositions. These data suggest the stable isotope values observed at ER-12-2 are characteristic of the groundwater found in northwestern Yucca Flat.

The tritium activity in ER-12-2 groundwater was analyzed by the helium accumulation method (Surano et al., 1992). The results show the presence of a small but detectable amount of tritium in the water $(4.3 \mathrm{pCi} / \mathrm{L})$. Tritium was encountered during well drilling at activities up to $\sim 3,000 \mathrm{pCi} / \mathrm{L}$, but these values are associated with a high level of analytical uncertainty. We consider the tritium concentration reported here to be an upper limit due to possible post-sampling contamination. The ${ }^{3} \mathrm{He} /{ }^{4} \mathrm{He}$ ratio in ER-12-2 groundwater $\left(\mathrm{R}=3.80 \times 10^{-8}\right)$ is more than an order of magnitude below that of the natural atmospheric ratio $\left(\mathrm{R}_{\mathrm{a}}=1.38 \times 10^{-6}\right)$. The low $\mathrm{R} / \mathrm{R}_{\mathrm{a}}$ ratio $(0.028)$ reflects a large amount of excess ${ }^{4} \mathrm{He}$ in the water from the decay of $\mathrm{U}$ and $\mathrm{Th}$ in the aquifer. The time scale for this much buildup of ${ }^{4} \mathrm{He}$ is typically on the order of 60,000 years, although this age estimate has a large uncertainty because ${ }^{4} \mathrm{He}$ accumulation rates vary depending on how much $\mathrm{U}$ and Th is present in the rock. The noble gas recharge temperature could not be modeled for ER-12-2 due to disequilibrium concentrations of the heavier noble gases. By choosing a reasonable recharge temperature of $15^{\circ} \mathrm{C}$, we calculate (using neon data) that the sample has a typical amount of dissolved excess air. The calculation of excess air is only weakly dependent on the temperature estimate. Using these parameters to predict the $\mathrm{Ar}, \mathrm{Kr}$, and $\mathrm{Xe}$ concentrations, we find that the measured Xe is strongly depleted in this sample relative to the predicted equilibrium value. This level of $\mathrm{Xe}$ depletion has not been previously observed. Possible mechanisms include preferential sorption of Xe onto organic-rich sediments, or interaction of the groundwater with hydrocarbons. Xenon is significantly more soluble in oil than in water.

The ${ }^{14} \mathrm{C}$ value of dissolved inorganic carbon (DIC) in ER-12-2 is 1.5 percent modern, yielding an uncorrected ${ }^{14} \mathrm{C}$ age of 34,800 years. The $\delta^{13} \mathrm{C}$ value of the DIC $(-4.9 \%$ ) suggests the groundwater has partially equilibrated with carbonate minerals in the 
aquifer, and the reported ${ }^{14} \mathrm{C}$ age should be taken as a maximum estimate. The low $\mathrm{Ca}^{2+}$ concentration in the water indicates that reactions with calcite $\left(\mathrm{CaCO}_{3}\right)$ are likely coupled with $\mathrm{Na}-\mathrm{Ca}$ ion exchange reactions with other minerals in the aquifer.

ER-12-2 groundwater has a chloride concentration of $7 \mathrm{mg} / \mathrm{L}$ and a ${ }^{36} \mathrm{Cl} / \mathrm{Cl}$ ratio of $6.90 \times 10^{-13}$. The measured ratio is elevated in comparison to the modern atmospheric value of $\sim 5 \times 10^{-13}$ for southern Nevada (Fabryka-Martin et al., 1993). Elevated ratios in older groundwaters are thought to reflect an increase in atmospheric ${ }^{36} \mathrm{Cl}$ production during late Pleistocene time, corresponding to periods of reduced strength in the earth's magnetic field (Tyler et al., 1996). Atmospheric ${ }^{36} \mathrm{Cl}$ production rates 20,000 years ago were estimated to be a factor of 1.6 higher than the modern value, implying an initial ratio of $\sim 8 \times 10^{-13}$ in southern Nevada at that time. Assuming these models are correct, the observed ${ }^{36} \mathrm{Cl} / \mathrm{Cl}$ ratio in the ER-12-2 sample may reflect groundwater recharge during a period of higher atmospheric ${ }^{36} \mathrm{Cl}$ production rates $(>10,000$ years ago $)$.

The ${ }^{87} \mathrm{Sr} /{ }^{86} \mathrm{Sr}$ ratio in ER-12-2 groundwater is 0.71662 , yielding a $\delta^{87} \mathrm{Sr}$ value of $+10.46 \%$. This isotope ratio is higher than the values seen in most NTS groundwaters (e.g. Peterman et al., 1992; Rose et al., 1997). However, groundwater that has interacted with Paleozoic or Precambrian clastic rocks will often show higher ${ }^{87} \mathrm{Sr} /{ }^{86} \mathrm{Sr}$ ratios due to in-growth of ${ }^{87} \mathrm{Sr}$ from the decay of ${ }^{87} \mathrm{Rb}$ in the rock. The uranium concentration in the groundwater $(0.02 \mu \mathrm{g} / \mathrm{L})$ is lower than previously reported values for Yucca Flat, although Paces et al. (2002) observed similar values for other locations in southern Nevada. The ${ }^{235} \mathrm{U} /{ }^{238} \mathrm{U}$ ratio in the groundwater (0.007) indicates the uranium is natural in origin. Enrichment in the ${ }^{234} \mathrm{U} /{ }^{238} \mathrm{U}$ activity ratio (3.26) reflects the preferential leaching of ${ }^{234} \mathrm{U}$ from uranium-bearing minerals in the aquifer matrix following $\alpha$-decay of ${ }^{238} \mathrm{U}$. The observed enrichment is typical of the activity ratios observed in groundwater throughout the region (Paces et al., 2002).

In summary, the chemical and isotopic results for ER-12-2 are consistent with a mean groundwater residence time on the order of 10,000 years or more based on interpretation of the ${ }^{36} \mathrm{Cl} / \mathrm{Cl}$ and ${ }^{14} \mathrm{C}$ data, but less than $\sim 60,000$ years based in the ${ }^{4} \mathrm{He}$ data. In contrast, the $\delta \mathrm{D}$ and $\delta^{18} \mathrm{O}$ data do not necessarily reflect a late-Pleistocene ( $>10 \mathrm{ky}$ ) isotopic signature, but instead suggest that ER-12-2 groundwater may be derived from more recent recharge on Rainier Mesa. The large open interval in the ER-12-2 borehole likely produces a mixture of waters representing a range of ages, which may account for some of the difficulty in developing a consistent data interpretation. Ultimately, the ER-12-2 data will need to be interpreted in the context of other data for Yucca Flat in order to develop conceptual models for groundwater sources and residence times.

\section{Well ER-7-1}

Well ER-7-1 is located in Area 7 of the NTS, in the eastern part of Yucca Flat. The well was completed to a depth of $762.0 \mathrm{~m}(2,500 \mathrm{ft})$ in February 2003, and produces groundwater from a slotted interval $664.9-755.7 \mathrm{~m}(2,182-2,479 \mathrm{ft})$ below the ground surface. The depth to water measured on 10 Dec 2003 was $565.0 \mathrm{~m}(1,853.6 \mathrm{ft})$. Paleozoic carbonate rocks occur below a depth of $515.1 \mathrm{~m}(1,690 \mathrm{ft})$, and groundwater production is entirely from the lower carbonate aquifer (LCA). Well completion, 
development, and hydraulic testing data for ER-7-1 are summarized in reports by Shaw Environmental (2003e) and Stoller-Navarro Joint Venture (2004a).

One of the technical objectives of well ER-7-1 was to determine whether radionuclides from nearby underground nuclear tests were present in the LCA at this location. ER-7-1 is located $198 \mathrm{~m}(649 \mathrm{ft})$ south of emplacement hole U-7w, where the Torrido test was conducted in May 1969 (Stoller-Navarro Joint Venture, 2004a). Torrido was one of only a few NTS tests conducted within or very near the LCA (working point $=514.8 \mathrm{~m} \mathrm{depth}$ ). Assuming the depth to water at $\mathrm{U}-7 \mathrm{w}$ is similar to that at ER-7-1, we can infer the Torrido working point was $\sim 50 \mathrm{~m}$ above the water table. The announced yield for the test (20-200 kt; DOE/NV, 2000) gives a calculated cavity radius in the range of 33 to 71 meters, implying the lower part of the cavity may have intersected the water table.

Composite groundwater characterization samples were collected from ER-7-1 on 17 July 2003. At the time of sampling, approximately $3.55 \times 10^{6}$ gallons of water had been pumped from the well at a rate of $\sim 156$ gpm. Well ER-7-1 produces $\mathrm{Na}-\mathrm{Ca}-\mathrm{HCO}_{3}$ groundwater that contains moderate levels of $\mathrm{Mg}$ and $\mathrm{SO}_{4}$, with $\mathrm{Na}^{+}>\mathrm{Ca}^{2+}$. The concentration of major ion constituents in ER-7-1 groundwater is more dilute than in many NTS carbonate aquifer samples (conductivity $=488 \mu \mathrm{S} / \mathrm{cm}$ ), but is similar to that of wells ER-6-1 and ER-6-1 \#2, which are also located in eastern Yucca Flat. The stable isotope composition of ER-7-1 groundwater $\left(\delta \mathrm{D}=-106 \% ; \delta^{18} \mathrm{O}=-14.1 \%\right.$ ) is also similar to that of ER-6-1 \#2, but is more enriched in deuterium than some of the other LCA groundwaters in Yucca Flat.

The tritium activity in ER-7-1 groundwater was analyzed by the helium accumulation method (Surano et al., 1992). Although the measured activity (117 pCi/L) may reflect low-level radionuclide migration from the Torrido test, this interpretation is uncertain due to the possibility of post-sampling contamination. The ${ }^{3} \mathrm{He} /{ }^{4} \mathrm{He}$ ratio in ER-7-1 groundwater $\left(\mathrm{R}=8.06 \times 10^{-7}\right)$ is below the natural atmospheric ratio $\left(\mathrm{R}_{\mathrm{a}}=1.38 \times 10^{-6}\right)$, giving a low $\mathrm{R} / \mathrm{R}_{\mathrm{a}}$ ratio of 0.58 . This ratio reflects an excess of dissolved ${ }^{4} \mathrm{He}$ relative to the expected atmospheric equilibrium value. The relative abundance of the other dissolved noble gases suggests that $>95 \%$ of the ${ }^{4} \mathrm{He}$ in ER-7-1 originated from the radioactive decay of $U$ and $T h$ in the aquifer. Assuming an average ${ }^{4} \mathrm{He}$-accumulation rate of $1.35 \times 10^{9}$ atoms $/ \mathrm{g} / \mathrm{yr}$, we calculate a mean groundwater residence time on the order of 30,000 years.

The ${ }^{14} \mathrm{C}$ value of dissolved inorganic carbon (DIC) in ER-7-1 groundwater is 5.3 percent modern, yielding an uncorrected ${ }^{14} \mathrm{C}$ age of 24,300 years. However, the DIC has a lower $\delta^{13} \mathrm{C}$ value (-5.8\%) than expected for groundwater in equilibrium with carbonate rock. We interpret these data as possible evidence for mixing of a low- ${ }^{13} \mathrm{C}$ groundwater from the overlying Tertiary volcanic units with high $-{ }^{13} \mathrm{C}$ LCA groundwater entering Yucca Flat along a regional flow path. Hypothetical mixing components that fit this conceptual model are known to exist in southeastern Yucca Flat, including the volcanic aquifer groundwater at Test Well $\mathrm{B}\left(\delta^{13} \mathrm{C}=-10.2 \%\right.$; $\left.{ }^{14} \mathrm{C}=20.3 \mathrm{pmc}\right)$ and regional LCA groundwater at ER-3-1 $\left(\delta^{13} \mathrm{C}=-2.8 \% ;{ }^{14} \mathrm{C}=0.8 \mathrm{pmc}\right)$. This vertical flux concept is not new for Yucca Flat, and was first proposed by Winograd and Thordarson (1975) to help 
explain $\mathrm{Na}$ and $\mathrm{SO}_{4}$ enrichments in the LCA groundwater. However, perhaps the best evidence for this process comes from ${ }^{36} \mathrm{Cl} / \mathrm{Cl}$ data.

The chloride concentration in well ER-7-1 $(9.5 \mathrm{mg} / \mathrm{L})$ is lower than expected for groundwater in equilibrium with the LCA, but is not unique among the LCA waters from the eastern NTS. On a plot of $\mathrm{Cl}$ versus ${ }^{36} \mathrm{Cl} / \mathrm{Cl}$ values (Figure 2), the LCA waters show a general trend of decreasing ${ }^{36} \mathrm{Cl} / \mathrm{Cl}$ with increasing $\mathrm{Cl}$ concentration, with the high $\mathrm{Cl}$, low ${ }^{36} \mathrm{Cl} / \mathrm{Cl}$ samples reflecting the greatest extent of water-rock reaction with chloriderich carbonate rocks (Moran and Rose, 2003). Of particular note is the systematic variation in ${ }^{36} \mathrm{Cl} / \mathrm{Cl}$ as a function of depth in the three production zones of well UE-10j.

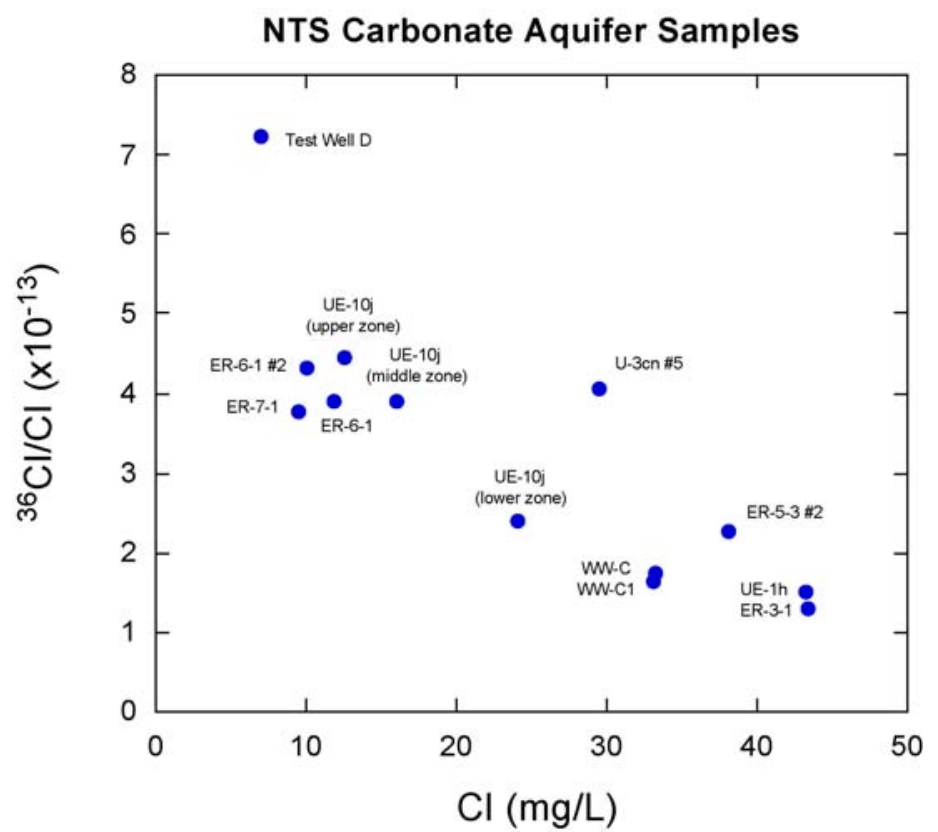

Figure 2. Plot of chloride concentrations versus ${ }^{36} \mathrm{Cl} / \mathrm{Cl}$ ratios for groundwater from the lower carbonate aquifer (LCA) at the Nevada Test Site. Compared to the high-Cl, low- ${ }^{36} \mathrm{Cl}$ LCA waters such as ER-3-1, the groundwater from ER-7-1 has a low chloride concentration $(9.5 \mathrm{mg} / \mathrm{L})$ and shows only a moderate enrichment in ${ }^{36} \mathrm{Cl}$. This chemical signature may reflect the dilution of more concentrated LCA water with low- $\mathrm{Cl}$, high $-{ }^{36} \mathrm{Cl}$ groundwater from the overlying Tertiary volcanic units.

Well UE-10j, which is located in northern Yucca Flat, was constructed such that pumped groundwater samples could be obtained from three discrete depth intervals in the LCA. The data in Figure 2 shows decreasing chloride concentrations and increasing ${ }^{36} \mathrm{Cl} / \mathrm{Cl}$ ratios at shallower depths in well UE-10j, implying mixing with more dilute water from the overlying lithologic units. Groundwater in the volcanic and alluvial aquifers tends to have high ${ }^{36} \mathrm{Cl} / \mathrm{Cl}$ ratios (up to $8.5 \times 10^{-13}$ ) and low chloride concentrations (typically 5 to $20 \mathrm{mg} / \mathrm{L}$ ) that could account for this dilution effect (see Moran and Rose, 2003). Note 
that ER-7-1 clusters with samples from ER-6-1, ER-6-1 \#2, and UE-10j, all of which show low $\mathrm{Cl}$ values and moderate ${ }^{36} \mathrm{Cl} / \mathrm{Cl}$ ratios (near $4 \times 10^{-13}$ ). These data appear to be consistent with the conceptual model for vertical transport from the overlying Tertiary units into the LCA, although the timescale of this process remains uncertain.

The ${ }^{129} \mathrm{I} / \mathrm{I}$ ratio in ER-7-1 groundwater was analyzed by accelerator mass spectrometry and was found to be $<1.0 \times 10^{-9}$. Given the stable iodine concentration of the water $(8.1$ $\mu \mathrm{g} / \mathrm{L})$, the ${ }^{129} \mathrm{I}$ concentration is estimated to be $<3.8 \times 10^{7}$ atoms per liter of $\mathrm{H}_{2} \mathrm{O}$. ER-7-1 is one of the first NTS environmental wells we have analyzed for ${ }^{129} \mathrm{I} / \mathrm{I}$. The analytical result shows that the water is close to the expected background level. Higher sensitivity measurements (with lower detection limits) are theoretically possible in the future, but for the purposes of the UGTA project, the present level of sensitivity is adequate for identifying even very low-level ${ }^{129}$ I contamination from underground testing.

The ${ }^{87} \mathrm{Sr} /{ }^{86} \mathrm{Sr}$ ratio in ER-7-1 groundwater is 0.71306 , giving a $\delta^{87} \mathrm{Sr}$ value of $+5.44 \%$. Most marine carbonate rocks have unaltered ${ }^{87} \mathrm{Sr} /{ }^{86} \mathrm{Sr}$ ratios in the range of 0.7078 to 0.7093 (Faure, 1986). Hence, the high ${ }^{87} \mathrm{Sr} /{ }^{86} \mathrm{Sr}$ ratio in ER-7-1 groundwater either reflects locally altered carbonate rock, or was inherited from a different source rock. Other potential sources of strontium isotope enrichment include the overlying Tertiary volcanic rocks and/or Paleozoic or Precambrian clastic rocks. The latter may show highly elevated ${ }^{87} \mathrm{Sr} /{ }^{86} \mathrm{Sr}$ ratios due to the in-growth of ${ }^{87} \mathrm{Sr}$ from ${ }^{87} \mathrm{Rb}$ decay over long periods of time. Peterman et al. (1992) showed that $\delta^{87} \mathrm{Sr}$ values similar to that of ER-7-1 groundwater are common in the Ash Meadows flow system.

The uranium concentration in ER-7-1 $(1.4 \mu \mathrm{g} / \mathrm{L})$ is within the range of expected values for LCA groundwater in southern Nevada (e.g. Paces et al., 2002), and the ${ }^{235} \mathrm{U} /{ }^{238} \mathrm{U}$ ratio indicates the uranium is of natural origin. The ${ }^{234} \mathrm{U} /{ }^{238} \mathrm{U}$ activity ratio (3.41) is typical of the values reported for carbonate aquifer groundwaters in this region. The observed enrichment in dissolved ${ }^{234} \mathrm{U}$ reflects the preferential leaching of uranium from the aquifer matrix following $\alpha$-decay of ${ }^{238} \mathrm{U}$.

\section{Well ER-2-1}

ER-2-1 is located in the southeastern part of Area 2, in north-central Yucca Flat. The well was completed to a total depth of $792.5 \mathrm{~m}(2,600 \mathrm{ft})$ in March 2003, with a single interval of slotted casing between 500.4 and $632.8 \mathrm{~m}(1,642-2,076 \mathrm{ft})$ below the surface. The depth to water was measured at $526.2 \mathrm{~m}(1,726.4 \mathrm{ft})$ below the surface in October 2003. Saturated rocks consist of Tertiary ash-flow tuffs and zeolitized bedded tuffs. Well completion, development, and hydraulic testing data are summarized in reports by Shaw Environmental (2003f) and Stoller-Navarro Joint Venture (2004b).

ER-2-1 was constructed near a cluster of underground nuclear tests with the objective of acquiring data on the radiological and hydrogeologic environment in a saturated volcanic aquifer setting (IT Corporation, 2002). However, the level of tritium activity encountered during drilling operations was surprisingly low, with a maximum value of only $\sim 8,700$ $\mathrm{pCi} / \mathrm{L}$. Moreover, the peak tritium activity was in the unsaturated zone, with only sporadic measurements up to $1,200 \mathrm{pCi} / \mathrm{L}$ below the water table. During well 
development and testing, large drawdown occurred at the lowest possible production rates (Stoller-Navarro Joint Venture, 2004b), implying very low hydraulic conductivities for the volcanic units within the production interval.

Composite groundwater characterization samples were collected from ER-2-1 on 03 September 2003. At the time of sampling, the pump rate was $\sim 3.5 \mathrm{gpm}$, and the cumulative purge volume was $\sim 2.15 \times 10^{4}$ gallons of water. ER-2-1 produces a dilute $\mathrm{Na}-\mathrm{HCO}_{3}$ groundwater with low conductivity $(368 \mu \mathrm{S} / \mathrm{cm})$ and slightly alkaline $\mathrm{pH}(9.3)$. The groundwater stable isotope values $\left(\delta \mathrm{D}=-109.5 \% ; \delta^{18} \mathrm{O}=-14.2 \%\right.$ ) are among the lowest observed in the volcanic or alluvial aquifers in Yucca Flat. This suggests the well is producing 'paleowater' that was recharged during a cooler climate episode, more than 10,000 years ago.

ER-2-1 groundwater has a tritium activity of $228 \mathrm{pCi} / \mathrm{L}$, as determined by the helium accumulation method (Surano et al., 1992). Considering that tritium was encountered during drilling, and that ER-2-1 is situated in close proximity to several underground nuclear tests, it is probable that the observed tritium activity reflects low-level contaminant transport. This interpretation is supported by the helium isotope data. The measured ${ }^{3} \mathrm{He} /{ }^{4} \mathrm{He}$ ratio is 14.2 times the atmospheric ratio due to in-growth of ${ }^{3} \mathrm{He}$ from tritium decay. The mean ${ }^{3} \mathrm{H}^{-3} \mathrm{He}$ age calculated for this sample is 38.3 years, corresponding to the mid-1960s. Two nearby tests were conducted in this time frame: Agile (U-2v) and Commodore (U-2am), both of which were detonated in 1967. Both tests had working points below the water table, and both are located to the northwest of well ER-2-1.

Dissolved inorganic carbon (DIC) in ER-2-1 groundwater has a ${ }^{14} \mathrm{C}$ value of $18.2 \mathrm{pmc}$, yielding an uncorrected ${ }^{14} \mathrm{C}$ age of 14,100 years. The $\delta{ }^{13} \mathrm{C}$ value is unusually depleted in ${ }^{13} \mathrm{C}(-12.1 \%)$ implying almost no equilibration with carbonate minerals in the aquifer. Under these circumstances, the uncorrected radiocarbon age may be close to the actual mean residence time of the groundwater. Although a small amount of test-derived tritium and helium is present in the water, ${ }^{14} \mathrm{C}$ tends is more reactive during groundwater transport, and the observed radiocarbon signature is probably natural in origin.

ER-2-1 groundwater has a dilute chloride concentration $(4.4 \mathrm{mg} / \mathrm{L})$ and a ${ }^{36} \mathrm{Cl} / \mathrm{Cl}$ ratio $\left(7.19 \times 10^{-13}\right)$ well above the modern atmospheric ratio for southern Nevada $\left(\sim 5 \times 10^{-13}\right.$, Fabryka-Martin et al., 1993). Two different interpretations can be developed for these data. One possibility is that the ${ }^{36} \mathrm{Cl}$ enrichment is related to contaminant transport from nearby underground tests. Since chloride is a non-reactive tracer in groundwater systems, ${ }^{36} \mathrm{Cl}$ should move at approximately the same rate as tritium in an advective flow system. Alternatively, the ${ }^{36} \mathrm{Cl}$ enrichment may reflect groundwater recharge during the last pluvial period (late Pleistocene), during which time the atmospheric production of ${ }^{36} \mathrm{Cl}$ was greater due to the reduced strength in the earth's magnetic field (Mazaud et al., 1991). Although the ER-2-1 stable isotope and radiocarbon data tend to support the latter hypothesis, we cannot say that one idea is more credible than the other. The ${ }^{129} \mathrm{I} /{ }^{127} \mathrm{I}$ ratio in ER-2-1 groundwater is $<5 \times 10^{-10}$, which is close to natural environmental levels. The 
concentration of ${ }^{129} \mathrm{I}$ is estimated to be $<1.3 \times 10^{7}$ atoms/L based on the measured stable iodine concentration of $5.3 \mu \mathrm{g} / \mathrm{L}$.

The groundwater from ER-2-1 has a ${ }^{87} \mathrm{Sr} /{ }^{86} \mathrm{Sr}$ ratio of 0.71210 and a $\delta^{87} \mathrm{Sr}$ value of $+4.09 \%$. These values are somewhat higher than normally observed for groundwater from the volcanic section, though Peterman et al. (1993) showed that some of the volcanic tuffs at Yucca Mountain have ${ }^{87} \mathrm{Sr} /{ }^{86} \mathrm{Sr}$ ratios in this range. The concentration of dissolved uranium $(3.4 \mu \mathrm{g} / \mathrm{L})$ is within the normal range of values for groundwater from the NTS volcanic units, and the ${ }^{235} \mathrm{U} /{ }^{238} \mathrm{U}$ ratio shows the uranium is natural in origin. The ${ }^{234} \mathrm{U} /{ }^{238} \mathrm{U}$-activity ratio (2.71) falls within the range of previously reported ratios for the volcanic aquifers in the region (Paces et al., 2002).

In conclusion, it is noteworthy that well ER-2-1 is located adjacent to several underground nuclear tests, but the groundwater produced by the well contains only low levels of tritium $(228 \mathrm{pCi} / \mathrm{L})$. The large and rapid drawdown that occurs when the well is pumped reveals that the water-bearing volcanic units are relatively impermeable. This suggests the risk of radionuclide transport in this part of Yucca Flat is probably minimal, and that structurally controlled "fast paths" are probably the only feasible mechanism for transport over significant distances in this hydrogeologic setting.

\section{Western Pahute Mesa - Oasis Valley Wells}

Eight deep exploratory/monitoring wells were drilled and completed in a broad geographic area of the Western Pahute Mesa-Oasis Valley (WPM-OV) groundwater flow system during 1999 and early 2000. Seven of the wells are located west of the Nevada Test Site boundary on the Nellis Air Force Range, including wells ER-EC-1, ER-EC-2, ER-EC-4, ER-EC-5, ER-EC-6, ER-EC-7, and ER-EC-8 (see Figure 1). One additional well (ER-18-2) is situated on the eastern side of Timber Mountain, in Area 18 of the NTS. These wells yielded a broad range of information regarding the hydrogeology of the regional flow system between the underground testing area on Pahute Mesa and the groundwater discharge area in Oasis Valley.

All eight of the WPM-OV wells were sampled for geochemical characterization during FY 2000. LLNL prepared a series of brief reports describing the analytical results for each well (LLNL, 2000a, b; 2001a, b, c, d, e, f). During FY 2002, the geochemical data from the new wells was used to develop a revised flow path assessment for the WPM-OV flow system (Rose et al., 2002), building upon an earlier study conducted prior to construction of the new wells (Thomas et al., 2002). Data from the new wells showed that two chemically and isotopically distinct groundwater masses were present beneath Pahute Mesa, separated by a known water-level discontinuity that is generally coincident with the Purse and West Purse Faults. Groundwater down gradient from this discontinuity has intermediate compositions that suggest mixing of the two water masses (Rose et al., 2002).

A second set of groundwater characterization samples was collected from the WPM-OV wells during FY 2003. These samples provided the means to verify the FY 2000 results and determine whether the composition of the water had evolved over time. Both data 
sets are compiled in Tables 1 through 5 at the end of this chapter. In general, there was not a significant change in groundwater composition at any of the wells. Hence, the basic interpretations that were already developed for each site have not changed. For this reason, we will not discuss each well individually in this chapter, but will instead highlight the main conclusions drawn from the collective data set.

All of the WPM-OV wells produce groundwater with $\mathrm{pH}$ values close to 8 , and electrical conductivities ranging from $263 \mu \mathrm{S} / \mathrm{cm}$ (ER-EC-7) to $1277 \mu \mathrm{S} / \mathrm{cm}$ (ER-18-2). In every case, $\mathrm{Na}^{+}$and $\mathrm{HCO}_{3}^{-}$are the dominant dissolved ions, whereas $\mathrm{Cl}^{-}$and $\mathrm{SO}_{4}{ }^{2-}$ range from dilute to relatively concentrated values ( 4 to $97 \mathrm{mg} / \mathrm{L} \mathrm{Cl}^{-} ; 14$ to $119 \mathrm{mg} / \mathrm{L} \mathrm{SO}_{4}{ }^{2-}$ ). The highest chloride and sulfate values are observed at wells ER-EC-1 and ER-EC-4, which lie to the west of the Purse Fault water-level discontinuity. Groundwater to the east of this discontinuity exhibits much lower chloride and sulfate values (e.g. ER-EC-5). This difference in solute chemistry was essential to recognizing the presence of two distinct groundwater types in the WPM-OV flow system (Rose et al., 2002).

With one exception, the WPM-OV groundwaters exhibit a fairly narrow range in stable isotope values, with $\delta \mathrm{D}$ between -111 and $-117 \%$ and $\delta^{18} \mathrm{O}$ between -14.6 and $-15.0 \%$. In contrast, water from ER-EC-7 has much higher $\delta \mathrm{D}(-98 \%)$ and $\delta^{18} \mathrm{O}(-13.2 \%)$ values, and the lowest dissolved ion concentrations of any of the new wells. These data together with other lines of geochemical evidence $\left({ }^{14} \mathrm{C},{ }^{36} \mathrm{Cl}\right)$ suggest that ER-EC-7 groundwater is largely derived from local recharge. The groundwater from all other WPM-OV wells originates from more distal recharge centers, outside of the Pahute Mesa region.

The tritium activities measured in the 2003 WPM-OV well samples were generally higher than the uniform "non-detect" $(<1.5 \mathrm{pCi} / \mathrm{L})$ values determined for samples collected in 2000 (see Table 5). As with several of the Yucca Flat wells, the low levels of tritium probably originated from post-sampling contamination. This was verified by reanalyzing splits of tritium samples taken concurrently from three of the WPM-OV wells by the Shaw Environmental Group. The Shaw samples were found to contain tritium activities near or below the detection limit of $1.5 \mathrm{pCi} / \mathrm{L}$. These results are consistent with the post-sampling contamination hypothesis, and suggest that low-level tritium is not present in the WPM-OV groundwaters.

The ratio of ${ }^{3} \mathrm{He} /{ }^{4} \mathrm{He}$ in the WPM-OV samples relative to ${ }^{3} \mathrm{He} /{ }^{4} \mathrm{He}$ in air (referred to as $\mathrm{R} / \mathrm{R}_{\mathrm{a}}$ ) varies from 0.60 in ER-EC-1 to 2.01 in ER-18-2. Samples with $\mathrm{R} / \mathrm{R}_{\mathrm{a}}<1$ tend to contain excess concentrations of "crustal" ${ }^{4} \mathrm{He}$ from the alpha decay of uranium and thorium in the aquifer (e.g. ER-EC-1 and ER-EC-6). Conversely, samples that have R/R values $>1$ (but no tritium) generally contain excess "mantle" helium that is introduced into groundwater along deep faults (e.g. ER-18-2). Some of the WPM-OV groundwaters contain ${ }^{3} \mathrm{He}$ and ${ }^{4} \mathrm{He}$ concentrations much greater than the equilibrium solubility of dissolved air, but have ${ }^{3} \mathrm{He} /{ }^{4} \mathrm{He}$ ratios that are close to the ratio in air. A good example is well ER-EC-4 $\left(\mathrm{R} / \mathrm{R}_{\mathrm{a}}=1.02\right)$ which contains a large ${ }^{3} \mathrm{He}$ excess that may have originated from the nearby Thirsty Canyon lineament (Grauch et al., 1997) together with a ${ }^{4} \mathrm{He}$ excess from the $\alpha$-decay of $U$ and $T h$ in the aquifer host rocks. 
The excess ${ }^{4} \mathrm{He}$ in the water is useful for obtaining semi-quantitative estimates of groundwater residence times. Assuming the ${ }^{4} \mathrm{He}$ originates entirely from $\alpha$-decay processes in the aquifer (no external sources) at a steady state in-growth rate of $1.35 \times 10^{9}$ atoms $/ \mathrm{g} /$ year, we estimate groundwater residence times ranging from 2,000 to 10,000 years for all but one of the WPM-OV wells. These data suggest most of the groundwater in the WPM-OV flow system is Holocene in age. The ${ }^{4} \mathrm{He}$ excess in ER-18-2 implies a much greater residence time $\left(\sim 10^{5}\right.$ years $)$ but this well is situated along the structural margin of the Timber Mountain caldera and has the highest $\mathrm{R} / \mathrm{R}_{\mathrm{a}}$ value in the WPM-OV region. Hence, the groundwater from ER-18-2 probably is not representative of the main part of the regional flow system.

Dissolved inorganic carbon (DIC) in groundwater from the WPM-OV wells has ${ }^{14} \mathrm{C}$ values that range from 46.2 pmc (ER-EC-7) to 0.4 pmc (ER-18-2), yielding uncorrected ${ }^{14} \mathrm{C}$ ages between 6,400 and 45,600 years. The remaining six wells (ER-EC-1, -2A, -4 , $-5,-6$, and -8 ) show a narrower range in ${ }^{14} \mathrm{C}$ values between 5.9 and $8.0 \mathrm{pmc}$, with uncorrected ages between 20,900 and 23,400 years. It should be emphasized that these uncorrected ages are probably much greater than the true mean residence time of the groundwater due to post-recharge chemical reactions with carbonate minerals. Groundwater $\delta^{13} \mathrm{C}$ values range from $-5.5 \%$ (ER-EC-7) to $-0.5 \%$ (ER-18-2), implying moderate to extensive equilibration with carbonate minerals that occur along fractures in the volcanic aquifers. Dissolved organic carbon (DOC) analyses performed by DRI on the WPM-OV samples suggest mean groundwater ages of 10,000 years or less (see Rose et al., 2002), which is consistent with the semi-quantitative residence time estimates from the ${ }^{4} \mathrm{He}$ data.

The WPM-OV groundwater samples have ${ }^{36} \mathrm{Cl} / \mathrm{Cl}$ ratios between $7.55 \times 10^{-13}$ (ER-EC-7) and $2.31 \times 10^{-13}$ (ER-18-2), though most samples show a more restricted range in values $\left(4.90 \times 10^{-13}\right.$ to $\left.5.61 \times 10^{-13}\right)$ similar to the present-day NTS atmospheric ratio $\left(\sim 5 \times 10^{-13}\right.$; Fabryka-Martin et al., 1993). A "modern" ${ }^{36} \mathrm{Cl}$ signature seems improbable for many of these samples since: (1) it is inconsistent with groundwater age estimates based on helium and carbon isotope data; and (2) it is difficult to develop a recharge model that accounts for the necessary chloride concentrations (up to $\sim 100 \mathrm{mg} / \mathrm{L}$ ). It is more likely the waters started with higher initial ${ }^{36} \mathrm{Cl} / \mathrm{Cl}$ ratios and were subsequently "diluted" to the present levels via dissolution of ${ }^{36} \mathrm{Cl}$-absent "dead" chloride from the rock. Atmospheric ${ }^{36} \mathrm{Cl}$ production rates were higher during the late Pleistocene time (e.g. Davis et al., 1998), though mean recharge ages much greater than $\sim 10,000$ years would be inconsistent with age constraints from other parameters. Conversely, the fraction of the total dissolved chloride originating from dead chloride in the rock cannot be too large; otherwise the ${ }^{36} \mathrm{Cl} / \mathrm{Cl}$ ratios would be much lower. Interpretation of the WPM-OV ${ }^{36} \mathrm{Cl}$ data may eventually be improved as we learn more about the composition of groundwater up gradient from Pahute Mesa.

Groundwater from the WPM-OV wells has ${ }^{87} \mathrm{Sr} /{ }^{86} \mathrm{Sr}$ ratios that range from 0.70877 to 0.71056 , with corresponding $\delta^{87} \mathrm{Sr}$ values between -0.61 and $+1.92 \%$. These data are consistent with the natural Sr isotopic abundances of the volcanic tuffs from the Nevada Test Site (e.g. Peterman et al., 1993). Dissolved uranium concentrations show a fairly 
broad range of values ( 1.9 to $9.5 \mu \mathrm{g} / \mathrm{L}$ ) that may reflect variations in the uranium content of the different volcanic units. All of the WPM-OV samples exhibit natural ${ }^{235} \mathrm{U} /{ }^{238} \mathrm{U}$ ratios, but have a broad range in ${ }^{234} \mathrm{U} /{ }^{238} \mathrm{U}$-activity ratios - including an unusually high value of 12.76 in ER-18-2 groundwater. The reader is referred to a paper by Paces et al. (2002) for a more complete discussion of the uranium isotope data for this region.

In general, the FY 2003 groundwater characterization samples from the WPM-OV wells are consistent with the FY 2000 data for the same locations. This brief synopsis is intended to highlight the key features and interpretations developed from these data. A more detailed assessment of these (and other) geochemical data from the WPM-OV region can be found in recent reports by Thomas et al. (2002), Rose et al. (2002), and Kwicklis et al. (2004).

\section{References}

Christiansen, E.H., Sheridan, M.F., and Burt, D.M. (1986) The geology and geochemistry of Cenozoic topaz rhyolites from the western United States. Geological Society of America, Special Paper 205, 82 p.

Davis, S.N., Cecil, D., Zreda, M., Sharma, P. (1998) Chlorine-36 and the initial value problem. Hydrogeology Journal, 6: 104-114.

DOE/NV (2000) United States Nuclear Tests, July 1945 through September 1992. U.S. Department of Energy, Nevada Operations Office, DOE/NV-209-Rev 15, December 2000, $162 \mathrm{p}$.

Fabryka-Martin, J., Wightman, S.J., Murphy, W.J., Wickham, M.P., Caffee, M.W., Nimz, G.J., Southon, J.R., and Sharma, P. (1993) Distribution of chlorine-36 in the unsaturated zone at Yucca Mt.: An indicator of fast transport paths. FOCUS '93: Site Characterization and Model Validation, Las Vegas, NV, 26-29 Sept 1993.

Faure, G. (1986) Principles of Isotope Geology, $2^{\text {nd }}$ Edition. John Wiley \& Sons, New York, 589 p.

Grauch, V.J.S., Sawyer, D.A., Fridrich, C.J., and Hudson, M.R. (1997) Geophysical interpretations west of and within the northwestern part of the Nevada Test Site. U.S. Geological Survey Open-File Report 97-476, 45 p.

Ingraham, N.L., Lyles, B.F., Jacobson, R.L., and Hess, J.W. (1991) Stable isotopic study of precipitation and spring discharge in southern Nevada. Journal of Hydrology, v. 125, p. 243-258.

IT Corporation (2002) Yucca Flat Hydrogeologic Investigation Wells Drilling and Completion Criteria, Rev. 0. Las Vegas, NV, February 2002, 243 p.

IT Corporation (2003) Yucca Flat ER-6-1 \#2 Well Data Report, Preliminary, Rev. 0. Las Vegas, NV, March 2003, 101 p.

Kwicklis, E.M., Rose, T.P., and Benedict, F.C., Jr. (2004) Evaluation of groundwater flow in the Pahute Mesa - Oasis Valley flow system using groundwater chemical and isotopic data. 
Los Alamos National Laboratory Draft Report, prepared for the National Nuclear Security Administration, Nevada Site Office, Underground Test Area Project, 54 p.

LLNL (2000a) Isotopic Analyses: Environmental Monitoring Well ER-EC-1. Letter Report from LLNL-ANCD to UGTA Project Manager, DOE/ERD, 01 August 2000, 4 p.

LLNL (2000b) Isotopic Analyses: Environmental Monitoring Well ER-EC-6. Letter Report from LLNL-ANCD to UGTA Project Manager, DOE/ERD, 07 August 2000, 4 p.

LLNL (2001a) Isotopic Analyses: Environmental Monitoring Well ER-18-2. Letter Report from LLNL-ANCD to UGTA Project Manager, DOE/ERD, 09 January 2001, 4 p.

LLNL (2001b) Isotopic Analyses: Environmental Monitoring Well ER-EC-5. Letter Report from LLNL-ANCD to UGTA Project Manager, DOE/ERD, 28 February 2001, 4 p.

LLNL (2001c) Isotopic Analyses: Environmental Monitoring Well ER-EC-7. Letter Report from LLNL-ANCD to UGTA Project Manager, DOE/ERD, 08 May 2001, 4 p.

LLNL (2001d) Isotopic Analyses: Environmental Monitoring Well ER-EC-8. Letter Report from LLNL-ANCD to UGTA Project Manager, DOE/ERD, 22 May 2001, 4 p.

LLNL (2001e) Isotopic Analyses: Environmental Monitoring Well ER-EC-2A. Letter Report from LLNL-ANCD to UGTA Project Manager, DOE/ERD, 24 May 2001, 4 p.

LLNL (2001f) Isotopic Analyses: Environmental Monitoring Well ER-EC-4. Letter Report from LLNL-ANCD to UGTA Project Manager, DOE/ERD, 30 May 2001, 4 p.

LLNL (2004) Analytical Measurements: Standard Operating Procedures, Underground Test Area Project. Chemical Biology and Nuclear Science Division, Lawrence Livermore National Laboratory, 30 June 2004.

Moran, J.E., and Rose, T.P. (2003) A chlorine-36 study of regional groundwater flow and vertical transport in southern Nevada. Environmental Geology, v. 43, p. 592-605.

Paces, J.B., Ludwig, K.R., Peterman, Z.E., and Neymark, L.A. (2002) ${ }^{234} U /{ }^{238} U$ evidence for local recharge and patterns of groundwater flow in the vicinity of Yucca Mountain, Nevada, USA. Applied Geochemistry, v. 17, p. 751-779.

Peterman, Z.E., Stuckless, J.S., Mahan, S.A., Marshall, B.D., Gutentag, E.D. and Downey, J.S. (1992) Strontium isotope characterization of the Ash Meadows groundwater system, southern Nevada, USA In: Y.K. Kharaka and A.S. Maest, eds. Proceedings of the $7^{t^{t h}}$ International symposium on Water-Rock Interaction, 10-18 July 1992, Park City, Utah. A.A. Balkema, Rotterdam, p. 825-829.

Peterman, Z.E., Spengler, R.W., Singer, F.R, and Dickerson, R.P. (1993) Isotopic and trace element variability in altered and unaltered tuffs at Yucca Mountain, Nevada. In: High Level Radioactive Waste Management, Proceedings of the Fourth Annual International Conference, Volume 2, 26-30 April 1993, Las Vegas, Nevada. American Nuclear Society, La Grange, Illinois, p. 1940-1947. 
Plummer, L.N., Prestemon, E.C., and Parkhurst, D.L. (1994) An interactive code (NETPATH) for modeling net geochemical reactions along a flow path, version 2.0. U.S. Geological Survey, Water Resources Investigations Report 94-4169, 130 p.

Rose, T.P., Kenneally, J.M., Smith, D.K., Davisson, M.L., Hudson, G.B., and Rego, J.H. (1997) Chemical and isotopic data for groundwater in southern Nevada. Lawrence Livermore National Laboratory Report UCRL-ID-128000, 35 p.

Rose, T.P., Benedict, F.C., Jr., Thomas, J.M., Sicke, W.S., Hershey, R.L., Paces, J.B., Farnham, I.M., and Peterman, Z.E. (2002) Geochemical data analysis and interpretation of the Pahute Mesa-Oasis Valley groundwater flow system, Nye County, Nevada. Lawrence Livermore National Laboratory draft report, prepared for the U.S. Department of Energy, Nevada Operations Office, Environmental Restoration Division, August 2002, 607 p.

Russell, C.E., Hess, J.W., and Tyler, S.W. (1987) Hydrogeologic investigations of flow in fractured tuffs, Rainier Mesa, Nevada Test Site. In: Evans, D.D. and Nicholson, T.J. (eds.), Flow and Transport Through Unsaturated Fractured Rock. American Geophysical Union, Geophysical Monograph 42, Washington D.C., p. 43-50.

Shaw Environmental (2003a) Frenchman Flat ER-5-4 \#2 Well Data Report, Preliminary, Rev. 0, Las Vegas, NV, March 2003, 129 p.

Shaw Environmental (2003b) Frenchman Flat ER-5-4 \#2 Data Report for Development and Hydraulic Testing, Preliminary, Rev. 0, Las Vegas, NV, June 2003, 118 p.

Shaw Environmental (2003c) Yucca Flat ER-12-2 Well Data Report, Preliminary, Rev. 0. Las Vegas, NV, July 2003, 162 p.

Shaw Environmental (2003d) Yucca Flat Well ER-12-2 Data Report for Development and Hydraulic Testing, Preliminary, Rev. 0. Las Vegas, NV, August 2003, 116 p.

Shaw Environmental (2003e) Yucca Flat ER-7-1 Well Data Report, Preliminary, Rev. 0. Las Vegas, NV, May 2003, 109 p.

Shaw Environmental (2003f) Yucca Flat ER-2-1 Well Data Report, Preliminary, Rev. 0. Las Vegas, NV, August 2003, 122 p.

Stoller-Navarro Joint Venture (2003) Yucca Flat Well ER-6-1 \#2 Data Report for Development and Hydraulic Testing, Preliminary, Rev. 0. Las Vegas, NV, October 2003, 144 p.

Stoller-Navarro Joint Venture (2004a) Yucca Flat Well ER-7-1 Data Report for Development and Hydraulic Testing, Preliminary, Rev. 0. Las Vegas, NV, March 2004, 147 p.

Stoller-Navarro Joint Venture (2004b) Yucca Flat Well ER-2-1 Data Report for Development and Hydraulic Testing, Preliminary, Rev. 0. Las Vegas, NV, January 2004, 105 p.

Surano, K.A., Hudson, G.B., Failor, R.A., Sims, J.M., Holland, R.C., MacLean, S.C., and Garrison, J.C. (1992) Helium-3 mass spectrometry for low-level tritium analysis of environmental samples. Jour. Radioanal. Nuclear Chem. Articles, 161: 443-453. 
Thomas, J.M., Benedict, F.C, Jr., Rose, T.P., Hershey, R.L., Paces, J.B., Peterman, Z.E., Farnham, I.M., Johannesson, K.H., Singh, A.K., Stetzenbach, K.J., Hudson, G.B., Kenneally, J.M., Eaton, G.F., and Smith, D.K. (2002) Geochemical and isotopic interpretations of groundwater flow in the Oasis Valley Flow System, southern Nevada. Desert Research Institute Publication No. 45190, August 2002, 202 p.

Tyler, S.W., Chapman, J.B., Conrad, S.H., Hammermeister, D.P., Blout, D.O., Miller, J.J., Sully, M.J., and Ginanni, J.M. (1996) Soil-water flux in the southern Great Basin, United States: Temporal and spatial variations over the last 120,000 years. Water Resources Research, 32: 1481-1499.

Winograd, I.J., and Friedman, I. (1972) Deuterium as a tracer of regional groundwater flow, southern Great Basin, Nevada and California. Geological Society of America Bulletin, 83: 3691-3708.

Winograd, I.J., and Thordarson, W. (1975) Hydrogeologic and hydrochemical framework, southcentral Great Basin, Nevada-California, with special reference to the Nevada Test Site. U.S. Geological Survey Professional Paper 712-C, 126 p. 
Table 1. Environmental well construction data and sampling information.

\begin{tabular}{|c|c|c|c|c|c|c|c|c|c|}
\hline Well name & Sample date & $\begin{array}{l}\text { Latitude } \\
\text { (d m s) }\end{array}$ & $\begin{array}{l}\text { Longitude } \\
\qquad(\mathrm{d} \mathrm{m} \mathrm{s})\end{array}$ & $\begin{array}{c}\text { Surface } \\
\text { Elevation } \\
\text { (ft) }\end{array}$ & $\begin{array}{c}\text { Well } \\
\text { Depth } \\
\text { (ft bgs) }\end{array}$ & $\begin{array}{c}\text { Open Interval } \\
\text { (ft bgs) }\end{array}$ & $\begin{array}{c}\text { Volume } \\
\text { Pumped } \\
\text { (gal) }\end{array}$ & $\begin{array}{l}\text { Water } \\
\text { Depth } \\
\text { (ft bgs) }\end{array}$ & $\begin{array}{l}\text { Sample } \\
\text { Method }\end{array}$ \\
\hline \multicolumn{10}{|c|}{ Frenchman Flat } \\
\hline ER-5-4 \#2 & 21-Nov-02 & 364927 & 1155748 & 3127 & 7000 & $6486-6658$ & $3.97 E+06$ & 697 & pump \\
\hline \multicolumn{10}{|l|}{ Yucca Flat } \\
\hline ER-2-1 & 03-Sep-03 & 370731 & 1160342 & 4222 & 2600 & $1642-2076$ & $2.15 \mathrm{E}+04$ & 1723 & pump \\
\hline ER-6-1 \#2 & 16-Jan-03 & 365901 & 1155935 & 3934 & 3200 & $1775-3200$ & $3.80 E+06$ & 1545 & pump \\
\hline ER-7-1 & 17-Jul-03 & 370424 & 1155943 & 4247 & 2500 & $2182-2479$ & $3.54 \mathrm{E}+07$ & 1854 & pump \\
\hline ER-12-2 & 01-Apr-03 & 371019 & 1160721 & 4705 & 6883 & $2958-6883$ & $3.52 E+05$ & 191 & pump \\
\hline \multicolumn{10}{|c|}{ Pahute Mesa - Oasis Valley } \\
\hline $\begin{array}{l}\text { ER-EC-1 } \\
\text { ER-EC-1 }\end{array}$ & $\begin{array}{l}\text { 3-Jun-03 } \\
\text { 1-Feb-00 }\end{array}$ & $\begin{array}{l}371223 \\
371223\end{array}$ & $\begin{array}{l}1163144 \\
1163144\end{array}$ & $\begin{array}{l}6026 \\
6026\end{array}$ & $\begin{array}{l}5000 \\
5000\end{array}$ & $\begin{array}{l}2298-2821 ; 3348-3760 ; 4449-4750 \\
2298-2821 ; 3348-3760 ; 4449-4750\end{array}$ & $2.02 \mathrm{E}+05$ & $\begin{array}{l}1859 \\
1859\end{array}$ & $\begin{array}{l}\text { pump } \\
\text { pump }\end{array}$ \\
\hline $\begin{array}{l}\text { ER-EC-2A } \\
\text { ER-EC-2A }\end{array}$ & $\begin{array}{l}\text { 8-Jul-03 } \\
27-J u l-00\end{array}$ & $\begin{array}{l}370852 \\
370852\end{array}$ & $\begin{array}{l}1163405 \\
1163405\end{array}$ & $\begin{array}{l}4904 \\
4904\end{array}$ & $\begin{array}{l}4974 \\
4974\end{array}$ & $\begin{array}{l}1707-2179 ; 3077-3549 ; 4487-4916 \\
1707-2179 ; 3077-3549 ; 4487-4916\end{array}$ & $2.66 \mathrm{E}+04$ & $\begin{array}{l}748 \\
748\end{array}$ & $\begin{array}{l}\text { pump } \\
\text { pump }\end{array}$ \\
\hline $\begin{array}{l}\text { ER-EC-4 } \\
\text { ER-EC-4 }\end{array}$ & $\begin{array}{l}24-J u n-03 \\
17-\text { Aug-00 }\end{array}$ & $\begin{array}{l}370939 \\
370939\end{array}$ & $\begin{array}{l}1163752 \\
1163752\end{array}$ & $\begin{array}{l}4760 \\
4760\end{array}$ & $\begin{array}{l}3487 \\
3487\end{array}$ & $\begin{array}{l}989-1224 ; 1910-2253 ; 3103-3404 \\
989-1224 ; 1910-2253 ; 3103-3404\end{array}$ & $1.23 \mathrm{E}+05$ & $\begin{array}{l}749 \\
749\end{array}$ & $\begin{array}{l}\text { pump } \\
\text { pump }\end{array}$ \\
\hline $\begin{array}{l}\text { ER-EC-5 } \\
\text { ER-EC-5 }\end{array}$ & $\begin{array}{l}\text { 15-Jul-03 } \\
\text { 25-May-00 }\end{array}$ & $\begin{array}{l}370505 \\
370505\end{array}$ & $\begin{array}{l}1163349 \\
1163349\end{array}$ & $\begin{array}{l}5077 \\
5077\end{array}$ & $\begin{array}{l}2500 \\
2500\end{array}$ & $\begin{array}{l}\text { 1197-1399; 1892-2094; 2246-2417 } \\
\text { 1197-1399; 1892-2094; 2246-2417 }\end{array}$ & $2.21 \mathrm{E}+05$ & $\begin{array}{l}1017 \\
1017\end{array}$ & $\begin{array}{l}\text { pump } \\
\text { pump }\end{array}$ \\
\hline $\begin{array}{l}\text { ER-EC-6 } \\
\text { ER-EC-6 }\end{array}$ & $\begin{array}{l}10-J u n-03 \\
10-\text { Feb-00 }\end{array}$ & $\begin{array}{l}371126 \\
371126\end{array}$ & $\begin{array}{l}1162948 \\
1162948\end{array}$ & $\begin{array}{l}5605 \\
5605\end{array}$ & $\begin{array}{l}5000 \\
5000\end{array}$ & $\begin{array}{l}1628-1871 ; 2195-2507 ; 3438-3811 ; 4421-4904 \\
1628-1871 ; 2195-2507 ; 3438-3811 ; 4421-4904\end{array}$ & $2.15 E+05$ & $\begin{array}{l}1426 \\
1426\end{array}$ & $\begin{array}{l}\text { pump } \\
\text { pump }\end{array}$ \\
\hline $\begin{array}{l}\text { ER-EC-7 } \\
\text { ER-EC-7 }\end{array}$ & $\begin{array}{l}\text { 21-Jul-03 } \\
\text { 5-Jun-00 }\end{array}$ & $\begin{array}{l}365910 \\
365910\end{array}$ & $\begin{array}{l}1162841 \\
1162841\end{array}$ & $\begin{array}{l}4800 \\
4800\end{array}$ & $\begin{array}{l}1386 \\
1386\end{array}$ & $\begin{array}{l}920-979 ; 1215-1304 \\
920-979 ; 1215-1304\end{array}$ & $\begin{array}{c}2.90 \mathrm{E}+05 \\
---\end{array}$ & $\begin{array}{l}719 \\
719\end{array}$ & $\begin{array}{l}\text { pump } \\
\text { pump }\end{array}$ \\
\hline $\begin{array}{l}\text { ER-EC-8 } \\
\text { ER-EC-8 }\end{array}$ & $\begin{array}{c}\text { 1-Jul-03 } \\
12-J u l-00\end{array}$ & $\begin{array}{l}370617 \\
370617\end{array}$ & $\begin{array}{l}1163753 \\
1163753\end{array}$ & $\begin{array}{l}4245 \\
4245\end{array}$ & $\begin{array}{l}2000 \\
2000\end{array}$ & $\begin{array}{l}683-984 ; 1447-1507 ; 1677-1908 \\
683-984 ; 1447-1507 ; 1677-1908\end{array}$ & $\begin{array}{c}2.34 \mathrm{E}+05 \\
---\end{array}$ & $\begin{array}{l}323 \\
323\end{array}$ & $\begin{array}{l}\text { pump } \\
\text { pump }\end{array}$ \\
\hline $\begin{array}{l}\text { ER-18-2 } \\
\text { ER-18-2 }\end{array}$ & $\begin{array}{l}\text { 17-Jun-03 } \\
\text { 21-Mar-00 }\end{array}$ & $\begin{array}{l}370621 \\
370621\end{array}$ & $\begin{array}{l}1162222 \\
1162222\end{array}$ & $\begin{array}{l}5436 \\
5436\end{array}$ & $\begin{array}{l}2500 \\
2500\end{array}$ & $\begin{array}{l}\text { 1930-1960; 2000-2030; } 2071-2101 \\
1930-1960 ; 2000-2030 ; 2071-2101\end{array}$ & $\begin{array}{c}9.76 \mathrm{E}+04 \\
---\end{array}$ & $\begin{array}{l}1213 \\
1213\end{array}$ & $\begin{array}{l}\text { pump } \\
\text { pump }\end{array}$ \\
\hline
\end{tabular}

A dashed line indicates that no measurement was recorded for the listed parameter 
Table 2. Water chemistry and anion concentrations.

\begin{tabular}{|c|c|c|c|c|c|c|c|c|c|c|}
\hline Well name & Sample date & $\mathrm{pH}$ & $\begin{array}{c}\mathrm{T} \\
\left({ }^{\circ} \mathrm{C}\right)\end{array}$ & $\begin{array}{l}\text { Cond. } \\
(\mu \mathrm{S} / \mathrm{cm})\end{array}$ & $\begin{array}{c}\text { TDIC as } \\
\mathrm{HCO}_{3}^{-} \\
\text {(mg/L) }\end{array}$ & $\begin{array}{c}\mathrm{F} \\
(\mathrm{mg} / \mathrm{L})\end{array}$ & $\begin{array}{c}\mathrm{Cl} \\
(\mathrm{mg} / \mathrm{L})\end{array}$ & $\begin{array}{c}\mathrm{Br} \\
(\mathrm{mg} / \mathrm{L})\end{array}$ & $\begin{array}{c}\mathrm{NO}_{3} \\
(\mathrm{mg} / \mathrm{L})\end{array}$ & $\begin{array}{c}\mathrm{SO}_{4} \\
(\mathrm{mg} / \mathrm{L})\end{array}$ \\
\hline \multicolumn{11}{|c|}{ Frenchman Flat } \\
\hline $\begin{array}{l}\text { ER-5-4 \#2 } \\
\text { Yucca Flat }\end{array}$ & 21-Nov-02 & 8.7 & 38.1 & 1249 & 394 & 63.9 & 51.7 & $<0.5$ & $<0.1$ & 119.4 \\
\hline ER-2-1 & 03-Sep-03 & 9.3 & 21.3 & 368 & 189 & 1.8 & 4.4 & $<0.03$ & 2.4 & 15.9 \\
\hline ER-6-1 \#2 & 16-Jan-03 & 7.6 & 39.9 & 408 & 256 & 0.8 & 10.0 & 0.8 & 1.1 & 34.0 \\
\hline ER-7-1 & 17-Jul-03 & 7.6 & 49.4 & 488 & 243.5 & 0.8 & 9.5 & 0.05 & 0.07 & 34.4 \\
\hline ER-12-2 & 01-Apr-03 & 8.1 & 35.2 & 528 & 302.9 & 2.2 & 7.0 & 0.7 & $<0.2$ & 27.4 \\
\hline \multicolumn{11}{|c|}{ Pahute Mesa - Oasis Valley } \\
\hline $\begin{array}{l}\text { ER-EC-1 } \\
\text { ER-EC-1 }\end{array}$ & $\begin{array}{l}\text { 3-Jun-03 } \\
\text { 1-Feb-00 }\end{array}$ & $\begin{array}{l}8.1 \\
7.9\end{array}$ & $\begin{array}{l}34.8 \\
37.0\end{array}$ & $\begin{array}{l}782 \\
818\end{array}$ & $\begin{array}{l}148.9 \\
148.5\end{array}$ & $\begin{array}{l}2.3 \\
2.4\end{array}$ & $\begin{array}{l}97.0 \\
97.0\end{array}$ & $\begin{array}{c}1.4 \\
1.10\end{array}$ & $\begin{array}{l}2.1 \\
2.5\end{array}$ & $\begin{array}{l}119 \\
145\end{array}$ \\
\hline $\begin{array}{l}\text { ER-EC-2A } \\
\text { ER-EC-2A }\end{array}$ & $\begin{array}{c}\text { 8-Jul-03 } \\
\text { 27-Jul-00 }\end{array}$ & $\begin{array}{l}8.1 \\
7.8\end{array}$ & $\begin{array}{l}35.2 \\
40.4\end{array}$ & $\begin{array}{l}616 \\
706\end{array}$ & $\begin{array}{l}164.7 \\
170.5\end{array}$ & $\begin{array}{l}3.9 \\
5.9\end{array}$ & $\begin{array}{l}55.5 \\
63.0\end{array}$ & $\begin{array}{c}1.1 \\
0.55\end{array}$ & $\begin{array}{l}1.9 \\
1.2\end{array}$ & $\begin{array}{c}84.5 \\
99\end{array}$ \\
\hline $\begin{array}{l}\text { ER-EC-4 } \\
\text { ER-EC-4 }\end{array}$ & $\begin{array}{l}24-J u n-03 \\
17-A u g-00\end{array}$ & $\begin{array}{l}7.8 \\
7.9\end{array}$ & $\begin{array}{l}35.9 \\
38.5\end{array}$ & $\begin{array}{l}750 \\
793\end{array}$ & $\begin{array}{l}150.4 \\
158.1\end{array}$ & $\begin{array}{l}3.0 \\
3.6\end{array}$ & $\begin{array}{l}80.6 \\
95.7\end{array}$ & $\begin{array}{c}1.2 \\
1.26\end{array}$ & $\begin{array}{l}2.4 \\
3.2\end{array}$ & $\begin{array}{l}109 \\
130\end{array}$ \\
\hline $\begin{array}{l}\text { ER-EC-5 } \\
\text { ER-EC-5 }\end{array}$ & $\begin{array}{c}\text { 15-Jul-03 } \\
25-M a y-00\end{array}$ & $\begin{array}{l}7.9 \\
7.9\end{array}$ & $\begin{array}{l}29.7 \\
29.9\end{array}$ & $\begin{array}{l}412 \\
424\end{array}$ & $\begin{array}{l}180.4 \\
175.7\end{array}$ & $\begin{array}{l}4.3 \\
4.6\end{array}$ & $\begin{array}{l}15.9 \\
16.1\end{array}$ & $\begin{array}{l}0.7 \\
\text { n.d. }\end{array}$ & $\begin{array}{l}1.7 \\
1.2\end{array}$ & $\begin{array}{c}36.3 \\
35\end{array}$ \\
\hline $\begin{array}{l}\text { ER-EC-6 } \\
\text { ER-EC-6 }\end{array}$ & $\begin{array}{l}10-J u n-03 \\
10-F e b-00\end{array}$ & $\begin{array}{l}8.1 \\
8.1\end{array}$ & $\begin{array}{l}33.9 \\
37.9\end{array}$ & $\begin{array}{l}516 \\
613\end{array}$ & $\begin{array}{l}147.0 \\
153.2\end{array}$ & $\begin{array}{l}2.7 \\
3.1\end{array}$ & $\begin{array}{l}51.7 \\
44.0\end{array}$ & $\begin{array}{c}0.9 \\
0.84\end{array}$ & $\begin{array}{l}2.0 \\
2.0\end{array}$ & $\begin{array}{c}75.4 \\
56\end{array}$ \\
\hline $\begin{array}{l}\text { ER-EC-7 } \\
\text { ER-EC-7 }\end{array}$ & $\begin{array}{l}\text { 21-Jul-03 } \\
\text { 5-Jun-00 }\end{array}$ & $\begin{array}{l}8.0 \\
7.9\end{array}$ & $\begin{array}{l}27.3 \\
30.0\end{array}$ & $\begin{array}{l}263 \\
315\end{array}$ & $\begin{array}{c}86.5 \\
118.8\end{array}$ & $\begin{array}{l}1.2 \\
1.3\end{array}$ & $\begin{array}{l}3.8 \\
5.2\end{array}$ & $\begin{array}{c}<0.03 \\
\text { n.d. }\end{array}$ & $\begin{array}{l}5.6 \\
5.8\end{array}$ & $\begin{array}{c}13.6 \\
15\end{array}$ \\
\hline $\begin{array}{l}\text { ER-EC-8 } \\
\text { ER-EC-8 }\end{array}$ & $\begin{array}{c}\text { 1-Jul-03 } \\
\text { 12-Jul-00 }\end{array}$ & $\begin{array}{l}8.1 \\
8.0\end{array}$ & $\begin{array}{l}36.7 \\
38.2\end{array}$ & $\begin{array}{l}642 \\
647\end{array}$ & $\begin{array}{l}173.8 \\
172.1\end{array}$ & $\begin{array}{l}5.2 \\
5.5\end{array}$ & $\begin{array}{l}47.3 \\
57.6\end{array}$ & $\begin{array}{c}1.0 \\
0.39\end{array}$ & $\begin{array}{l}1.4 \\
1.3\end{array}$ & $\begin{array}{c}76.1 \\
94\end{array}$ \\
\hline $\begin{array}{l}\text { ER-18-2 } \\
\text { ER-18-2 }\end{array}$ & $\begin{array}{l}\text { 17-Jun-03 } \\
21-\text { Mar-00 }\end{array}$ & $\begin{array}{l}7.9 \\
7.6\end{array}$ & $\begin{array}{l}43.0 \\
55.2\end{array}$ & $\begin{array}{l}1277 \\
1439\end{array}$ & $\begin{array}{l}881.0 \\
871.0\end{array}$ & $\begin{array}{l}12.5 \\
12.6\end{array}$ & $\begin{array}{l}12.3 \\
13.3\end{array}$ & $\begin{array}{l}<0.2 \\
\text { n.d. }\end{array}$ & $\begin{array}{l}<0.2 \\
<1.0\end{array}$ & $\begin{array}{c}52.9 \\
53\end{array}$ \\
\hline
\end{tabular}

A dashed line indicates that no measurement was recorded for the listed parameter; Cond. = Conductivity 
Table 3. Major ion chemistry and trace element data. Note that concentrations are listed in units of milligrams, micrograms, or picograms.

\begin{tabular}{|c|c|c|c|c|c|c|c|c|c|c|c|c|c|c|c|c|c|c|c|c|}
\hline Well name & Sample date & $\begin{array}{c}\mathrm{Na} \\
(\mathrm{mg} / \mathrm{L}) \\
\end{array}$ & $\begin{array}{c}\mathrm{K} \\
(\mathrm{mg} / \mathrm{L}) \\
\end{array}$ & $\begin{array}{c}\mathrm{Ca} \\
(\mathrm{mg} / \mathrm{L}) \\
\end{array}$ & $\begin{array}{c}\mathrm{Mg} \\
(\mathrm{mg} / \mathrm{L}) \\
\end{array}$ & $\begin{array}{c}\mathrm{Al} \\
(\mathrm{mg} / \mathrm{L}) \\
\end{array}$ & $\begin{array}{c}\text { As } \\
(\mu \mathrm{g} / \mathrm{L}) \\
\end{array}$ & $\begin{array}{c}\text { B } \\
\text { (mg/L) } \\
\end{array}$ & $\begin{array}{c}\mathrm{Ba} \\
(\mathrm{mg} / \mathrm{L}) \\
\end{array}$ & $\begin{array}{c}\mathrm{Fe} \\
(\mathrm{mg} / \mathrm{L}) \\
\end{array}$ & $\begin{array}{c}\text { I } \\
(\mu \mathrm{g} / \mathrm{L}) \\
\end{array}$ & $\begin{array}{c}\mathrm{Li} \\
\text { (mg/L) } \\
\end{array}$ & $\begin{array}{c}\text { Mn } \\
(\mu \mathrm{g} / \mathrm{L}) \\
\end{array}$ & $\begin{array}{c}\text { Mo } \\
(\mu \mathrm{g} / \mathrm{L}) \\
\end{array}$ & $\begin{array}{c}\mathrm{Pb} \\
(\mu \mathrm{g} / \mathrm{L}) \\
\end{array}$ & $\begin{array}{c}\mathrm{Pu} \\
\text { (pg/L) } \\
\end{array}$ & $\begin{array}{c}\text { Se } \\
(\mu \mathrm{g} / \mathrm{L}) \\
\end{array}$ & $\begin{array}{c}\mathrm{Si} \\
(\mathrm{mg} / \mathrm{L}) \\
\end{array}$ & $\begin{array}{c}\mathrm{Sr} \\
(\mu \mathrm{g} / \mathrm{L}) \\
\end{array}$ & $\begin{array}{c}\mathbf{U} \\
(\mu \mathrm{g} / \mathrm{L}) \\
\end{array}$ \\
\hline \multicolumn{21}{|c|}{ Frenchman Flat } \\
\hline $\begin{array}{l}\text { ER-5-4 \#2 } \\
\text { Yucca Flat }\end{array}$ & 21-Nov-02 & 334 & 4.3 & 0.7 & 0.3 & 1.9 & $<20$ & --- & 0.008 & 0.57 & --- & 0.07 & 98 & 82 & $<14$ & --- & $<24$ & 34.7 & 3.3 & 36.4 \\
\hline ER-2-1 & 03-Sep-03 & 73.0 & 3.8 & 3.1 & 0.3 & 0.06 & $<20$ & --- & 0.009 & 2.2 & 5.3 & 0.02 & 110 & $<3$ & $<14$ & --- & 40 & 55.8 & 6.7 & 3.40 \\
\hline ER-6-1 \#2 & 16-Jan-03 & 47.1 & 6.3 & 33.6 & 14.0 & $<0.05$ & $<20$ & 0.07 & 0.16 & $<0.04$ & --- & 0.06 & 7 & $<3$ & $<14$ & --- & $<24$ & 16.4 & 208 & 3.21 \\
\hline ER-7-1 & 17-Jul-03 & 41.6 & 5.6 & 27.1 & 13.3 & $<0.05$ & $<20$ & --- & 0.23 & $<0.04$ & 8.1 & 0.04 & $<6$ & 10 & $<14$ & --- & $<24$ & 18.3 & 156 & 1.42 \\
\hline \multicolumn{21}{|c|}{ Pahute Mesa - Oasis Valley } \\
\hline $\begin{array}{l}\text { ER-EC-1 } \\
\text { ER-EC-1 }\end{array}$ & $\begin{array}{l}\text { 3-Jun-03 } \\
\text { 1-Feb-00 }\end{array}$ & $\begin{array}{c}143.7 \\
154\end{array}$ & $\begin{array}{l}4.9 \\
6.0\end{array}$ & $\begin{array}{l}18.7 \\
19.0\end{array}$ & $\begin{array}{l}0.4 \\
0.4\end{array}$ & $\begin{array}{l}0.17 \\
<0.4\end{array}$ & $\begin{array}{l}<20 \\
---\end{array}$ & $\begin{array}{l}1.23 \\
0.34\end{array}$ & $\begin{array}{c}0.001 \\
---\end{array}$ & $\begin{array}{c}<0.04 \\
0.64\end{array}$ & -- & $\begin{array}{l}0.11 \\
0.15\end{array}$ & $\begin{array}{l}<6 \\
---\end{array}$ & $\begin{array}{l}<3 \\
---\end{array}$ & $\begin{array}{l}<14 \\
---\end{array}$ & --- & $\begin{array}{l}<24 \\
---\end{array}$ & $\begin{array}{c}28.7 \\
23\end{array}$ & $\begin{array}{l}16 \\
27\end{array}$ & $\begin{array}{l}9.51 \\
8.12\end{array}$ \\
\hline $\begin{array}{l}\text { ER-EC-2A } \\
\text { ER-EC-2A }\end{array}$ & $\begin{array}{c}\text { 8-Jul-03 } \\
27-J u l-00\end{array}$ & $\begin{array}{c}127.8 \\
123\end{array}$ & $\begin{array}{l}2.2 \\
2.5\end{array}$ & $\begin{array}{c}8.7 \\
13.1\end{array}$ & $\begin{array}{l}0.2 \\
2.5\end{array}$ & $\begin{array}{c}0.14 \\
<0.11\end{array}$ & $\begin{array}{l}<20 \\
---\end{array}$ & $\begin{array}{c}1.12 \\
---\end{array}$ & $\begin{array}{c}0.015 \\
---\end{array}$ & $\begin{array}{l}<0.04 \\
0.25\end{array}$ & -- & $\begin{array}{l}0.15 \\
0.14\end{array}$ & $\begin{array}{l}<6 \\
---\end{array}$ & $\begin{array}{c}6.8 \\
---\end{array}$ & $\begin{array}{l}<14 \\
--\end{array}$ & -- & $\begin{array}{l}<24 \\
---\end{array}$ & $\begin{array}{c}26.5 \\
15\end{array}$ & $\begin{array}{l}28 \\
74\end{array}$ & $\begin{array}{l}7.05 \\
9.20\end{array}$ \\
\hline $\begin{array}{l}\text { ER-EC-4 } \\
\text { ER-EC-4 }\end{array}$ & $\begin{array}{l}24-J u n-03 \\
17-A u g-00\end{array}$ & $\begin{array}{c}118.7 \\
116\end{array}$ & $\begin{array}{l}8.1 \\
8.7\end{array}$ & $\begin{array}{l}26.1 \\
25.9\end{array}$ & $\begin{array}{l}5.0 \\
3.8\end{array}$ & $\begin{array}{c}0.15 \\
<0.11\end{array}$ & $\begin{array}{l}<20 \\
---\end{array}$ & $\begin{array}{c}1.16 \\
---\end{array}$ & $\begin{array}{c}0.002 \\
---\end{array}$ & $\begin{array}{l}0.05 \\
0.18\end{array}$ & -- & $\begin{array}{l}0.09 \\
0.09\end{array}$ & $\begin{array}{l}<6 \\
---\end{array}$ & $\begin{array}{l}4.7 \\
---\end{array}$ & $\begin{array}{l}<14 \\
---\end{array}$ & --- & $\begin{array}{l}<24 \\
---\end{array}$ & $\begin{array}{c}40.3 \\
21\end{array}$ & $\begin{array}{l}136 \\
160\end{array}$ & $\begin{array}{l}4.08 \\
4.10\end{array}$ \\
\hline $\begin{array}{l}\text { ER-EC-5 } \\
\text { ER-EC-5 }\end{array}$ & $\begin{array}{c}\text { 15-Jul-03 } \\
25-\text { May-00 }\end{array}$ & $\begin{array}{c}70.8 \\
75\end{array}$ & $\begin{array}{l}1.1 \\
1.8\end{array}$ & $\begin{array}{l}19.8 \\
21.0\end{array}$ & $\begin{array}{l}0.8 \\
0.6\end{array}$ & $\begin{array}{l}<0.05 \\
0.24\end{array}$ & $\begin{array}{l}<20 \\
---\end{array}$ & $\begin{array}{c}1.13 \\
---\end{array}$ & $\begin{array}{c}0.003 \\
---\end{array}$ & $\begin{array}{c}<0.04 \\
0.13\end{array}$ & --- & $\begin{array}{l}0.09 \\
0.01\end{array}$ & $\begin{array}{l}<6 \\
---\end{array}$ & $\begin{array}{c}6.2 \\
---\end{array}$ & $\begin{array}{c}<14 \\
---\end{array}$ & -- & $\begin{array}{l}<24 \\
---\end{array}$ & $\begin{array}{c}24.5 \\
15\end{array}$ & $\begin{array}{l}128 \\
170\end{array}$ & $\begin{array}{l}3.34 \\
3.30\end{array}$ \\
\hline $\begin{array}{l}\text { ER-EC-6 } \\
\text { ER-EC-6 }\end{array}$ & $\begin{array}{l}10-J u n-03 \\
10-F e b-00\end{array}$ & $\begin{array}{c}119.6 \\
128\end{array}$ & $\begin{array}{l}1.8 \\
2.0\end{array}$ & $\begin{array}{l}4.6 \\
4.0\end{array}$ & $\begin{array}{l}0.2 \\
0.0\end{array}$ & $\begin{array}{l}0.18 \\
<0.4\end{array}$ & $\begin{array}{l}<20 \\
---\end{array}$ & $\begin{array}{l}1.08 \\
0.19\end{array}$ & $\begin{array}{c}0.002 \\
---\end{array}$ & $\begin{array}{c}<0.04 \\
0.42\end{array}$ & -- & $\begin{array}{c}0.1 \\
0.15\end{array}$ & $\begin{array}{l}<6 \\
---\end{array}$ & $\begin{array}{l}<3 \\
---\end{array}$ & $\begin{array}{l}<14 \\
---\end{array}$ & --- & $\begin{array}{l}<24 \\
---\end{array}$ & $\begin{array}{c}27.4 \\
22\end{array}$ & $\begin{array}{r}4.1 \\
14\end{array}$ & $\begin{array}{l}5.43 \\
4.72\end{array}$ \\
\hline $\begin{array}{l}\text { ER-EC-7 } \\
\text { ER-EC-7 }\end{array}$ & $\begin{array}{l}21-J u l-03 \\
5-J u n-00\end{array}$ & $\begin{array}{c}28.0 \\
35\end{array}$ & $\begin{array}{l}2.0 \\
2.8\end{array}$ & $\begin{array}{l}20.2 \\
22.0\end{array}$ & $\begin{array}{l}2.2 \\
2.0\end{array}$ & $\begin{array}{l}<0.05 \\
0.42\end{array}$ & $\begin{array}{l}<20 \\
---\end{array}$ & -- & $\begin{array}{c}0.004 \\
---\end{array}$ & $\begin{array}{c}<0.04 \\
0.23\end{array}$ & --- & $\begin{array}{l}0.02 \\
0.04\end{array}$ & $\begin{array}{l}<6 \\
---\end{array}$ & $\begin{array}{l}2.4 \\
---\end{array}$ & $\begin{array}{c}<14 \\
---\end{array}$ & --- & $\begin{array}{l}<24 \\
---\end{array}$ & $\begin{array}{c}20.7 \\
13\end{array}$ & $\begin{array}{c}81 \\
160\end{array}$ & $\begin{array}{l}1.86 \\
2.10\end{array}$ \\
\hline $\begin{array}{l}\text { ER-EC-8 } \\
\text { ER-EC-8 }\end{array}$ & $\begin{array}{c}1-J u l-03 \\
12-J u l-00\end{array}$ & $\begin{array}{c}120.4 \\
120\end{array}$ & $\begin{array}{l}4.9 \\
5.6\end{array}$ & $\begin{array}{l}10.1 \\
11.0\end{array}$ & $\begin{array}{l}0.3 \\
0.5\end{array}$ & $\begin{array}{c}<0.05 \\
0.21\end{array}$ & $\begin{array}{l}<20 \\
---\end{array}$ & $\begin{array}{c}0.61 \\
---\end{array}$ & $\begin{array}{c}0.002 \\
---\end{array}$ & $\begin{array}{c}<0.04 \\
0.11\end{array}$ & -- & $\begin{array}{l}0.15 \\
0.15\end{array}$ & $\begin{array}{l}<6 \\
---\end{array}$ & 10 & $\begin{array}{l}<14 \\
---\end{array}$ & --- & $\begin{array}{l}<24 \\
---\end{array}$ & $\begin{array}{c}28.4 \\
22\end{array}$ & $\begin{array}{l}22 \\
41\end{array}$ & $\begin{array}{l}4.81 \\
4.80\end{array}$ \\
\hline $\begin{array}{l}\text { ER-18-2 } \\
\text { ER-18-2 }\end{array}$ & $\begin{array}{l}\text { 17-Jun-03 } \\
21-M a r-00\end{array}$ & \begin{tabular}{|c}
344.0 \\
365
\end{tabular} & $\begin{array}{l}2.1 \\
1.8\end{array}$ & $\begin{array}{l}5.9 \\
6.1\end{array}$ & $\begin{array}{l}0.5 \\
0.2\end{array}$ & $\begin{array}{l}0.25 \\
<0.4\end{array}$ & 42 & $\begin{array}{l}1.35 \\
0.36\end{array}$ & $\begin{array}{c}0.015 \\
---\end{array}$ & $\begin{array}{c}<0.04 \\
0.06\end{array}$ & --- & $\begin{array}{l}0.22 \\
0.28\end{array}$ & $\begin{array}{l}25 \\
---\end{array}$ & $\begin{array}{l}7.8 \\
---\end{array}$ & $\begin{array}{l}<14 \\
---\end{array}$ & -- & $\begin{array}{l}27 \\
---\end{array}$ & $\begin{array}{c}26.1 \\
22\end{array}$ & $\begin{array}{l}212 \\
230\end{array}$ & $\begin{array}{l}8.53 \\
7.26\end{array}$ \\
\hline
\end{tabular}

A dashed line indicates that no measurement was recorded for the listed parameter 
Table 4. Stable isotope and noble gas data.

\begin{tabular}{|c|c|c|c|c|c|c|c|c|c|c|c|c|c|}
\hline Well name & Sample date & $\begin{array}{c}\delta \mathrm{D}_{\text {smow }} \\
(\%)\end{array}$ & $\begin{array}{c}\delta^{18} \mathrm{O}_{\text {smow }} \\
(\%)\end{array}$ & $\begin{array}{c}\delta^{13} \mathrm{C}_{\mathrm{PDB}} \\
(\%)\end{array}$ & $\begin{array}{c}{ }^{3} \mathrm{He} \\
\text { (atoms/g) }\end{array}$ & $\begin{array}{c}{ }^{4} \mathrm{He} \\
\text { (atoms/g) }\end{array}$ & $\begin{array}{c}\mathbf{R} / \mathbf{R}_{\mathbf{a}} \\
\left({ }^{3} \mathrm{He} /{ }^{4} \mathrm{He}\right. \\
\text { sample/air) }\end{array}$ & $\begin{array}{c}{ }^{20} \mathrm{Ne} \\
\text { (atoms/g) }\end{array}$ & $\begin{array}{c}{ }^{40} \mathrm{Ar} \\
\text { (atoms/g) }\end{array}$ & $\begin{array}{c}\mathrm{Kr} \\
\text { (atoms/g) }\end{array}$ & $\begin{array}{l}{ }^{130} \mathrm{Xe} \\
\text { (atoms/g) }\end{array}$ & $\begin{array}{c}{ }^{87} \mathrm{Srl}{ }^{86} \mathrm{Sr} \\
\text { (ratio) }\end{array}$ & $\begin{array}{l}\delta^{87} \mathrm{Sr} \\
(\%)\end{array}$ \\
\hline \multicolumn{14}{|l|}{ Frenchman Flat } \\
\hline $\begin{array}{l}\text { ER-5-4 \#2 } \\
\text { Yucca Flat }\end{array}$ & 21-Nov-02 & -101 & -13.3 & +0.2 & $1.65 E+06$ & $1.35 \mathrm{E}+12$ & 0.89 & $4.98 \mathrm{E}+12$ & $8.25 E+15$ & $1.81 \mathrm{E}+12$ & $2.43 E+11$ & 0.70902 & -0.25 \\
\hline ER-2-1 & 03-Sep-03 & -109.5 & -14.2 & -12.1 & $7.36 \mathrm{E}+07$ & $3.76 \mathrm{E}+12$ & 14.2 & $7.65 \mathrm{E}+12$ & $9.66 \mathrm{E}+15$ & $2.02 E+12$ & $2.62 E+11$ & 0.71210 & 4.09 \\
\hline ER-6-1 \#2 & 16-Jan-03 & -105 & -14.1 & -5.9 & --- & --- & --- & --- & --- & --- & --- & 0.71295 & 5.29 \\
\hline ER-7-1 & 17-Jul-03 & -106 & -14.1 & -5.8 & $3.28 \mathrm{E}+07$ & $4.07 \mathrm{E}+13$ & 0.58 & $4.79 \mathrm{E}+12$ & $7.44 \mathrm{E}+15$ & $1.81 \mathrm{E}+12$ & $2.66 \mathrm{E}+11$ & 0.71306 & 5.44 \\
\hline \multicolumn{14}{|c|}{ Pahute Mesa-Oasis Valley } \\
\hline $\begin{array}{l}\text { ER-EC-1 } \\
\text { ER-EC-1 }\end{array}$ & $\begin{array}{l}\text { 3-Jun-03 } \\
\text { 1-Feb-00 }\end{array}$ & $\begin{array}{l}-116 \\
-116\end{array}$ & $\begin{array}{l}-14.9 \\
-14.8\end{array}$ & $\begin{array}{l}-3.1 \\
-4.0\end{array}$ & $\begin{array}{l}9.44 E+06 \\
9.03 E+06\end{array}$ & $\begin{array}{l}1.13 E+13 \\
9.24 E+12\end{array}$ & $\begin{array}{l}0.60 \\
0.71\end{array}$ & $\begin{array}{l}7.22 \mathrm{E}+12 \\
9.93 \mathrm{E}+12\end{array}$ & $\begin{array}{l}7.69 \mathrm{E}+15 \\
9.11 \mathrm{E}+15\end{array}$ & $\begin{array}{c}1.58 \mathrm{E}+12 \\
---\end{array}$ & $\begin{array}{l}2.29 E+11 \\
2.34 E+11\end{array}$ & $\begin{array}{l}0.71056 \\
0.71023\end{array}$ & $\begin{array}{l}1.92 \\
1.45\end{array}$ \\
\hline $\begin{array}{l}\text { ER-EC-2A } \\
\text { ER-EC-2A }\end{array}$ & $\begin{array}{c}\text { 8-Jul-03 } \\
\text { 27-Jul-00 }\end{array}$ & $\begin{array}{c}-116.5 \\
-116\end{array}$ & $\begin{array}{l}-14.9 \\
-14.9\end{array}$ & $\begin{array}{l}-2.0 \\
-1.5\end{array}$ & $\begin{array}{l}8.36 E+06 \\
1.03 E+07\end{array}$ & $\begin{array}{l}6.97 \mathrm{E}+12 \\
7.92 \mathrm{E}+12\end{array}$ & $\begin{array}{l}0.87 \\
0.94\end{array}$ & $\begin{array}{l}4.28 E+12 \\
1.07 E+13\end{array}$ & $\begin{array}{l}5.69 E+15 \\
1.02 E+16\end{array}$ & $\begin{array}{c}1.21 \mathrm{E}+12 \\
--\end{array}$ & $\begin{array}{c}1.93 E+11 \\
---\end{array}$ & $\begin{array}{l}0.70912 \\
0.70939\end{array}$ & $\begin{array}{l}-0.11 \\
0.26\end{array}$ \\
\hline $\begin{array}{l}\text { ER-EC-4 } \\
\text { ER-EC-4 }\end{array}$ & $\begin{array}{l}24-J u n-03 \\
17-A u g-00\end{array}$ & $\begin{array}{l}-114 \\
-115\end{array}$ & $\begin{array}{l}-14.6 \\
-14.6\end{array}$ & $\begin{array}{l}-1.1 \\
-1.5\end{array}$ & $\begin{array}{l}2.00 E+07 \\
1.83 E+07\end{array}$ & $\begin{array}{l}1.41 \mathrm{E}+13 \\
1.30 \mathrm{E}+13\end{array}$ & $\begin{array}{l}1.02 \\
1.01\end{array}$ & $\begin{array}{l}6.79 E+12 \\
7.66 E+12\end{array}$ & $\begin{array}{l}7.16 E+15 \\
8.55 E+15\end{array}$ & $\begin{array}{c}1.42 \mathrm{E}+12 \\
---\end{array}$ & $\begin{array}{c}1.97 \mathrm{E}+11 \\
---\end{array}$ & $\begin{array}{l}0.71010 \\
0.70998\end{array}$ & $\begin{array}{l}1.27 \\
1.11\end{array}$ \\
\hline $\begin{array}{l}\text { ER-EC-5 } \\
\text { ER-EC-5 }\end{array}$ & $\begin{array}{c}\text { 15-Jul-03 } \\
25-M a y-00\end{array}$ & $\begin{array}{l}-113 \\
-113\end{array}$ & $\begin{array}{l}-14.9 \\
-14.9\end{array}$ & $\begin{array}{l}-2.8 \\
-2.5\end{array}$ & $\begin{array}{l}9.77 \mathrm{E}+06 \\
1.06 \mathrm{E}+07\end{array}$ & $\begin{array}{l}6.07 \mathrm{E}+12 \\
7.09 \mathrm{E}+12\end{array}$ & $\begin{array}{l}1.16 \\
1.08\end{array}$ & $\begin{array}{l}5.23 E+12 \\
8.88 E+12\end{array}$ & $\begin{array}{l}6.54 E+15 \\
8.37 E+15\end{array}$ & $\begin{array}{c}1.34 \mathrm{E}+12 \\
---\end{array}$ & $\begin{array}{l}1.96 \mathrm{E}+11 \\
1.84 \mathrm{E}+11\end{array}$ & $\begin{array}{l}0.70916 \\
0.70912\end{array}$ & $\begin{array}{l}-0.06 \\
-0.11\end{array}$ \\
\hline $\begin{array}{l}\text { ER-EC-6 } \\
\text { ER-EC-6 }\end{array}$ & $\begin{array}{l}\text { 10-Jun-03 } \\
\text { 10-Feb-00 }\end{array}$ & $\begin{array}{l}-117 \\
-116\end{array}$ & $\begin{array}{l}-15.0 \\
-15.0\end{array}$ & $\begin{array}{l}-2.7 \\
-3.4\end{array}$ & $\begin{array}{l}1.72 \mathrm{E}+07 \\
1.76 \mathrm{E}+07\end{array}$ & $\begin{array}{l}1.79 E+13 \\
1.75 E+13\end{array}$ & $\begin{array}{l}0.69 \\
0.73\end{array}$ & $\begin{array}{l}4.76 \mathrm{E}+12 \\
6.90 \mathrm{E}+12\end{array}$ & $\begin{array}{l}6.64 E+15 \\
7.46 E+15\end{array}$ & $\begin{array}{c}1.49 \mathrm{E}+12 \\
--\end{array}$ & $\begin{array}{l}2.26 E+11 \\
2.29 E+11\end{array}$ & $\begin{array}{l}0.71038 \\
0.70982\end{array}$ & $\begin{array}{l}1.66 \\
0.88\end{array}$ \\
\hline $\begin{array}{l}\text { ER-EC-7 } \\
\text { ER-EC-7 }\end{array}$ & $\begin{array}{l}21-J u l-03 \\
5-J u n-00\end{array}$ & $\begin{array}{l}-98 \\
-98\end{array}$ & $\begin{array}{l}-13.2 \\
-13.2\end{array}$ & $\begin{array}{l}-5.5 \\
-6.3\end{array}$ & $\begin{array}{l}6.81 E+06 \\
8.81 E+06\end{array}$ & $\begin{array}{l}5.87 \mathrm{E}+12 \\
7.46 \mathrm{E}+12\end{array}$ & $\begin{array}{l}0.84 \\
0.86\end{array}$ & $\begin{array}{l}5.39 \mathrm{E}+12 \\
7.48 \mathrm{E}+12\end{array}$ & $\begin{array}{l}7.42 \mathrm{E}+15 \\
8.20 \mathrm{E}+15\end{array}$ & $\begin{array}{c}1.59 \mathrm{E}+12 \\
---\end{array}$ & $\begin{array}{l}2.22 E+11 \\
2.35 E+11\end{array}$ & $\begin{array}{l}0.70948 \\
0.70932\end{array}$ & $\begin{array}{l}0.39 \\
0.17\end{array}$ \\
\hline $\begin{array}{l}\text { ER-EC-8 } \\
\text { ER-EC-8 }\end{array}$ & $\begin{array}{c}1-J u l-03 \\
12-J u l-00\end{array}$ & $\begin{array}{l}-115 \\
-116\end{array}$ & $\begin{array}{l}-14.9 \\
-14.8\end{array}$ & $\begin{array}{l}-0.9 \\
-1.0\end{array}$ & $\begin{array}{l}5.18 E+06 \\
6.43 E+06\end{array}$ & $\begin{array}{l}3.81 \mathrm{E}+12 \\
3.69 \mathrm{E}+12\end{array}$ & $\begin{array}{l}0.98 \\
1.26\end{array}$ & $\begin{array}{l}4.68 \mathrm{E}+12 \\
5.16 \mathrm{E}+12\end{array}$ & $\begin{array}{l}5.64 E+15 \\
6.46 E+15\end{array}$ & $\begin{array}{c}1.13 E+12 \\
---\end{array}$ & $\begin{array}{c}1.64 \mathrm{E}+11 \\
---\end{array}$ & $\begin{array}{l}0.70922 \\
0.70882\end{array}$ & $\begin{array}{c}0.03 \\
-0.54\end{array}$ \\
\hline $\begin{array}{l}\text { ER-18-2 } \\
\text { ER-18-2 }\end{array}$ & $\begin{array}{l}\text { 17-Jun-03 } \\
\text { 21-Mar-00 }\end{array}$ & $\begin{array}{l}-111 \\
-112\end{array}$ & $\begin{array}{l}-14.7 \\
-14.7\end{array}$ & $\begin{array}{l}-0.5 \\
-0.7\end{array}$ & $\begin{array}{l}5.11 \mathrm{E}+08 \\
6.81 \mathrm{E}+08\end{array}$ & $\begin{array}{l}1.83 \mathrm{E}+14 \\
1.70 \mathrm{E}+14\end{array}$ & $\begin{array}{l}2.01 \\
2.89\end{array}$ & $\begin{array}{l}2.95 E+12 \\
3.83 E+12\end{array}$ & $\begin{array}{l}3.52 \mathrm{E}+15 \\
4.22 \mathrm{E}+14\end{array}$ & $\begin{array}{c}6.94 \mathrm{E}+11 \\
---\end{array}$ & $\begin{array}{c}1.08 \mathrm{E}+11 \\
---\end{array}$ & $\begin{array}{l}0.70877 \\
0.70861\end{array}$ & $\begin{array}{l}-0.61 \\
-0.84\end{array}$ \\
\hline
\end{tabular}

A dashed line indicates that no measurement was recorded for the listed parameter. 
Table 5. Radiochemical data.

\begin{tabular}{|c|c|c|c|c|c|c|c|c|c|c|c|c|c|c|}
\hline $\begin{array}{l}\text { Well name } \\
\text { Unit } \\
\text { Half-life (a) } \\
\text { Ref. date } \\
\end{array}$ & $\begin{array}{l}\text { Sample } \\
\text { date } \\
\text { date } \\
\text { collected } \\
\text { in field }\end{array}$ & $\begin{array}{c}{ }^{3} \mathrm{H} \\
(\mathrm{pCi} / \mathrm{L}) \\
12.32 \\
\text { collect. }\end{array}$ & $\begin{array}{c}{ }^{14} \mathrm{C} \\
(\mathrm{pmc}) \\
5730 \\
\text { collect. }\end{array}$ & $\begin{array}{c}{ }^{14} \mathrm{C} \\
(\mathrm{pCi} / \mathrm{L}) \\
5730 \\
\text { collect. }\end{array}$ & $\begin{array}{l}{ }^{36} \mathrm{Cl} / \mathrm{Cl} \\
\text { (ratio) }\end{array}$ & $\begin{array}{c}{ }^{36} \mathrm{Cl} \\
(\mathrm{pCi} / \mathrm{L}) \\
3.01 \mathrm{E}+05 \\
\text { collect. }\end{array}$ & $\begin{array}{l}{ }^{129} I^{127} I \\
\text { (ratio) }\end{array}$ & $\begin{array}{c}{ }^{234} \mathrm{U} I^{238} \mathrm{U} \\
\text { (ratio) }\end{array}$ & $\begin{array}{c}{ }^{234} \mathrm{U} /{ }^{238} \mathrm{U} \\
\text { activity } \\
\text { ratio } \\
\text { (ratio) }\end{array}$ & $\begin{array}{c}{ }^{234} U I^{235} U \\
\text { (ratio) }\end{array}$ & $\begin{array}{c}{ }^{235} \mathrm{U} I^{238} \mathrm{U} \\
\text { (ratio) }\end{array}$ & $\begin{array}{c}{ }^{234} \mathrm{U} \\
(\mathrm{pCi} / \mathrm{L}) \\
2.46 \mathrm{E}+05 \\
\text { collect. }\end{array}$ & $\begin{array}{c}{ }^{235} \mathrm{U} \\
\text { (pCi/L) } \\
7.04 \mathrm{E}+08 \\
\text { collect. }\end{array}$ & $\begin{array}{c}{ }^{238} \mathrm{U} \\
(p \mathrm{Ci} / \mathrm{L}) \\
4.47 \mathrm{E}+09 \\
\text { collect. }\end{array}$ \\
\hline \multicolumn{15}{|c|}{ Frenchman Flat } \\
\hline $\begin{array}{l}\text { ER-5-4 \#2 } \\
\text { Yucca Flat }\end{array}$ & 21-Nov-02 & 156.8 & 1.0 & 4.69E-03 & 1.76E-13 & 3.0E-04 & --- & 7.150E-05 & 1.31 & $9.919 E-03$ & $7.248 \mathrm{E}-03$ & 16.12 & 0.57 & 12.15 \\
\hline ER-2-1 & 03-Sep-03 & 227.7 & 18.2 & 4.14E-02 & $7.19 \mathrm{E}-13$ & $1.04 \mathrm{E}-04$ & $<5 \mathrm{E}-10$ & $1.482 \mathrm{E}-04$ & 2.71 & 2.043E-02 & $7.252 \mathrm{E}-03$ & 3.11 & 0.053 & 1.136 \\
\hline ER-6-1 \#2 & 16-Jan-03 & $\leq 30.8$ & 2.4 & 7.39E-03 & 4.33E-13 & $1.4 \mathrm{E}-04$ & --- & 2.299E-04 & 4.19 & 3.171E-02 & $7.248 \mathrm{E}-03$ & 4.55 & 0.05 & 1.07 \\
\hline ER-7-1 & 17-Jul-03 & 117.2 & 5.3 & $1.56 \mathrm{E}-02$ & 3.77E-13 & $1.18 \mathrm{E}-04$ & $<1$ E-09 & $1.876 \mathrm{E}-04$ & 3.43 & $2.586 \mathrm{E}-02$ & $7.254 \mathrm{E}-03$ & 1.33 & 0.018 & 0.383 \\
\hline ER-12-2 & 01-Apr-03 & 4.3 & 1.5 & $5.39 \mathrm{E}-03$ & $6.90 \mathrm{E}-13$ & $1.6 \mathrm{E}-04$ & -- & $1.788 \mathrm{E}-04$ & 3.26 & $2.449 \mathrm{E}-02$ & 7.303E-03 & 0.019 & 2.7E-04 & 5.7E-03 \\
\hline \multicolumn{15}{|c|}{ Pahute Mesa-Oasis Valley } \\
\hline $\begin{array}{l}\text { ER-EC-1 } \\
\text { ER-EC-1 }\end{array}$ & $\begin{array}{l}\text { 3-Jun-03 } \\
\text { 1-Feb-00 }\end{array}$ & $\begin{array}{l}\leq 174 \\
<1.5\end{array}$ & $\begin{array}{l}7.2 \\
5.9\end{array}$ & $\begin{array}{l}1.28 \mathrm{E}-02 \\
1.05 \mathrm{E}-02\end{array}$ & $\begin{array}{l}5.14 \mathrm{E}-13 \\
5.46 \mathrm{E}-13\end{array}$ & $\begin{array}{l}1.64 \mathrm{E}-03 \\
1.75 \mathrm{E}-03\end{array}$ & -- & $\begin{array}{l}1.94 \mathrm{E}-04 \\
2.10 \mathrm{E}-04\end{array}$ & $\begin{array}{l}3.54 \\
3.82\end{array}$ & $\begin{array}{l}2.663 \mathrm{E}-02 \\
2.893 \mathrm{E}-02\end{array}$ & $\begin{array}{l}7.269 \mathrm{E}-03 \\
7.254 \mathrm{E}-03\end{array}$ & $\begin{array}{l}11.3 \\
10.5\end{array}$ & $\begin{array}{l}0.148 \\
0.126\end{array}$ & $\begin{array}{l}3.17 \\
2.71\end{array}$ \\
\hline $\begin{array}{l}\text { ER-EC-2A } \\
\text { ER-EC-2A }\end{array}$ & $\begin{array}{c}\text { 8-Jul-03 } \\
\text { 27-Jul-00 }\end{array}$ & $\begin{array}{l}\leq 93 \\
<1.5\end{array}$ & $\begin{array}{l}7.7 \\
7.7\end{array}$ & $\begin{array}{l}1.52 \mathrm{E}-02 \\
1.58 \mathrm{E}-02\end{array}$ & $\begin{array}{l}5.02 \mathrm{E}-13 \\
5.33 \mathrm{E}-13\end{array}$ & $\begin{array}{l}9.15 \mathrm{E}-04 \\
1.11 \mathrm{E}-03\end{array}$ & -- & $\begin{array}{l}2.74 \mathrm{E}-04 \\
2.25 \mathrm{E}-04\end{array}$ & $\begin{array}{l}5.01 \\
4.11\end{array}$ & $\begin{array}{l}3.781 \mathrm{E}-02 \\
3.090 \mathrm{E}-02\end{array}$ & $\begin{array}{l}7.254 \mathrm{E}-03 \\
7.273 \mathrm{E}-03\end{array}$ & $\begin{array}{l}11.9 \\
12.8\end{array}$ & $\begin{array}{l}0.110 \\
0.144\end{array}$ & $\begin{array}{l}2.35 \\
3.08\end{array}$ \\
\hline $\begin{array}{l}\text { ER-EC-4 } \\
\text { ER-EC-4 }\end{array}$ & $\begin{array}{l}\text { 24-Jun-03 } \\
17-A u g-00\end{array}$ & $\begin{array}{l}<1.5 \\
<1.5\end{array}$ & $\begin{array}{l}5.9 \\
5.0\end{array}$ & $\begin{array}{l}1.07 \mathrm{E}-02 \\
9.54 \mathrm{E}-03\end{array}$ & $\begin{array}{l}4.80 \mathrm{E}-13 \\
5.61 \mathrm{E}-13\end{array}$ & $\begin{array}{l}1.28 \mathrm{E}-03 \\
1.77 \mathrm{E}-03\end{array}$ & --- & $\begin{array}{l}1.59 \mathrm{E}-04 \\
1.59 \mathrm{E}-04\end{array}$ & $\begin{array}{l}2.90 \\
2.90\end{array}$ & $\begin{array}{l}2.188 \mathrm{E}-02 \\
2.175 \mathrm{E}-02\end{array}$ & $\begin{array}{l}7.268 \mathrm{E}-03 \\
7.289 \mathrm{E}-03\end{array}$ & $\begin{array}{l}3.99 \\
3.97\end{array}$ & $\begin{array}{l}0.064 \\
0.064\end{array}$ & $\begin{array}{l}1.36 \\
1.39\end{array}$ \\
\hline $\begin{array}{l}\text { ER-EC-5 } \\
\text { ER-EC-5 }\end{array}$ & $\begin{array}{c}\text { 15-Jul-03 } \\
\text { 25-May-00 }\end{array}$ & $\begin{array}{l}\leq 9.0 \\
<1.5\end{array}$ & $\begin{array}{l}7.5 \\
6.3\end{array}$ & $\begin{array}{l}1.62 \mathrm{E}-02 \\
1.33 \mathrm{E}-02\end{array}$ & $\begin{array}{l}5.61 \mathrm{E}-13 \\
6.53 \mathrm{E}-13\end{array}$ & $\begin{array}{c}2.95 \mathrm{E}-04 \\
3.5 \mathrm{E}-04\end{array}$ & -- & $\begin{array}{l}3.53 \mathrm{E}-04 \\
3.51 \mathrm{E}-04\end{array}$ & $\begin{array}{l}6.45 \\
6.41\end{array}$ & $\begin{array}{l}4.852 E-02 \\
4.823 E-02\end{array}$ & $\begin{array}{l}7.272 \mathrm{E}-03 \\
7.277 \mathrm{E}-03\end{array}$ & $\begin{array}{l}7.27 \\
7.20\end{array}$ & $\begin{array}{l}0.052 \\
0.052\end{array}$ & $\begin{array}{l}1.12 \\
1.11\end{array}$ \\
\hline $\begin{array}{l}\text { ER-EC-6 } \\
\text { ER-EC-6 }\end{array}$ & $\begin{array}{l}\text { 10-Jun-03 } \\
\text { 10-Feb-00 }\end{array}$ & $\begin{array}{l}\leq 64 \\
<1.5\end{array}$ & $\begin{array}{l}6.6 \\
5.4\end{array}$ & $\begin{array}{l}1.17 \mathrm{E}-02 \\
9.86 \mathrm{E}-03\end{array}$ & $\begin{array}{l}5.07 \mathrm{E}-13 \\
5.41 \mathrm{E}-13\end{array}$ & $\begin{array}{c}8.65 \mathrm{E}-04 \\
7.9 \mathrm{E}-04\end{array}$ & -- & $\begin{array}{l}2.03 E-04 \\
2.23 E-04\end{array}$ & $\begin{array}{l}3.71 \\
4.07\end{array}$ & $\begin{array}{l}2.795 E-02 \\
3.073 E-02\end{array}$ & $\begin{array}{l}7.265 \mathrm{E}-03 \\
7.272 \mathrm{E}-03\end{array}$ & $\begin{array}{l}6.79 \\
6.52\end{array}$ & $\begin{array}{l}0.085 \\
0.074\end{array}$ & $\begin{array}{l}1.81 \\
1.58\end{array}$ \\
\hline $\begin{array}{l}\text { ER-EC-7 } \\
\text { ER-EC-7 }\end{array}$ & $\begin{array}{l}21-J u l-03 \\
5-J u n-00\end{array}$ & $\begin{array}{c}1.6 \\
<1.5\end{array}$ & $\begin{array}{l}46.2 \\
36.5\end{array}$ & $\begin{array}{l}4.80 \mathrm{E}-02 \\
5.22 \mathrm{E}-02\end{array}$ & $\begin{array}{l}7.55 \mathrm{E}-13 \\
1.18 \mathrm{E}-12\end{array}$ & $\begin{array}{c}9.47 \mathrm{E}-05 \\
2.0 \mathrm{E}-04\end{array}$ & -- & $\begin{array}{l}3.97 E-04 \\
3.97 E-04\end{array}$ & $\begin{array}{l}7.26 \\
7.26\end{array}$ & $\begin{array}{l}5.478 \mathrm{E}-02 \\
5.458 \mathrm{E}-02\end{array}$ & $\begin{array}{l}7.253 E-03 \\
7.283 E-03\end{array}$ & $\begin{array}{l}4.57 \\
8.17\end{array}$ & $\begin{array}{l}0.029 \\
0.033\end{array}$ & $\begin{array}{c}0.622 \\
0.71\end{array}$ \\
\hline $\begin{array}{l}\text { ER-EC-8 } \\
\text { ER-EC-8 }\end{array}$ & $\begin{array}{c}\text { 1-Jul-03 } \\
\text { 12-Jul-00 }\end{array}$ & $\begin{array}{c}5.4 \\
<1.5\end{array}$ & $\begin{array}{l}8.0 \\
8.7\end{array}$ & $\begin{array}{l}1.68 \mathrm{E}-02 \\
1.80 \mathrm{E}-02\end{array}$ & $\begin{array}{l}4.90 \mathrm{E}-13 \\
4.63 \mathrm{E}-13\end{array}$ & $\begin{array}{c}7.65 \mathrm{E}-04 \\
8.8 \mathrm{E}-04\end{array}$ & -- & $\begin{array}{l}2.77 \mathrm{E}-04 \\
2.78 \mathrm{E}-04\end{array}$ & $\begin{array}{l}5.06 \\
5.08\end{array}$ & $\begin{array}{l}3.822 \mathrm{E}-02 \\
3.821 \mathrm{E}-02\end{array}$ & $\begin{array}{l}7.242 \mathrm{E}-03 \\
7.276 \mathrm{E}-03\end{array}$ & $\begin{array}{l}8.22 \\
8.18\end{array}$ & $\begin{array}{l}0.075 \\
0.074\end{array}$ & $\begin{array}{l}1.61 \\
1.59\end{array}$ \\
\hline $\begin{array}{l}\text { ER-18-2 } \\
\text { ER-18-2 }\end{array}$ & $\begin{array}{l}\text { 17-Jun-03 } \\
\text { 21-Mar-00 }\end{array}$ & $\begin{array}{l}<1.5 \\
<1.5\end{array}$ & $\begin{array}{l}0.4 \\
1.6\end{array}$ & $\begin{array}{l}4.13 \mathrm{E}-03 \\
1.70 \mathrm{E}-02\end{array}$ & $\begin{array}{l}2.31 \mathrm{E}-13 \\
3.02 \mathrm{E}-13\end{array}$ & $\begin{array}{c}9.38 \mathrm{E}-05 \\
1.3 \mathrm{E}-04\end{array}$ & --- & $\begin{array}{l}6.98 \mathrm{E}-04 \\
6.95 \mathrm{E}-04\end{array}$ & $\begin{array}{l}12.76 \\
12.70\end{array}$ & $\begin{array}{l}9.585 \mathrm{E}-02 \\
9.563 \mathrm{E}-02\end{array}$ & $\begin{array}{l}\text { 7.287E-03 } \\
7.269 \mathrm{E}-03\end{array}$ & $\begin{array}{l}36.7 \\
35.4\end{array}$ & $\begin{array}{l}0.133 \\
0.129\end{array}$ & $\begin{array}{l}2.85 \\
2.76\end{array}$ \\
\hline
\end{tabular}

A dashed line indicates that no measurement was recorded for the listed parameter. 



\title{
Chapter 3
}

\section{Radionuclide Decay and In-growth Technical Basis Document}

\author{
Annie B. Kersting, David L. Finnegan, Brad K. Esser, Andrew F. B. Tompson, \\ David K. Smith, Mavrik Zavarin, Carol J. Bruton, and Gayle A. Pawloski
}

\section{Executive Summary}

The purpose of this report is to assess the decay and in-growth of radionuclides from the radionuclide source term (RST) deposited by underground nuclear weapons tests conducted at the Nevada Test Site (NTS) from 1951 through 1992. A priority of the Underground Test Area (UGTA) project, administered by the Environmental Restoration Division of U.S. Department of Energy, Nevada Site Office, NNSA/NSO, was to determine as accurately as possible a measure of the total radionuclide inventory for calculation of the RST deposited in the subsurface at the NTS. The motivation for the development of a total radionuclide inventory is driven by a need to calculate the amount of radioactivity that will move away from the nuclear test cavities over time, referred to as the hydrologic source term (HST). The HST is a subset of the RST and must be calculated using knowledge of the radionuclide inventory, geochemistry and hydrology of the subsurface environment. Knowledge of the HST will serve the regulatory process designed to protect human health from exposures to contaminated groundwater.

Following the detonation of an underground nuclear test, and depending on the presence of water at the location of the detonation, the residual radionuclides may be found in aqueous or gaseous states, precipitated or chemically sorbed states, or incorporated in melt glass produced by the nuclear test. The decay and in-growth of radionuclides may have geochemical implications for the migration of radionuclides away from underground nuclear test cavities. For example, in the case of a long-lived mobile parent decaying to a shorter-lived and less mobile daughter, the geochemical properties of the parent radionuclide may control the distribution of the daughter nuclide. It becomes important to understand the evolution of the RST in terms of effects on the mobility, solubility, or abundance of radionuclides in the HST that are created by decay and ingrowth processes.

The total radionuclide inventory and thus the RST changes with time due to radioactive decay. The abundance of a specific radionuclide at any given time is a function of the initial amount of radioactivity, the decay rate and in-growth from parent radionuclides. The in-growth of radioactivity is the additional amount of radioactivity for a given radionuclide that comes from the decay of the parent isotopes. In this report, decay and in-growth of radionuclides from the RST are evaluated over the 1000-year time frame in order to determine whether coupled in-growth and decay affect the relative abundance of any RST radionuclide. In addition, it is also necessary to identify whether any new, 
radionuclides, not initially produced by the nuclear test, exist as the sole result of ingrowth from a parent radionuclide.

One of the major goals of this report is to simplify the transport modeler's task by pointing out where in-growth is unimportant and where it needs to be considered. The specific goals of this document are to evaluate radionuclide decay chains and provide specific recommendations for incorporating radionuclide daughters of concern in the calculation of the radionuclide inventory. An unclassified inventory of 43 radionuclides produced by 828 underground nuclear tests conducted at the NTS, subdivided into five principal geographic test centers, is presented in Bowen et al., (2001). This radionuclide inventory by Bowen et al. (2001) is the data set from which we evaluate relevant decay and in-growth of radionuclides. To this end, the following recommendations are given:

- All of the radionuclides in the radionuclide inventory with low to intermediate atomic numbers $(Z<80)$ will decay directly into stable, nonradioactive daughter products. They will not produce additional members of the radionuclide inventory.

- $\quad$ The short-lived radionuclides in decay chains with long-lived parents will exist in secular equilibrium with their parents and their abundances can be estimated from the abundance of their parent. Inclusion of the daughters as additional members of the radionuclide inventory is not necessary.

- $\quad$ There are daughters in the actinide chains, such as isotopes of radium and radon that are of concern in the environment, but the background from the decay of natural uranium dwarfs the contributions from the RST. Therefore, they do not need to be included as additional members of the radionuclide inventory.

- $\quad$ There are eight decay chains that involve long decay and in-growth patterns that are discussed in detail in this report. The following is a short summary of the radionuclides for which in-growth is important and needs to be calculated.

。 ${ }^{93} \mathrm{Zr} \rightarrow{ }^{93 m} \mathrm{Nb} \rightarrow{ }^{93} \mathrm{Nb}$ : The in-growth of ${ }^{93 m} \mathrm{Nb}$ from ${ }^{93} \mathrm{Zr}$ over 1,000 years could be significant. Over a 1000 year time frame the ${ }^{93 m} \mathrm{Nb}$ will be in secular equilibrium with ${ }^{93} \mathrm{Zr}$. Since the ${ }^{93} \mathrm{Zr}$ has a much higher initial concentration in the RST, it is possible that the in-growth of ${ }^{93 \mathrm{~m}} \mathrm{Nb}$ could be significant.

- ${ }^{150} \mathrm{Gd}$ : Gd-150, is an additional member of the radionuclide inventory that was not included in the radionuclide inventory of Bowen et al. (2001) because it is not initially produced by a nuclear test. The in-growth of ${ }^{150} \mathrm{Gd}$ should be calculated explicitly. Gd-150 is produced from the partial decay of ${ }^{150 \mathrm{~m}} \mathrm{Eu}\left(\mathrm{t}_{1 / 2}=12.6 \mathrm{hr}\right)$. Although the original concentration of ${ }^{150 \mathrm{~m}} \mathrm{Eu}$ was not estimated in the Bowen report (2001) because of its short half-life, it is approximately $30 \%$ of the total $\mathrm{Eu}\left({ }^{150} \mathrm{Eu}+{ }^{150 \mathrm{~m}} \mathrm{Eu}\right)$ produced (D.K. Smith, personal communication). 
。 ${ }^{238} \mathrm{Pu} \rightarrow{ }^{234} \mathrm{U}$ : The ${ }^{238} \mathrm{Pu}$ will decay to ${ }^{234} \mathrm{U}$ over the 1000 -year time frame considered. The in-growth of ${ }^{234} \mathrm{U}$ from ${ }^{238} \mathrm{Pu}$, natural ${ }^{238} \mathrm{U}$ and weapons related ${ }^{238} \mathrm{U}$ should be treated explicitly. This may be of consequence in tests with a small ${ }^{234} \mathrm{U}$ source term.

- ${ }^{241} \mathrm{Pu} \rightarrow{ }^{241} \mathrm{Am} \rightarrow{ }^{237} \mathrm{~Np}$ : This is probably the most important decay and in-growth chain in the RST. In-growth is important for calculating both ${ }^{241} \mathrm{Am}$ and ${ }^{237} \mathrm{~Np}$.

- ${ }^{243} \mathrm{Am} \rightarrow{ }^{239} \mathrm{~Np} \rightarrow{ }^{239} \mathrm{Pu} \rightarrow{ }^{235} \mathrm{U}$ : Although ${ }^{239} \mathrm{Pu}$ has a long halflife relative to the 1000-year time period evaluated, it has a large source term compared to ${ }^{235} \mathrm{U}$. In-growth of ${ }^{235} \mathrm{U}$ should be treated explicitly as it becomes significant just after the 1000-year time frame (Figure 7).

。 ${ }^{244} \mathrm{Cm} \rightarrow{ }^{240} \mathrm{Pu} \rightarrow{ }^{236} \mathrm{U} \rightarrow{ }^{232} \mathrm{Th}$ : The in-growth of ${ }^{240} \mathrm{Pu}$ should be treated explicitly although the contribution may be insignificant where the ${ }^{240} \mathrm{Pu}$ source term is much larger than ${ }^{244} \mathrm{Cm}$. The ingrowth of ${ }^{236} \mathrm{U}$ from ${ }^{240} \mathrm{Pu}$ must be treated explicitly.

It must be emphasized that conclusions drawn from this document are based on the 1000year time frame and the same conclusions need not hold for either shorter or longer time periods.

\section{Introduction}

The radionuclides deposited by an underground nuclear test are derived from the original fuel material in the device not consumed in the explosion, nuclear reactions driving the explosion, and activation products created in the geologic medium. Collectively, these radionuclides and their residual abundances comprise the radionuclide source term (RST). Following detonation, and depending on the presence of water at the location of the detonation, the residual radionuclides may be found in aqueous or gaseous states, precipitated or chemically sorbed states, or incorporated in melt glass produced by the test. The purpose of this report is to assess the decay and in-growth of radionuclides from the RST deposited by underground nuclear weapons tests conducted at the Nevada Test Site (NTS) from 1951 through 1992. The abundance of a radionuclide changes with time due to radioactive decay and in-growth. The in-growth of radioactivity is the additional amount of radioactivity for a given radionuclide that comes from the decay of the parent isotopes. In this report, decay and in-growth of radionuclides from the RST are evaluated over a 1000-year time frame in order to determine whether coupled in-growth and decay affect the relative abundance of any RST radionuclides. It is also necessary to identify whether any new additional, radionuclide daughters resulting from in-growth need to be included in the radionuclide inventory.

One of the major goals of this report is to simplify the transport modeler's task by pointing out where in-growth is unimportant and where it needs to be considered. The specific goals of this document are to evaluate radionuclide decay chains and provide specific recommendations for incorporating radionuclide daughters of concern in the calculation of the radionuclide inventory. An unclassified inventory of radionuclides 
produced by 828 underground nuclear tests conducted at the NTS, subdivided into five principal geographic test centers, is presented in Bowen et al., (2001). The Yucca Flat geographic test centers was further subdivided into tests below or within $100 \mathrm{~m}$ of the water table and those above. This radionuclide inventory by Bowen et al. (2001) is the data set from which we evaluate relevant decay and in-growth of radionuclides. This inventory provides a calculated estimate of radioactivity remaining underground at the NTS after underground nuclear testing ceased on September 23, 1992.

The reasons for incorporation of decay chains in the assessment of the RST are:

1) Several nuclides in the RST compiled by Lawrence Livermore (LLNL) and Los Alamos National Laboratories (LANL) (Bowen et al., 2001), radioactively decay to other radionuclides included in the inventory. Whereas the evolution of a radioactive parent is described by simple exponential decay; $N(t)=N(0) e^{-\lambda t}$ the evolution of radioactive daughters and granddaughters must include in-growth, resulting in coupled equations of the form $d N_{2}(t) / d t=N_{1}(t) \lambda_{1}-N_{2}(t) \lambda_{2}$ where; $N_{1} \stackrel{\lambda_{1}}{\longrightarrow} N_{2} \stackrel{\lambda_{2}}{\longrightarrow}$, where $\mathrm{N}=$ number of atoms, $\mathrm{t}=$ time, $\lambda=\ln (2) /$ half-life.

2) The decay of radionuclides may have geochemical implications for the migration of radionuclides away from underground nuclear test cavities. Modeling of the near-field for proposed high level waste repositories has shown that precipitation fronts may be induced by radionuclide decay and elemental solubility limits (Worgan and Apted, 1992). Implications for far-field transport are also important. For example, in the case of a long-lived mobile parent decaying to a shorter-lived and less mobile daughter, the geochemical properties of the parent radionuclide may control the distribution of the daughter nuclide.

3) Finally, certain radionuclides regulated under Federal drinking water standards (U.S. Environmental Protection Agency, 1991) and not included in the RST (e.g. ${ }^{222} \mathrm{Rn},{ }^{226} \mathrm{Ra},{ }^{228} \mathrm{Ra}$ and a number of others) are produced by the radioactive decay of RST parent nuclides. Furthermore, gross alpha and beta activities in groundwater, which are regulated under Federal drinking water standards (U.S. Environmental Protection Agency, 1991) represent the combined activities of all parent nuclides and their daughters.

\section{Sources of Radionuclide Data}

A priority of the Underground Test Area (UGTA) project, administered by the Environmental Restoration Division of U.S. Department of Energy, Nevada Site Office NNSA/NSO, was to determine as accurately as possible the total radionuclide inventory deposited in the subsurface at the NTS. The radionuclide inventory is a calculated estimate of the RST deposited underground resulting from nuclear testing and is a necessary starting point for estimations of radionuclide transport away from test locations. The initial effort to compile a total radionuclide inventory at the NTS used both measurements and calculations. The large amount of data required for this effort was collected from LLNL and LANL weapons program databases and was described in a preliminary classified report (Goishi et al., 1994). The final classified report was published in Miller et al. (2001). Because radionuclide data for individual nuclear tests 
are classified, the radionuclide inventory was subsequently divided into five geographic test centers, summed for each radionuclide of concern in each geographic test centers, and published in an unclassified report (Bowen et al., 2001).

The five principal geographic test centers used to sum the radionuclide abundances are shown in Table 1. The five test centers are similar to the areas designated as "Corrective Action Units" for groundwater remediation.

Table 1. Principal Geographic Test Centers for NTS (from Bowen et al., 2001)

\begin{tabular}{|ll|}
\hline NTS Principal Geographic Test Centers & NTS Areas Included \\
\hline & \\
Yucca Flat* & $1,2,3,4,6,7,8,9,10,15$ \\
Pahute Mesa - 19 & 19 \\
Pahute Mesa - 20 & 20 \\
Frenchman Flat & 5,11 \\
Rainier Mesa/Shoshone Mt & $12,16,18,30$ \\
\hline
\end{tabular}

* Further subdivided into tests detonated above and below water table.

Because the data in the Bowen et al. (2001) report are the basis for our decay chain analysis in this report, it is important that we restate the criteria that were used to determine which radionuclides to include in the radionuclide inventory. Not all radionuclides produced during a nuclear test are included in the radionuclide inventory. Some radionuclides have already decayed away; nuclides that have short half-lives decay to undetectable levels soon after the test. Other nuclides are produced in abundances too low to ever exceed levels deemed unsafe. For this reason the following criteria were used (Bowen et al., 2001):

1) "Excluded were nuclides produced in such low amounts that if all of the amount produced during a nuclear test were dissolved into a volume of water equal to the volume of the detonation cavity for the test, 100 years from 1992 the resulting aqueous concentration (activity) in $\mu \mathrm{Ci} / \mathrm{mL}$ (one $\mu \mathrm{Ci}=2.22 \times 10^{6}$ disintegrations per minute) would be less than one-tenth of the values for the maximum permissible concentrations (MPC's) proposed for drinking water by the U. S. Environmental Protection Agency in the Federal Register (1991).

This effectively excludes almost all radionuclides with half- lives less than ten years.

2) If a radionuclide exceeded criteria (1) for at least one test, it was included for all other tests for which estimates are available even if concentrations were below the 0.1 MPC criteria.

The MPC of a nuclide listed in this compilation is that concentration in drinking water that will impart a dose of $4 \mathrm{mrem} /$ year to a person drinking an average of 2 liters of water per day. The requirement of 100 years into the future eliminates many nuclides that are produced in great abundance in nuclear detonations but have halflives sufficiently short that they will have decayed below the $0.1 \mathrm{MPC}$ value by that time. 
3) For nuclides with no listed values, we conservatively assumed a value of $10^{-8}$ $\mathrm{Ci} / \mathrm{mL}$ for the MPC."

The 43 radionuclides that met the above criteria make up the radionuclide inventory listed in Table 1 in Bowen et al., (2001) and repeated here for completeness (Table 2). Although the radionuclide inventory includes activation products created in the host geologic medium, it does not include pre-existing, naturally occurring radionuclides, although they may become redistributed or incorporated in melt glass as a result of the test. In addition, it does not include any non-radioactive materials introduced underground by the test, even though many of these might also be considered contaminants.

Prior to the release of the Bowen et al. (2001) report, several UGTA funded studies developed criteria for selecting radionuclides for application to specific transport modeling studies. These studies used a different number of radionuclides of concern as well as slightly different numbers for the initial radioactivity. There are several reasons for this apparent lack of agreement. Some works, such as Goishi et al., (1994), Esser (1994), Smith (2001) and Pawloski et al., (2002) used curie activities and atoms decay corrected to January 1, 1994. Other works such as Miller et al. (2001) and Bowen et al. (2001), decay corrected the inventory to September 23, 1992, the last date of underground nuclear testing at the NTS. Smith (2001) used the Department of Energy classification bulletin WNP-87 prior to the release of by Bowen et al. (2001) to calculate the radionuclide inventory for all tests fired below or within $100 \mathrm{~m}$ of the water table in Areas 19 and 20 (Pahute Mesa). WNP-87 was rescinded (memo NN-52, 3/10/1998) due to being replaced by the declassification of Bowen et al. (2001). Pawloski et al. (2002) used the Smith (2001) compilation for the radionuclide inventory of the Cheshire test in Pahute Mesa. The Bowen et al. (2001) inventory did not separate the Pahute Mesa radionuclide inventory for tests detonated above and below the water table as the Smith (2001) report did. Tompson et al., (2002) used the Bowen et al. (2001) inventory for calculation of the hydrologic source term in Frenchman Flat.

In addition to reports using slightly different dates to decay correct the atoms in the RST, different numbers of radionuclides of concern were also used. Again, this apparent lack of agreement is mainly a result of different criteria and goals for the various projects. Smith (2001) used the same 43 radionuclides as Bowen et al. (2001), but split Th and U into soil and device contributions. He also footnoted the possible addition of ${ }^{150} \mathrm{Gd}$, and provided a summed inventory for ${ }^{150} \mathrm{Gd}$ that was deposited below or within $100 \mathrm{~m}$ of the water table. Tompson et al. (2002) used the 43 radionuclides from Bowen et al. (2001) but added ${ }^{150} \mathrm{Gd}$ and ${ }^{152} \mathrm{Gd}$. There is no initial abundance of ${ }^{150} \mathrm{Gd}$ as it is solely derived from the decay of ${ }^{150 \mathrm{~m}} \mathrm{Eu} .{ }^{152} \mathrm{Gd}$ is produced from the decay of ${ }^{152} \mathrm{Eu}$ and also has no initial abundance from underground nuclear testing. Pawloski et al. (2002) used the radionuclide inventory of Smith (2001) plus additional criteria to initially evaluate 52 radionuclides of concern for the Cheshire test. Although initially discussed, eight species for which groundwater measurements have been reported were ultimately not included in the Cheshire inventory because there was no reported radionuclide inventory because they do not satisfy criterion (1) in Bowen et al. (2001). All eight species evaluated have 
Table 2. Radionuclides for Inclusion into Radionuclide Inventory (from Bowen et al., 2001)

\begin{tabular}{|c|c|c|c|c|}
\hline Element & Nuclide & Half-life $(y)^{*}$ & MPC $(\mu \mathrm{Ci} / \mathbf{m L})$ & $\begin{array}{l}\text { Main Source(s) } \\
\text { (FP=fission product) }\end{array}$ \\
\hline Hydrogen & ${ }^{3} \mathrm{H}$ & 12.32 & $6.1 \times 10^{-5}$ & device component; ${ }^{6} \mathrm{Li}(\mathrm{n}, \alpha) \mathrm{T}$ \\
\hline Carbon & ${ }^{14} \mathrm{C}$ & 5715 & $3.2 \times 10^{-6}$ & ${ }^{14} \mathrm{~N}(\mathrm{n}, \mathrm{p}) ;{ }^{13} \mathrm{C}(\mathrm{n}, \gamma) ;{ }^{17} \mathrm{O}(\mathrm{n}, \alpha)$ \\
\hline Aluminum & ${ }^{26} \mathrm{~A} 1$ & $7.1 \times 10^{5}$ & ---- & ${ }^{27} \mathrm{~A} 1(\mathrm{n}, 2 \mathrm{n})$ \\
\hline Chlorine & ${ }^{36} \mathrm{C} 1$ & $3.01 \times 10^{5}$ & $1.8 \times 10^{-6}$ & ${ }^{35} \mathrm{C} 1(\mathrm{n}, \gamma) ;{ }^{39} \mathrm{~K}(\mathrm{n}, \alpha)$ \\
\hline Argon & ${ }^{39} \mathrm{Ar}$ & 269 & ---- & ${ }^{39} \mathrm{~K}(\mathrm{n}, \mathrm{p}) ;{ }^{38} \operatorname{Ar}(\mathrm{n}, \gamma)$ \\
\hline Potassium & ${ }^{40} \mathrm{~K}$ & $1.27 \times 10^{9}$ & ---- & natural \\
\hline Calcium & ${ }^{41} \mathrm{Ca}$ & $1.03 \times 10^{5}$ & ---- & ${ }^{40} \mathrm{Ca}(\mathrm{n}, \gamma)$ \\
\hline \multirow[t]{2}{*}{ Nickel } & ${ }^{59} \mathrm{Ni}$ & $7.6 \times 10^{4}$ & $2.7 \times 10^{-5}$ & ${ }^{58} \mathrm{Ni}(\mathrm{n}, \gamma)$ \\
\hline & ${ }^{63} \mathrm{Ni}$ & 100 & $9.9 \times 10^{-6}$ & ${ }^{62} \mathrm{Ni}(\mathrm{n}, \gamma),{ }^{64} \mathrm{Ni}(\mathrm{n}, 2 \mathrm{n}),{ }^{63} \mathrm{Cu}(\mathrm{n}, \mathrm{p})$ \\
\hline Krypton & ${ }^{85} \mathrm{Kr}$ & 10.76 & ---- & $\mathrm{FP} ;{ }^{84} \mathrm{Kr}(\mathrm{n}, \gamma)$ \\
\hline Strontium & ${ }^{90} \mathrm{Sr}$ & 28.78 & $4.2 \times 10^{-8}$ & $\mathrm{FP}$ \\
\hline Zirconium & ${ }^{93} \mathrm{Zr}$ & $1.5 \times 10^{6}$ & $5.1 \times 10^{-6}$ & $\mathrm{FP} ;{ }^{92} \mathrm{Zr}(\mathrm{n}, \gamma) ;{ }^{94} \mathrm{Zr}(\mathrm{n}, 2 \mathrm{n})$ \\
\hline \multirow[t]{2}{*}{ Niobium } & ${ }^{93 \mathrm{~m}} \mathrm{Nb}$ & 16.1 & $1.0 \times 10^{-5}$ & ${ }^{93} \mathrm{Nb}\left(\mathrm{n}, \mathrm{n}^{\prime}\right)$ \\
\hline & ${ }^{94} \mathrm{Nb}$ & $2.0 \times 10^{4}$ & $7.1 \times 10^{-7}$ & $\mathrm{FP} ;{ }^{93} \mathrm{Nb}(\mathrm{n}, \gamma)$ \\
\hline Technetium & ${ }^{99} \mathrm{Tc}$ & $2.13 \times 10^{5}$ & $3.8 \times 10^{-6}$ & $\mathrm{FP} ;{ }^{99} \mathrm{Ru}(\mathrm{n}, \mathrm{p})$ \\
\hline Palladium & ${ }^{107} \mathrm{Pd}$ & $6.5 \times 10^{6}$ & $3.7 \times 10^{-5}$ & $\mathrm{FP} ;{ }^{106} \mathrm{Pd}(\mathrm{n}, \gamma)$ \\
\hline Cadmium & ${ }^{113 \mathrm{~m}} \mathrm{Cd}$ & 14.1 & ---- & FP \\
\hline \multirow[t]{2}{*}{ Tin } & ${ }^{121 \mathrm{~m}} \mathrm{Sn}$ & $\sim 55$ & $2.3 \times 10^{-6}$ & $\mathrm{FP} ;{ }^{120} \mathrm{Sn}(\mathrm{n}, \gamma)$ \\
\hline & ${ }^{126} \mathrm{Sn}$ & $2.5 \times 10^{5}$ & $2.9 \times 10^{-7}$ & $\mathrm{FP}$ \\
\hline Iodine & ${ }^{129} \mathrm{I}$ & $1.57 \times 10^{7}$ & $2.1 \times 10^{-8}$ & $\mathrm{FP} ;{ }^{129} \mathrm{Xe}(\mathrm{n}, \mathrm{p})$ \\
\hline \multirow[t]{2}{*}{ Cesium } & ${ }^{135} \mathrm{Cs}$ & $2.3 \times 10^{6}$ & $7.9 \times 10^{-7}$ & FP \\
\hline & ${ }^{137} \mathrm{Cs}$ & 30.07 & $1.2 \times 10^{-7}$ & $\mathrm{FP} ;{ }^{137} \mathrm{Ba}(\mathrm{n}, \mathrm{p})$ \\
\hline Samarium & ${ }^{151} \mathrm{Sm}$ & 90 & $1.4 \times 10^{-5}$ & $\mathrm{FP} ;{ }^{150} \mathrm{Sm}(\mathrm{n}, \gamma)$ \\
\hline \multirow[t]{3}{*}{ Europium } & ${ }^{150} \mathrm{Eu}$ & 36 & ---- & ${ }^{151} \mathrm{Eu}(\mathrm{n}, 2 \mathrm{n})$ \\
\hline & ${ }^{152} \mathrm{Eu}$ & 13.54 & $8.4 \times 10^{-7}$ & ${ }^{151} \mathrm{Eu}(\mathrm{n}, \gamma) ;{ }^{153} \mathrm{Eu}(\mathrm{n}, 2 \mathrm{n})$ \\
\hline & ${ }^{154} \mathrm{Eu}$ & 8.593 & $6.7 \times 10^{-7}$ & ${ }^{153} \mathrm{Eu}(\mathrm{n}, \gamma)$ \\
\hline Holmium & ${ }^{166} \mathrm{Ho}$ & $1.2 \times 10^{3}$ & ---- & FP; ${ }^{165} \mathrm{Ho}(\mathrm{n}, \gamma)$ \\
\hline Thorium & ${ }^{232} \mathrm{Th}$ & $1.40 \times 10^{10}$ & $9.2 \times 10^{-8}$ & natural and device component \\
\hline \multirow[t]{6}{*}{ Uranium } & ${ }^{232} \mathrm{U}$ & 69.8 & $1.0 \times 10^{-8}$ & device component; ${ }^{233} \mathrm{U}(\mathrm{n}, 2 \mathrm{n})$ \\
\hline & ${ }^{233} \mathrm{U}$ & $1.592 \times 10^{5}$ & $2.6 \times 10^{-8}$ & device component; radiochemical tracer \\
\hline & ${ }^{234} \mathrm{U}$ & $2.46 \times 10^{5}$ & $2.6 \times 10^{-8}$ & natural and device component \\
\hline & ${ }^{235} \mathrm{U}$ & $7.04 \times 10^{8}$ & $2.6 \times 10^{-8}$ & natural and device component \\
\hline & ${ }^{236} \mathrm{U}$ & $2.342 \times 10^{7}$ & $2.7 \times 10^{-8}$ & device component; ${ }^{235} \mathrm{U}(\mathrm{n}, \gamma) ;{ }^{238} \mathrm{U}(\mathrm{n}, 2 \mathrm{n})^{2}$ \\
\hline & ${ }^{238} \mathrm{U}$ & $4.47 \times 10^{9}$ & $2.6 \times 10^{-8}$ & natural and device component \\
\hline Neptunium & ${ }^{237} \mathrm{~Np}$ & $2.14 \times 10^{6}$ & $7.2 \times 10^{-9}$ & radiochemical tracer; decay of ${ }^{237} \mathrm{U}$ \\
\hline \multirow[t]{5}{*}{ Plutonium } & ${ }^{238} \mathrm{Pu}$ & 87.7 & $7.2 \times 10^{-9}$ & $\begin{array}{l}\text { device component; radiochemical tracer; } \\
{ }^{239} \mathrm{Pu}(\mathrm{n}, 2 \mathrm{n}) ;{ }^{237} \mathrm{~Np}(\mathrm{n}, \gamma)\end{array}$ \\
\hline & ${ }^{239} \mathrm{Pu}$ & $2.410 \times 10^{4}$ & $6.5 \times 10^{-8}$ & device component; decay of ${ }^{239} \mathrm{U}$ \\
\hline & ${ }^{240} \mathrm{Pu}$ & $6.56 \times 10^{3}$ & $6.5 \times 10^{-8}$ & 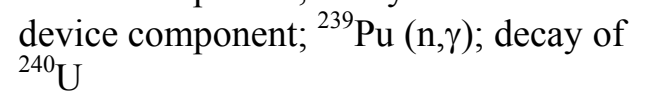 \\
\hline & ${ }^{241} \mathrm{Pu}$ & 14.4 & ---- & $\begin{array}{l}\text { device component; }{ }^{240} \mathrm{Pu}(\mathrm{n}, \gamma) \text {; decay of } \\
{ }^{241} \mathrm{U}\end{array}$ \\
\hline & ${ }^{242} \mathrm{Pu}$ & $3.75 \times 10^{5}$ & $6.8 \times 10^{-8}$ & $\begin{array}{l}\text { device component; radiochemical tracer; } \\
{ }^{241} \mathrm{Pu}(\mathrm{n}, \gamma) \text {; decay of }{ }^{242} \mathrm{U}\end{array}$ \\
\hline Americium & ${ }^{241} \mathrm{Am}$ & 432.7 & $6.4 \times 10^{-9}$ & $\begin{array}{l}\text { device component; radiochemical tracer; } \\
\text { decay of }{ }^{241} \mathrm{Pu}\end{array}$ \\
\hline & ${ }^{243} \mathrm{Am}$ & $7.37 \times 10^{3}$ & $6.5 \times 10^{-9}$ & device component; radiochemical tracer \\
\hline Curium & ${ }^{244} \mathrm{Cm}$ & 18.1 & $1.0 \times 10^{-8}$ & radiochemical tracer \\
\hline
\end{tabular}

*Half-lives obtained from GE Chart of the Nuclides, Fifteenth Edition (1996). 
half-lives less than ten years; they are ${ }^{22} \mathrm{Na},{ }^{54} \mathrm{Mn},{ }^{60} \mathrm{Co},{ }^{106} \mathrm{Ru},{ }^{125} \mathrm{Sb},{ }^{134} \mathrm{Cs}$, ${ }^{144} \mathrm{Ce}$, and ${ }^{155} \mathrm{Eu}$.

We include the above account of the different strategies studied to select radionuclides of concern at the NTS to emphasize that initial assumptions must be evaluated and care should be exercised before comparing radionuclide inventories used in previous reports. For this report, we adopt the values given in Bowen et al. (2001) as our standard.

\section{Criteria for Recommendations}

The principal goal of this report is to simplify the transport modeler's task by pointing out where in-growth is unimportant and where it needs to be considered. For the RST, assessing the importance of the decay and in-growth is relatively straightforward. Uncertainties are limited to the accuracy of the radionuclide inventory. Bowen et al. (2001) estimated uncertainties for the various groups of radionuclides in the radionuclide inventory and the table is reproduced below (Table 3). Uncertainties in the regional actinide inventories are thought to be less than $20 \%$, and will not have a significant effect on the evolution curves and the recommendations presented in this report.

Table 3. Estimated Accuracies for Individual Nuclides in the Various Groups of Radionuclides (from Bowen et al., 2001)

\begin{tabular}{|lc|}
\hline Fission products & $\sim \mathbf{1 0}$ to $\mathbf{3 0} \%$ for most of the fission \\
& products \\
\hline Unspent fuel materials: & $\sim 20 \%$ or better \\
Fuel activation products: & $\sim 50 \%$ or better \\
Residual tritium: & $\sim 300 \%$ or better \\
Activation products: & $\sim$ a factor of 10 \\
\hline
\end{tabular}

\section{Systematics of Radioactive Decay and RST Evolution}

The systematics of radioactive decay in a closed system are well known (Friedlander et al., 1981). The generalized Bateman's equation for the decay chain

$$
N_{1} \stackrel{\lambda_{1}}{\longrightarrow} N_{2} \stackrel{\lambda_{2}}{\longrightarrow} \ldots N_{i} \stackrel{\lambda_{i}}{\longrightarrow} N_{i+1} \stackrel{\lambda_{i+1}}{\longrightarrow} \ldots N_{n} \stackrel{\lambda_{n}}{\longrightarrow}
$$

where daughter initial activities are nonzero is:

$$
\begin{aligned}
N_{n}(t) & =N_{1}(0)\left\{C_{11} e^{-\lambda_{1} t}+C_{12} e^{-\lambda_{2} t} \ldots+C_{1 j} e^{-\lambda_{j} t} \ldots+C_{1 n} e^{-\lambda_{n} t}\right\} \\
& +\ldots \\
& +N_{i}(0)\left\{C_{i i} e^{-\lambda_{i} t}+C_{i(i+1)} e^{-\lambda_{i+1} t} \ldots+C_{i j} e^{-\lambda_{j} t} \ldots+C_{i n} e^{-\lambda_{n} t}\right\} \\
& +\ldots \\
& +N_{n}(0) C_{n n} e^{-\lambda_{n} t} \\
\text { where } C_{i j}= & \frac{\lambda_{i} \lambda_{i+1} \ldots \lambda_{n-1}}{\left(\lambda_{i}-\lambda_{j}\right)\left(\lambda_{i+1}-\lambda_{j}\right) \ldots\left(\lambda_{n}-\lambda_{j}\right)} \\
N= & \text { atoms,t }=\text { time } \\
\text { and } \lambda= & \ln (2) / \text { half }- \text { life }
\end{aligned}
$$


Branching decay is handled by introducing a branching fraction. For the case where $N_{i} \stackrel{f_{i}}{\longrightarrow} N_{i+1}$ and $\mathrm{f}$ is a fraction between 0 and $1, f_{i} \lambda_{i}$ replaces $\lambda_{i}$ in the numerator of all decay-constant coefficients where $\lambda_{i}$ appears, e.g.

$$
C_{i j}=\frac{f_{i} \lambda_{i} \lambda_{i+1} \ldots \lambda_{n-1}}{\left(\lambda_{i}-\lambda_{j}\right)\left(\lambda_{i+1}-\lambda_{j}\right) \cdot .\left(\lambda_{n}-\lambda_{j}\right)}
$$

In our application of Bateman's equations to radionuclide inventory nuclides and their daughters, we assumed that all daughter nuclides with half-lives of less than one year were in secular equilibrium with their parent nuclides. Secular equilibrium is a special condition that occurs for $N_{1} \stackrel{\lambda_{1}}{\longrightarrow} N_{2} \stackrel{\lambda_{2}}{\longrightarrow}$ when $\lambda_{2}>>\lambda_{1}$. After several daughter halflives $\left(\lambda_{2}\right)$, the activity of the daughter will be equal to the activity of the parent, i.e. $\lambda_{2} N_{2}=\lambda_{1} N_{1}$. Once secular equilibrium is reached, the daughter may be eliminated from the decay chain in Bateman's equations, i.e. $N_{1} \stackrel{\lambda_{1}}{\longrightarrow} N_{2} \stackrel{\lambda_{2}}{\longrightarrow} N_{3}$ becomes $N_{1} \stackrel{\lambda_{1}}{\longrightarrow} N_{3}$.

The assumption of secular equilibrium in the RST does not imply that geochemical fractionation does not occur between parent and daughter. For purposes of modeling, however, the activity of a daughter radionuclide through in-growth and decay can be assumed to be equivalent to the parent.

The final complication is nuclides with more than one parent. For example, the decay of ${ }^{238} \mathrm{U}$ (though short-lived intermediaries) and ${ }^{238} \mathrm{Pu}$ decay to ${ }^{234} \mathrm{U}$, or the decay of ${ }^{232} \mathrm{U}$ and ${ }^{228} \mathrm{Ra}$ to ${ }^{228} \mathrm{Th}$. These cases result in an additional term in the Bateman's equation, e.g.

$\ldots+N_{1 a}(0)\left\{C_{1 a 1 a} e^{-\lambda_{1 a} t}+C_{1 a 2} e^{-\lambda_{2} t} \ldots+C_{1 a j} e^{-\lambda_{j} t} \ldots+C_{1 a n} e^{-\lambda_{n} t}\right\} \ldots$

All the species in a single decay chain constitute a radioactive family or series. Many of the radionuclides in the RST have simple, fairly short decay chains. All of the radionuclides listed in the Bowen et al. (2001) inventory that have a high atomic number $(Z>80)$ have long, complex decay chains (e.g. $\left.Z_{\mathrm{Th}}=90\right)$. There are four important series that include the majority of nuclides listed in the radionuclide inventory with $Z>80$ (Figures 1-4). Figures 1-4 depict the decay relationships between the radionuclide chains for the four actinide series (from Friedlander et al. (1981)). Although not depicted in Figures 1-4, the different isotopes of $\mathrm{Pu}, \mathrm{Am}$ and $\mathrm{Cm}$ decay into these four chains and can be easily followed by using equations $9-13$. For example, ${ }^{241} \mathrm{Pu}$ decays to ${ }^{241} \mathrm{Am}$, which decays to ${ }^{237} \mathrm{~Np}$ in the neptunium series (equation 10, figure 2). Uranium-238 is the parent in the uranium series, a 14-transformation decay chain that ultimately decays to the stable nuclide, ${ }^{206} \mathrm{~Pb}$ (Figure 1). Neptunium-237 is the parent to the neptunium series that decays to the stable nuclide, ${ }^{209} \mathrm{Bi}$ (Figure 2). The $4 n+3$, or actinium series has ${ }^{235} \mathrm{U}$ as the parent and ${ }^{207} \mathrm{~Pb}$ is the stable end member (Figure 3 ). Thorium $\left({ }^{232} \mathrm{Th}\right.$ ) is the parent of the $4 \mathrm{n}$ or thorium series and it decays to the stable nuclide, ${ }^{208} \mathrm{~Pb}$ (Figure 4). 


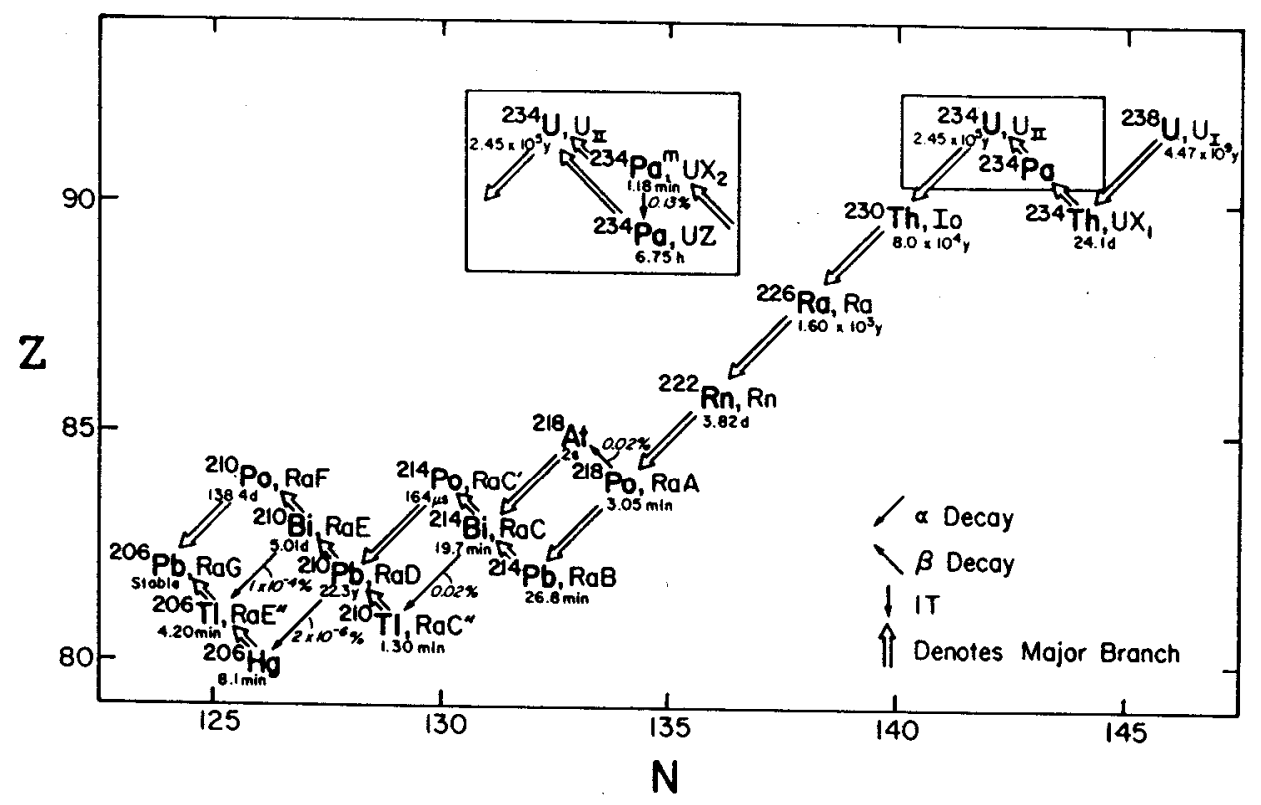

Figure 1. The uranium (U) decay series.

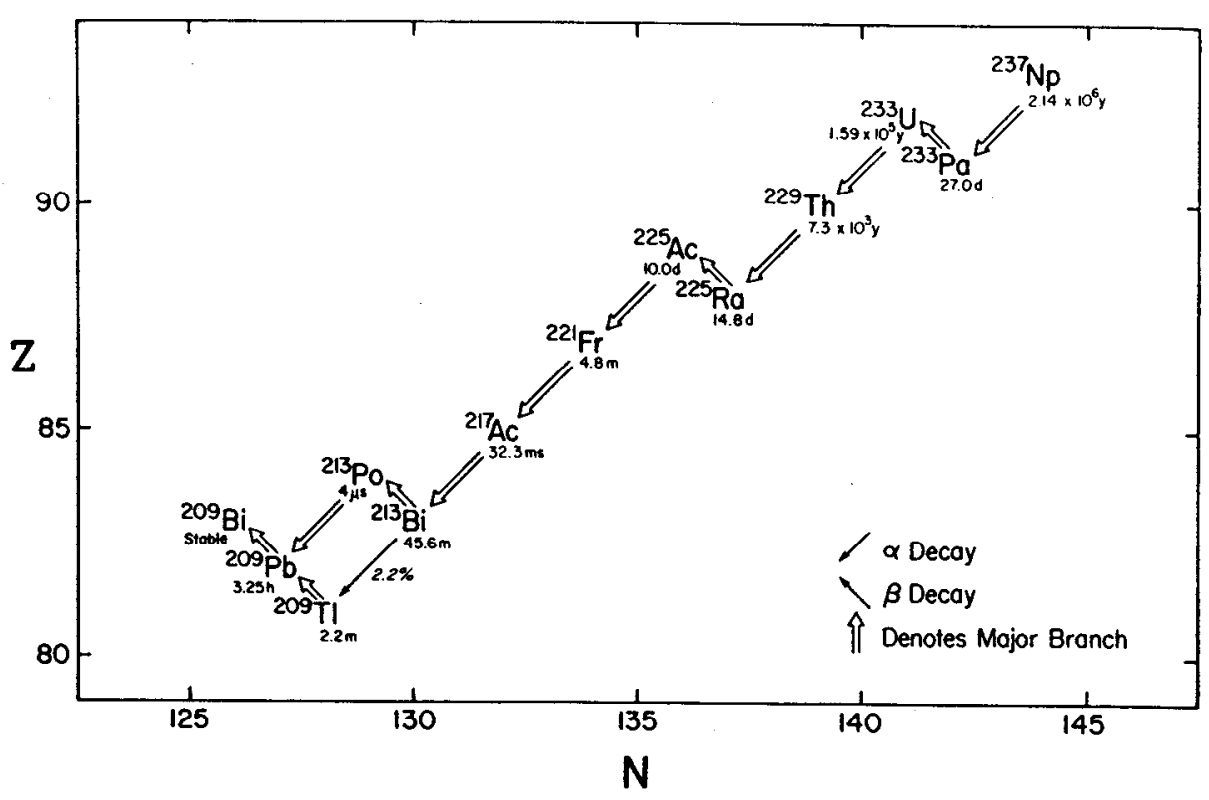

Figure 2. The neptunium ( $\mathrm{Np}$ ) decay series. 


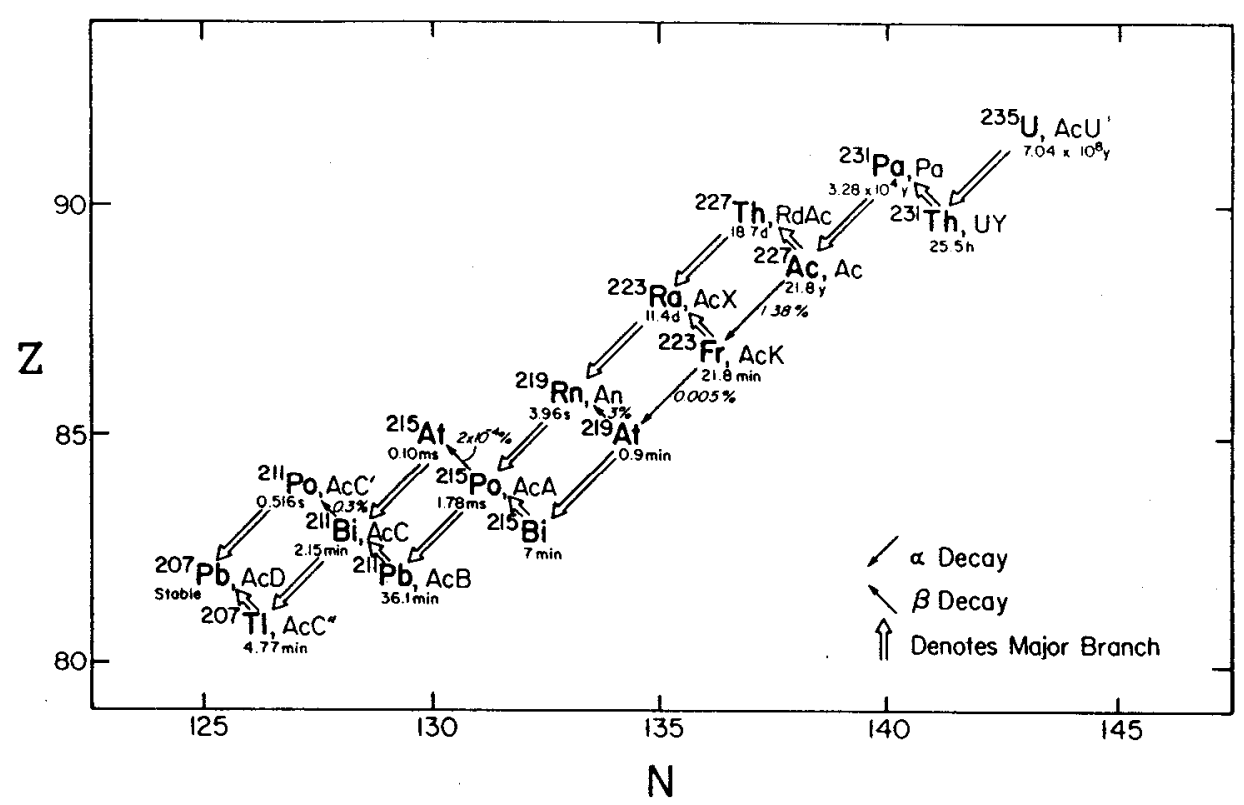

Figure 3. The actinium (Ac) decay series.

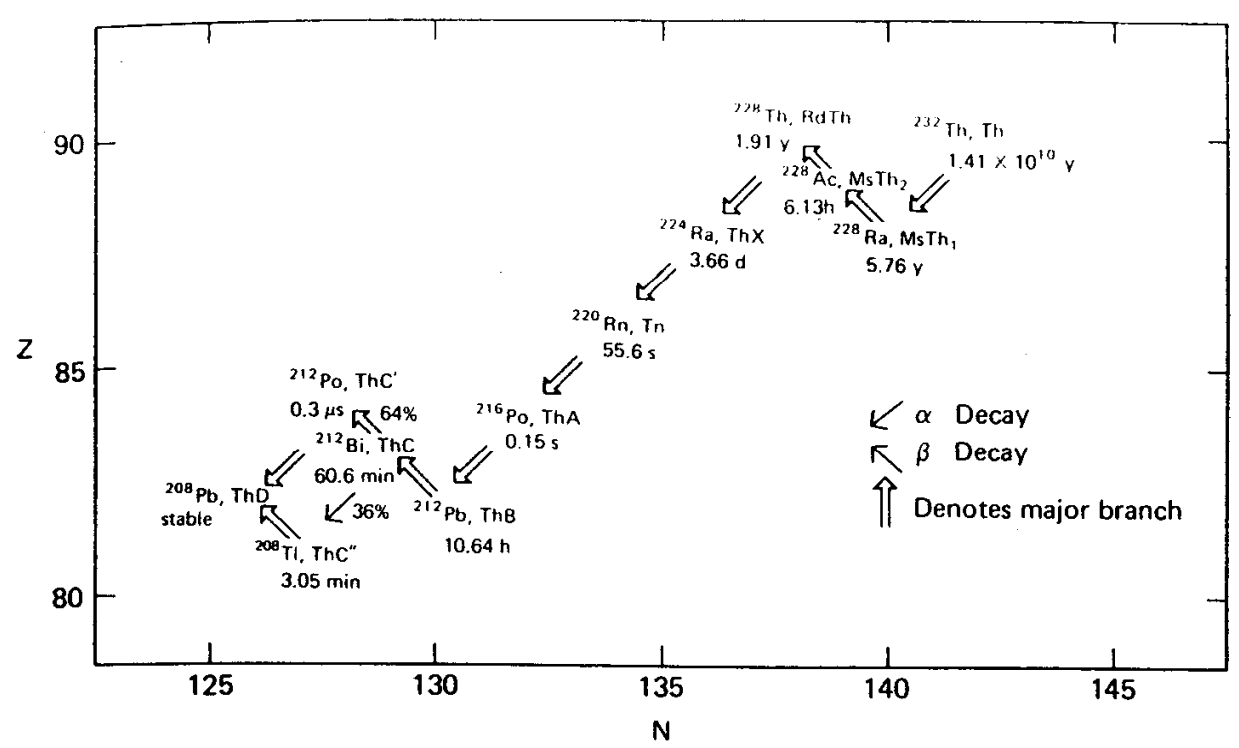

Figure 4. The thorium (Th) decay series. 


\section{Decay Chains Considered}

Microsoft Excel ${ }^{\odot}$ spreadsheets were used to model the evolution of each radionuclide in the inventory and their daughters from $0-1,000,000$ years. Bateman's equations were used with modifications as necessary to account for branching and nuclides with more than one parent. Only nuclides with half-lives of greater than one year were explicitly considered; intermediaries with half-lives of less than one year were considered to be in secular equilibrium with their parents allowing for the simplification of the equations. Time zero was September 23, 1992, and initial inventories were for the five principal geographic test centers designated in Bowen et al. (2001). The time steps were logarithmic, i.e. $0,1,2, \cdots, 10,20, \cdots, 100,200, \cdots$. A closed system was assumed, i.e. the evolution of the total radioactive inventory integrated over all phases and spatial scales was modeled.

A selection of results from modeling the evolution of each radionuclide in the inventory is shown in Figures 5 through 8. Figures 5 through 8 show the activity (Ci) for each radionuclide plotted against time for all the radionuclides that decay into the four most important and complex decay series (Figures 1-4). The figures are plotted for each of the five principal geographic test centers in the radionuclide inventory. The figures clearly show the effects of radioactive decay with time for individual radionuclides and the relative contribution of in-growth of radioactivity from parent isotopes.

\section{General Observations from the Radionuclide Inventory}

By definition, all of the 43 radionuclides selected for inclusion in the radionuclide inventory will undergo radioactive decay. After careful review of all 43 radionuclides the following observations were made:

1) All of the radionuclides in the radionuclide inventory with low to intermediate atomic numbers $(Z<80)$ will decay directly into stable, nonradioactive daughter products. They will not produce additional members of the radionuclide inventory. These 19 radionuclides from the radionuclide inventory are: ${ }^{3} \mathrm{H},{ }^{14} \mathrm{C},{ }^{26} \mathrm{Al},{ }^{36} \mathrm{Cl},{ }^{39} \mathrm{Ar},{ }^{41} \mathrm{Ca},{ }^{59} \mathrm{Ni},{ }^{63} \mathrm{Ni},{ }^{85} \mathrm{Kr},{ }^{94} \mathrm{Nb},{ }^{99} \mathrm{Tc}$, ${ }^{107} \mathrm{Pd},{ }^{113 \mathrm{~m}} \mathrm{Cd},{ }^{121 \mathrm{~m}} \mathrm{Sn},{ }^{129} \mathrm{I},{ }^{135} \mathrm{Cs},{ }^{151} \mathrm{Sm},{ }^{154} \mathrm{Eu},{ }^{166} \mathrm{Ho}$.

2) Because ${ }^{40} \mathrm{~K}$ is overwhelmingly of natural origin, it will not be considered further as a component of the RST.

3) Four members of the radionuclide inventory $\left({ }^{90} \mathrm{Sr},{ }^{126} \mathrm{Sn},{ }^{137} \mathrm{Cs},{ }^{232} \mathrm{U}\right)$ decay to short-lived radioactive daughter products with $\mathrm{t}_{1 / 2}<1$ week, which in turn, decay into stable granddaughters (see below, equations 2-5). In general, all short-lived intermediaries will exist in secular equilibrium. Therefore, their abundances can be estimated as an instantaneous function of their parent's abundance. Accordingly, inclusion of the daughters as additional members of the radionuclide inventory is not necessary. Further discussion follows in Section 5.2.

4) All of the radionuclides with high atomic number $(Z>80)$ in the radionuclide inventory are members of decay chains that include two or more members of 
the radionuclide inventory. These 19 radionuclides are members of eight additional decay chains. They are: ${ }^{93} \mathrm{Zr},{ }^{93} \mathrm{Nb},{ }^{150} \mathrm{Eu},{ }^{152} \mathrm{Eu},{ }^{232} \mathrm{Th},{ }^{233} \mathrm{U},{ }^{234} \mathrm{U}$, ${ }^{234} \mathrm{U},{ }^{236} \mathrm{U},{ }^{238} \mathrm{U},{ }^{237} \mathrm{~Np},{ }^{238} \mathrm{Pu},{ }^{239} \mathrm{Pu},{ }^{240} \mathrm{Pu},{ }^{241} \mathrm{Pu},{ }^{242} \mathrm{Pu},{ }^{241} \mathrm{Am},{ }^{243} \mathrm{Am}$, and ${ }^{244} \mathrm{Cm}$. The eight decay chains will be discussed further in Section 5.3 in terms of the relevant decay and in-growth that needs to be addressed over a 1,000 -year period.

5) There are daughters in the actinide chains (Figures 1-4), such as isotopes of radon and radium, which are regulated under Federal drinking water standards but not included in the radionuclide inventory. In all cases, the inventories are dominated by the natural component. For example, as the initial ${ }^{226} \mathrm{Ra}$ (device + natural) moves out of the cavity, it will interact with a larger volume of rock containing significant $U$ and $R a$, and the contribution of ${ }^{226} \mathrm{Ra}$ from the device component will decrease according to the inverse square law. Therefore, they do not need to be included as additional members of the radionuclide inventory.

\section{Four Radionuclides that Decay to Short-Lived Nuclides: ${ }^{90} \mathrm{Sr},{ }^{126} \mathrm{Sn},{ }^{137} \mathrm{Cs}$, and ${ }^{232} \mathrm{U}$}

The following four chains (Section 5.1, paragraph 3 above) are characterized by a parent radionuclide in the radionuclide inventory decaying into a stable, end-member daughter via one or more short-lived intermediary radionuclides.

$$
\begin{aligned}
& { }^{90} \mathrm{Sr} \stackrel{29.1 \mathrm{y} / \beta}{\longrightarrow}{ }^{90} \mathrm{Y} \stackrel{64 h / \beta}{\longrightarrow}{ }^{93} \mathrm{Zr}(\text { stable }) \\
& { }^{126} \mathrm{Sn} \stackrel{\sim 10^{6} y / \beta}{\longrightarrow}{ }^{126} \mathrm{Sb} \stackrel{{ }^{125 d / \beta}}{\longrightarrow}{ }^{126} \mathrm{Te}(\text { stable }) \\
& { }^{137} \mathrm{Cs} \stackrel{{ }^{30.1 y / \gamma} \longrightarrow}{\longrightarrow}{ }^{137 \mathrm{~m}} \mathrm{Ba} \stackrel{2.5 m / I T}{\longrightarrow}{ }^{137} \mathrm{Ba}(\text { stable }) \\
& \left.{ }^{232} \mathrm{U} \stackrel{70 y / \alpha}{\longrightarrow}{ }^{228} \mathrm{Th} \stackrel{1.9 y / \alpha}{\longrightarrow} 7 \text { short - lived intermediaries... } \longrightarrow{ }^{208} \mathrm{~Pb} \text { (stable }\right)
\end{aligned}
$$

Strontium-90, ${ }^{126} \mathrm{Sn}$ and ${ }^{137} \mathrm{Cs}$ (Equations 2-4) all have short decay chains; however, ${ }^{232} \mathrm{U}$ decays to a long, 10-member chain finally decaying to ${ }^{208} \mathrm{~Pb}$, its stable end-member daughter (Equation 5, Figure 4). ${ }^{232} \mathrm{U}$ decays to short-lived ${ }^{228} \mathrm{Th}$ that has a half-life of 1.9 years and decays via alpha-emission into several short-lived intermediaries whose halflives range from microseconds to 3.6 days. Of these, four $\left({ }^{224} \mathrm{Ra},{ }^{220} \mathrm{Rn}\right.$, ${ }^{216} \mathrm{Po}$, and $\left.{ }^{212} \mathrm{Po}\right)$ specifically decay via alpha-emission. However, because the half-lives of the ${ }^{232} \mathrm{U}$ daughters are short, we can assume they all exist in secular equilibrium with ${ }^{232} \mathrm{U}$. Therefore, their abundances can be estimated as an instantaneous function of their parent's abundance. Inclusion of the daughters as additional members of the radionuclide inventory is not necessary. 

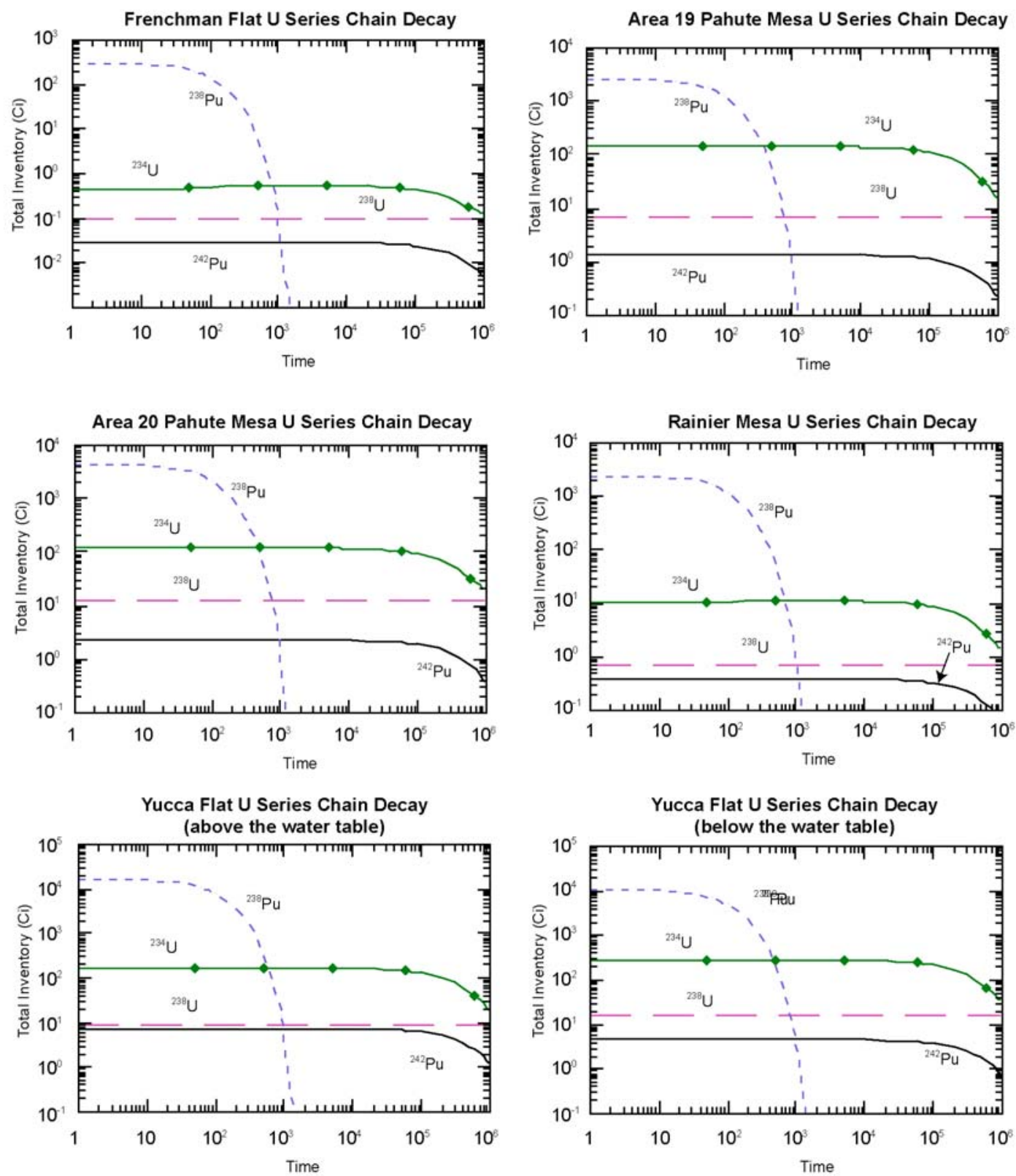

Figure 5. The activity of the each radionuclide of concern in the U-series is plotted vs. time for each of the five geographic test centers designated by Bowen et al. (2001). 
Frenchman Flat Np Series Chain Decay

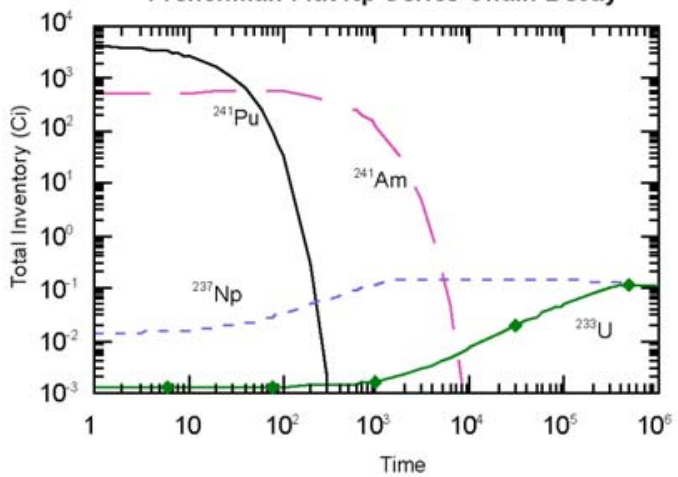

Area 20 Pahute Mesa Np Series Chain Decay

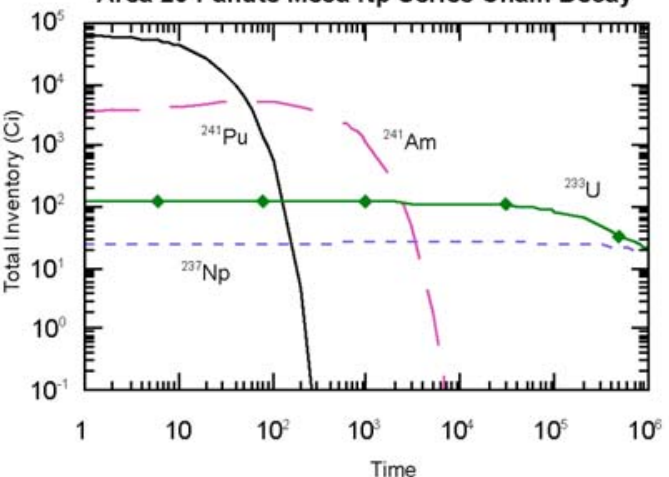

Yucca Flat Np Series Chain Decay (above the water table)

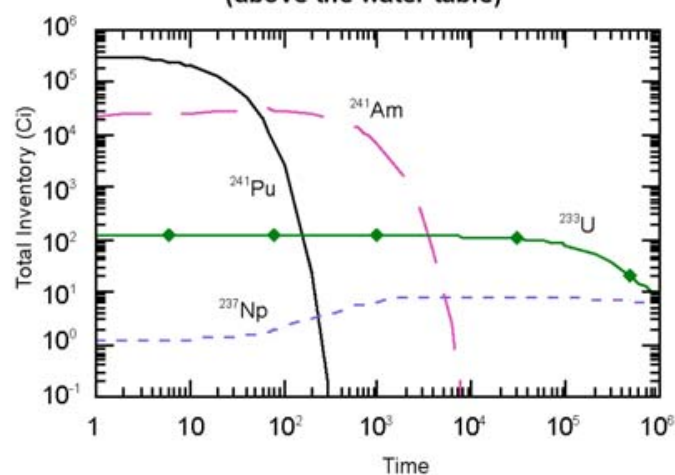

Area 19 Pahute Mesa Np Series Chain Decay

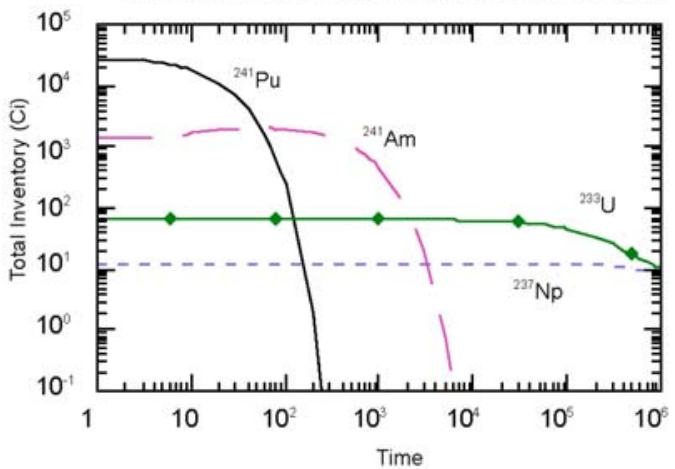

Rainier Mesa Np Series Chain Decay

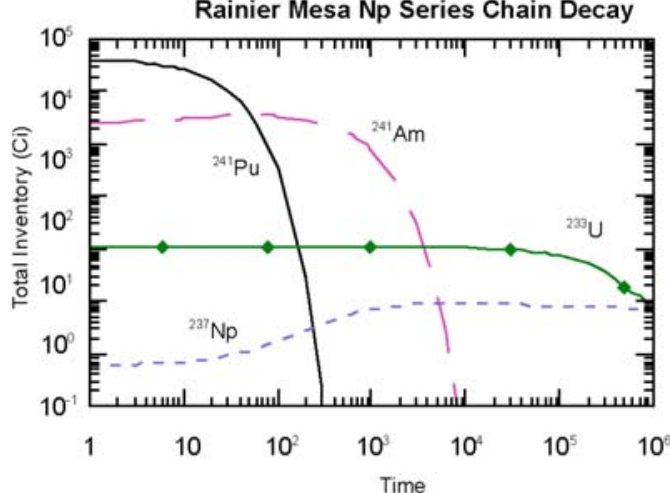

Yucca Flat Np Series Chain Decay (below the water table)

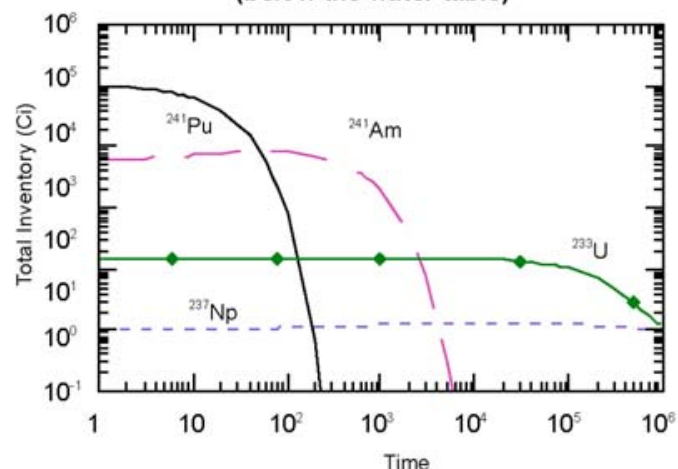

Figure 6. The activity of the each radionuclide of concern in the Np-series is plotted vs. time for each of the five geographic test centers designated by Bowen et al. (2001). 

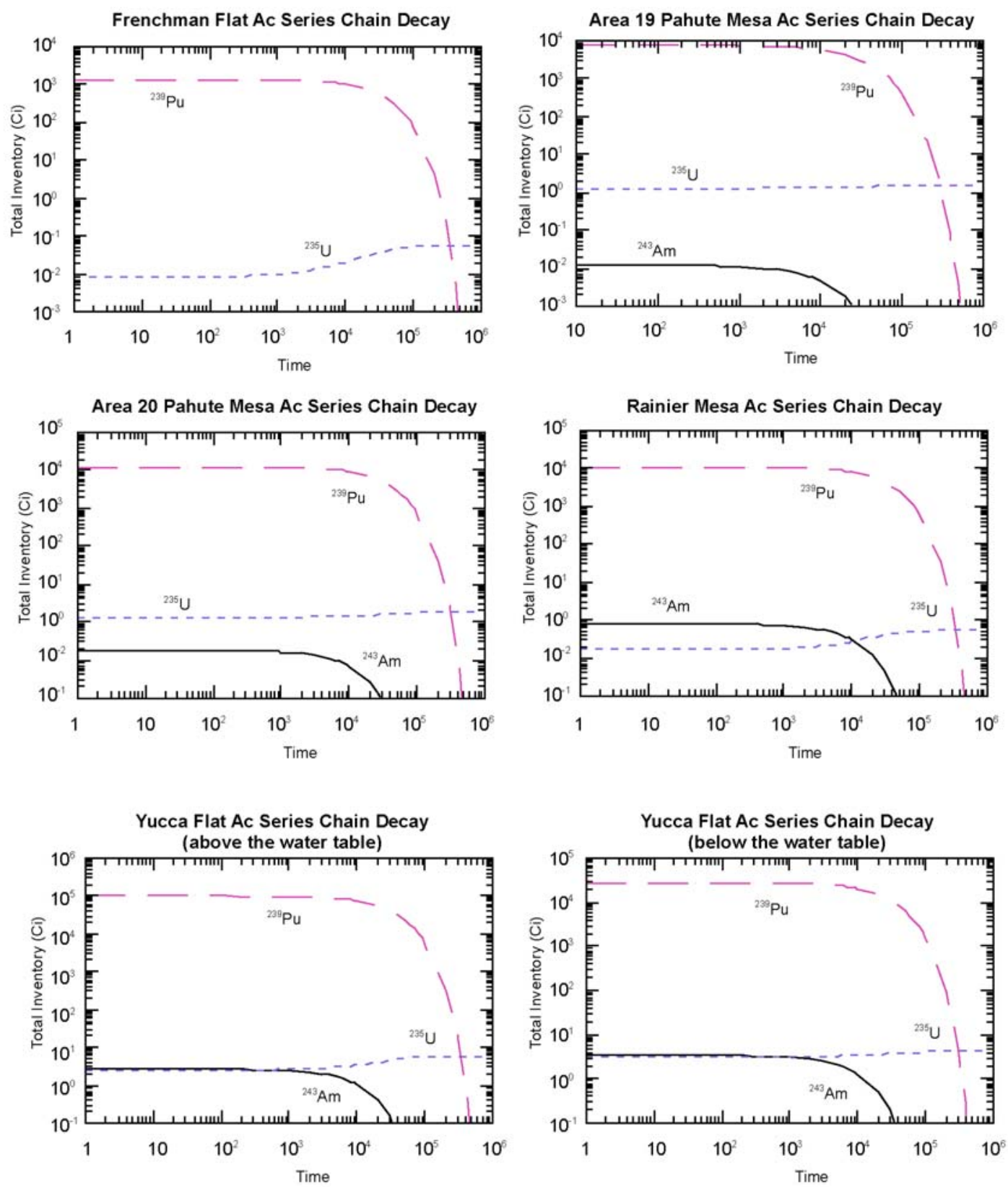

Figure 7. The activity of the each radionuclide of concern in the Ac-series is plotted vs. time for each of the five geographic test centers designated by Bowen et al. (2001). 

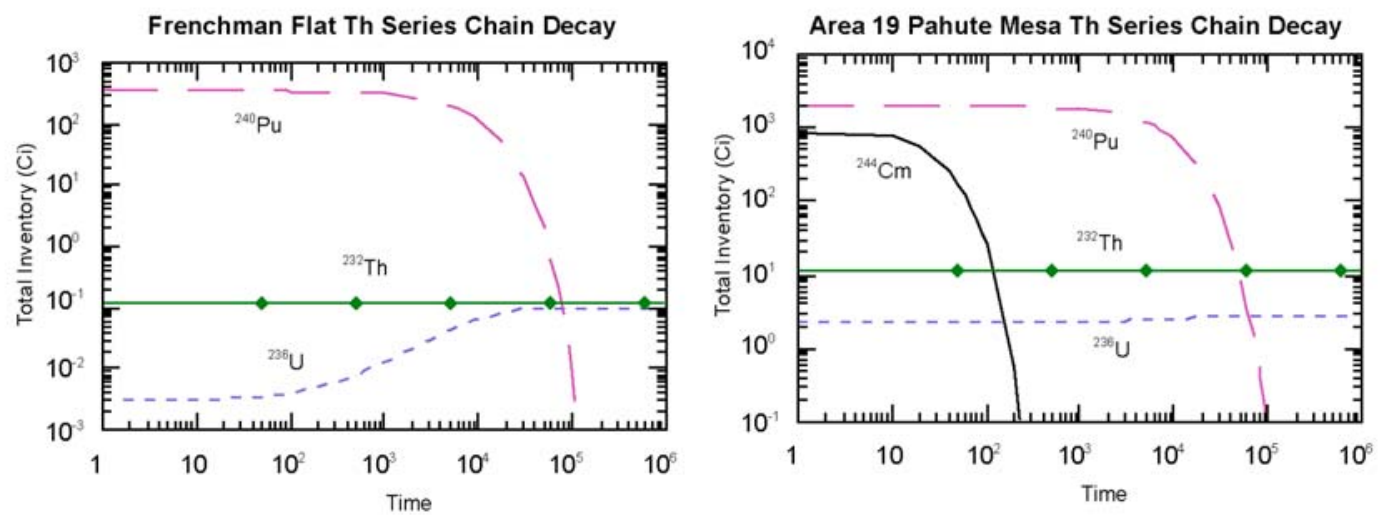

Area 20 Pahute Mesa Th Series Chain Decay

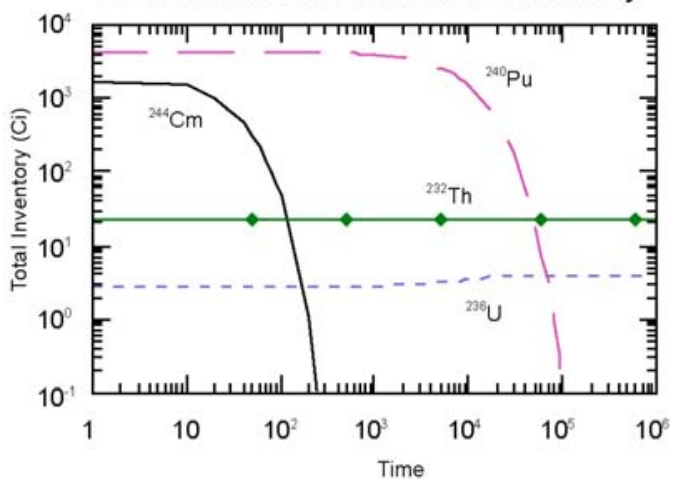

Rainier Mesa Th Series Chain Decay

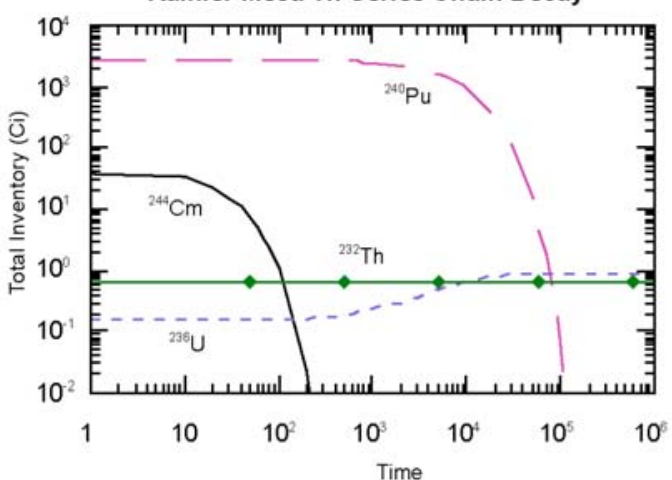

Yucca Flat Th Series Chain Decay (above the water table)
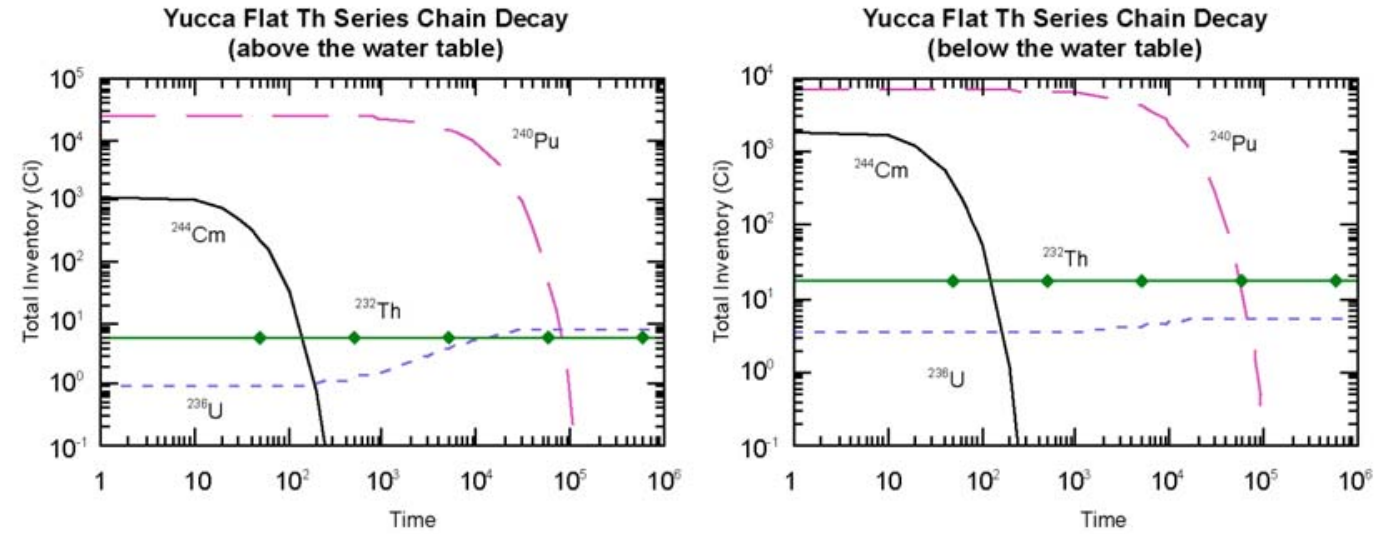

Figure 8. The activity of the each radionuclide of concern in the Th-series is plotted vs. time for each of the five geographic test centers designated by Bowen et al. (2001). 


\section{Eight Decay Chains Involving Radionuclide Inventory Nuclides}

${ }^{93} \mathrm{Zr}$ chain. Both ${ }^{93} \mathrm{Zr}$ and ${ }^{93 \mathrm{~m}} \mathrm{Nb}$ are members of the radionuclide inventory. The ingrowth of ${ }^{93 m} \mathrm{Nb}$ from ${ }^{93} \mathrm{Zr}$ over 1,000 years could be significant. Over a 1000 -year time frame the ${ }^{93 m} \mathrm{Nb}$ will be in secular equilibrium with ${ }^{93} \mathrm{Zr}$. Because of the long half-life of ${ }^{93} \mathrm{Zr}$ there will be little ${ }^{93 \mathrm{~m}} \mathrm{Nb}$ produced over the 1000 -year time frame, but because ${ }^{93} \mathrm{Zr}$ has a larger inventory than the ${ }^{93 \mathrm{~m}} \mathrm{Nb}$, there may be occasions when the in-growth from the ${ }^{93} \mathrm{Zr}$ may be significant and should be taken into account.

$$
{ }^{93} \mathrm{Zr} \stackrel{\sim 10^{6} y / \beta}{\longrightarrow}{ }^{93 m} \mathrm{Nb} \stackrel{16.1 y / I T}{\longrightarrow}{ }^{93} \mathrm{Nb} \text { (stable) }
$$

${ }^{150} \mathbf{G d}$. Gd-150, is a radionuclide that was not included in the radionuclide inventory of Bowen et al. (2001) because it is not initially produced by a nuclear test. Gd-150 is produced from the partial $(\sim 90 \%)$ decay of ${ }^{150 \mathrm{~m}} \mathrm{Eu}\left(\mathrm{t}_{1 / 2}=12.6 \mathrm{hr}\right)$. The value of ${ }^{150} \mathrm{Eu}$ in the Bowen report represents the longer-lived $70 \%$ fraction $\left(t_{1 / 2}=36 \mathrm{yr}\right)$. On the time scale of this study, the activity of ${ }^{150} \mathrm{Gd}$ will approximately equal the activity of its parent, ${ }^{150 \mathrm{~m}} \mathrm{Eu}$. Gd-150 represents an additional member of the radionuclide inventory and its in-growth should be calculated explicitly. Although the original concentration of ${ }^{150 \mathrm{~m}} \mathrm{Eu}$ was not estimated in the Bowen report (2001) because of its short half-life, it is approximately $30 \%$ of the total $\mathrm{Eu}\left({ }^{150} \mathrm{Eu}+{ }^{150 \mathrm{~m}} \mathrm{Eu}\right)$ initially produced (D.K. Smith, personal communication). Gd-150 and ${ }^{146} \mathrm{Sm}$ have such long half-lives, that on a 1,000-year time scale, the in-growth of ${ }^{146} \mathrm{Sm}$ can be effectively ignored in modeling the RST.

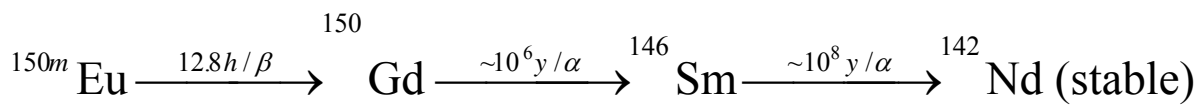

${ }^{152}$ Eu. Eu-152 decays in a $72 \%$ branch to ${ }^{152} \mathrm{Sm}$ (stable) and in a $28 \%$ branch to ${ }^{152} \mathrm{Gd}$. Eu-152 has a relatively short half-life so that over the 1000-year time frame all of the ${ }^{152} \mathrm{Eu}$ will decay. Gd-152, is a radionuclide that was not included in the radionuclide inventory of Bowen et al. (2001) because it is not initially produced by a nuclear test. On the time scale of this study, the activity of ${ }^{152} \mathrm{Gd}$ will approximately equal the activity of its parent ${ }^{152} \mathrm{Eu}$ multiplied by $4 \times 10^{-14}$ (which equals the ${ }^{152} \mathrm{Eu}$ branching ratio multiplied by the parent/daughter half-life ratio). Although the activity of ${ }^{152} \mathrm{Gd}$ can be calculated from its parent, the activity is low and is well below the $10^{-8} \mathrm{Ci} / \mathrm{mL}$ used as a criterion for inclusion in the original radionuclide inventory (Criteria 3 , page 3 this report). In addition, the half-life of ${ }^{152} \mathrm{Gd}$ is so long that it is effectively stable. Therefore, ${ }^{152} \mathrm{Gd}$ does not need to be added as an additional member of the radionuclide inventory.

Subsequent daughter products produced beyond ${ }^{152} \mathrm{Gd}$ are ${ }^{148} \mathrm{Sm}\left(\sim 10^{14} \mathrm{y}\right.$ half-life/ $\left.\alpha\right)$, ${ }^{144} \mathrm{Nd}\left(\sim 10^{15} \mathrm{y} / \alpha\right)$, and ${ }^{140} \mathrm{Ce}$ (stable). Their inventories can be estimated from the decay of ${ }^{152} \mathrm{Eu}$. Because the half-life of ${ }^{152} \mathrm{Gd}$ and ${ }^{148} \mathrm{Sm}$ are long the in-growth of ${ }^{148} \mathrm{Sm}$ can be ignored in modeling the RST.

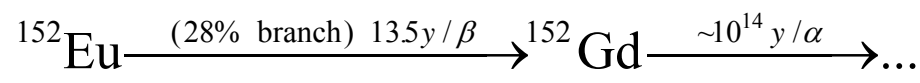


${ }^{238} \mathrm{Pu}$ chain. Both ${ }^{238} \mathrm{Pu}$ and ${ }^{234} \mathrm{U}$ are members of the radionuclide inventory and their abundance as a function of time has been modeled and plotted in Figure 5. Pu-238 decays with a relatively short half-life into ${ }^{234} \mathrm{U}$. The decay of ${ }^{238} \mathrm{Pu}$, and ${ }^{238} \mathrm{U}$ (from natural abundances and nuclear weapons) both contribute to the in-growth of ${ }^{234} U$ (Equation 9, Figure 1). The concentration of ${ }^{234} \mathrm{U}$ should be treated explicitly. The in-growth of any short-lived daughters from the parent, ${ }^{234} \mathrm{U}$, can be ignored because the contribution from natural $\mathrm{U}$ overwhelms the $\mathrm{U}$ contribution that comes from underground nuclear testing.

There are isotopes such as radon and radium that are of concern in the environment but the natural inventory from the decay of $\mathrm{U}$ overwhelms the contribution from underground nuclear testing (Figures 1-4). For example, as the initial ${ }^{226} \mathrm{Ra}$ (device + natural) moves out of the cavity, it will interact with a larger volume of rock containing significant $U$ and $\mathrm{Ra}$, and the contribution from device component to the total ${ }^{226} \mathrm{Ra}$ inventory will decrease according to the inverse square law. Therefore, radon and radium do not need to be included as additional members of the radionuclide inventory.

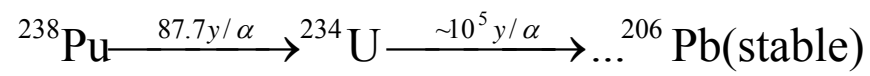

${ }^{241}$ Pu chain. Four of the first five members of decay chain (Equation 10) are included as members of the radionuclide inventory and their abundance as a function of time has been modeled and plotted in Figure 6. The coupled decay and in-growth between ${ }^{241} \mathrm{Pu}$, ${ }^{241} \mathrm{Am}$, and ${ }^{237} \mathrm{~Np}$ must be treated explicitly in a transport model because of their relatively short half-lives. The ${ }^{241} \mathrm{Pu}\left(\mathrm{t}_{1 / 2}=14.4 \mathrm{y}\right)$ will significantly increase the activity of the ${ }^{241} \mathrm{Am}$ and consequently the ${ }^{237} \mathrm{~Np}$ on the 1000 -year time scale. The in-growth of ${ }^{241} \mathrm{Am}$ can be observed by the slight increase in ${ }^{241} \mathrm{Am}$ curve at less than 100 years (Figure 6). Since the half-lives of ${ }^{237} \mathrm{~Np}$ and ${ }^{233} \mathrm{U}$ are long, the in-growth of ${ }^{233} \mathrm{U}$ and subsequent daughters can be effectively excluded in our 1,000-year decay and transport calculations.

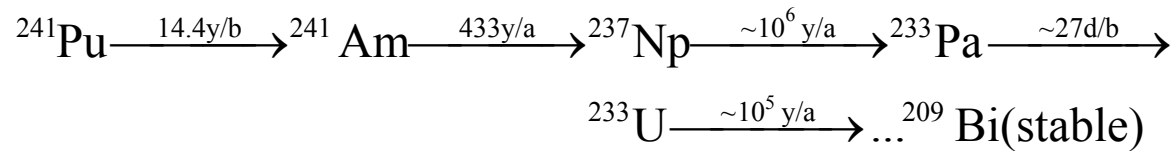

${ }^{242} \mathrm{Pu}$ chain. Three members $\left({ }^{242} \mathrm{Pu},{ }^{238} \mathrm{U},{ }^{234} \mathrm{U}\right.$ ) in this decay chain (Equation 11) are members of the radionuclide inventory and their abundance as a function of time has been modeled and plotted in Figure 5. Because of the long half-life of ${ }^{242} \mathrm{Pu}$ and the high initial concentration of ${ }^{238} \mathrm{U}$ in the RST the in-growth of ${ }^{238} \mathrm{U}$ from ${ }^{242} \mathrm{Pu}$ is not of concern in our 1,000-year time frame. The concentration of ${ }^{234} \mathrm{U}$ should be treated explicitly because of both the in-growth from $\mathrm{Pu}-238$ (see above) and ${ }^{238} \mathrm{U}$ (from natural abundances and nuclear weapons). The in-growth of any short-lived daughters from the parent, ${ }^{234} \mathrm{U}$, can be ignored because the contribution from natural $\mathrm{U}$ overwhelms the $\mathrm{U}$ contribution that comes from underground nuclear testing.

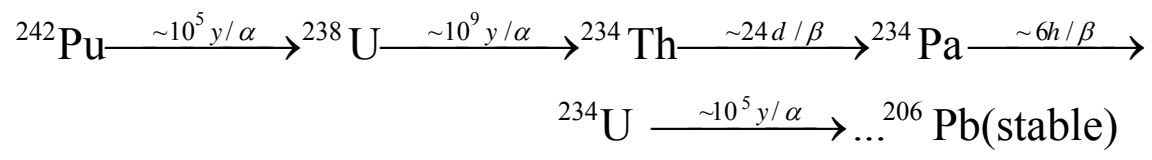


${ }^{243}$ Am chain. Three members in this decay chain (Equation 12) are members of the radionuclide inventory and their abundance as a function of time has been modeled and plotted in Figure 7. The combination of a relatively long half-life for ${ }^{243} \mathrm{Am}$ and a relatively small original source term compared to that of ${ }^{239} \mathrm{Pu}$ makes the in-growth of ${ }^{239} \mathrm{Pu}$ unimportant. Plutonium-239 has a long half-life relative to the 1000 -year time period evaluated for this report so in-growth of ${ }^{235} \mathrm{U}$ from ${ }^{239} \mathrm{Pu}$ is probably not important. In-growth would be important for time frames just greater than 1000 years, especially for areas where the original source term for ${ }^{235} \mathrm{U}$ is much lower than ${ }^{239} \mathrm{Pu}$. Figure 7 shows the effects of in-growth of ${ }^{235} \mathrm{U}$ becoming important just after 1000 years. Uranium-235 has a long half-life and further decay into additional daughters can be ignored in 1,000year decay and transport calculations.

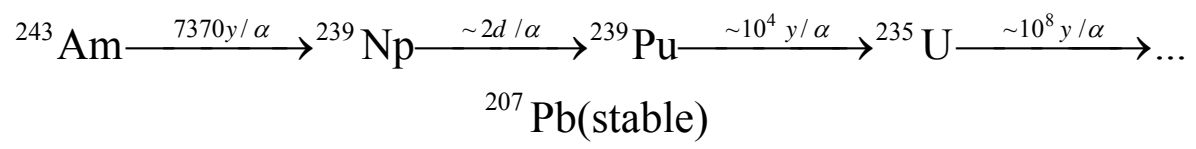

${ }^{244} \mathrm{Cm}$ chain. Each of the first four members in this decay chain (Equation 13) is a member of the radionuclide inventory and their abundance as a function of time has been modeled and plotted in Figure $8 . \mathrm{Cm}-244$ has a short half-life and it will all decay to ${ }^{240} \mathrm{Pu}$ in the 1000 -year time frame. The in-growth of ${ }^{240} \mathrm{Pu}$ should be treated explicitly although the contribution may be insignificant where the ${ }^{240} \mathrm{Pu}$ source term is much larger than ${ }^{244} \mathrm{Cm}$. The in-growth of ${ }^{236} \mathrm{U}$ from ${ }^{240} \mathrm{Pu}$ must be treated explicitly as well. The long half-life of ${ }^{236} \mathrm{U}$ and the large initial concentrations of ${ }^{232} \mathrm{Th}$ in the RST suggest that the in-growth of ${ }^{232} \mathrm{Th}$ from ${ }^{236} \mathrm{U}$, and subsequent daughters will not be significant over the $1,000-$ year decay period.

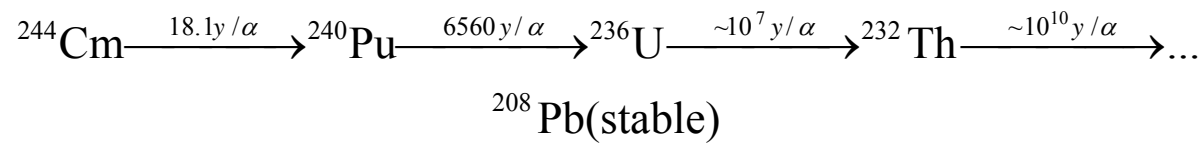

\section{Summary}

The relevant decay and in-growth of radionuclides from the radiologic inventory compiled by Bowen et al. (2001) were evaluated over the 1000-year time frame in order to determine whether coupled in-growth and decay affect the relative abundance of any RST radionuclide. The radionuclide inventory data in Bowen et al. (2001) was the basis for our assessment as individual radionuclide inventory data for specific nuclear tests are classified.

All of the radionuclides in the radionuclide inventory with low to intermediate atomic numbers $(Z<80)$ will decay directly into stable, nonradioactive daughter products. They will not produce additional members of the radionuclide inventory.

The short-lived radionuclides in decay chains with long-lived parents will exist in secular equilibrium with their parents and their abundances can be estimated from the abundance of their parent. Some examples of this are ${ }^{90} \mathrm{Sr}$ and ${ }^{90} \mathrm{Y},{ }^{137} \mathrm{Cs}$ and ${ }^{137 m} \mathrm{Ba}$, and ${ }^{232} \mathrm{U}$ and ${ }^{228} \mathrm{Th}$. Inclusion of the daughters as additional members of the radionuclide inventory is not necessary. 
There are daughters in the actinide chains, such as isotopes of radium and radon that are of concern in the environment, but the background from the decay of natural uranium dwarfs the contributions from the RST. Therefore, they do not need to be included as additional members of the radionuclide inventory.

There are eight decay chains that involve long decay and in-growth patterns that have been discussed in this report. The following is a summary of only the radionuclides where in-growth should be calculated explicitly.

- ${ }^{93} \mathrm{Zr} \rightarrow{ }^{93 m} \mathrm{Nb} \rightarrow{ }^{93} \mathrm{Nb}$ : The in-growth of ${ }^{93 m} \mathrm{Nb}$ from ${ }^{93} \mathrm{Zr}$ over 1,000 years could be significant. Over a 1000 year time frame the ${ }^{93 m} \mathrm{Nb}$ will be in secular equilibrium with ${ }^{93} \mathrm{Zr}$. Since the ${ }^{93} \mathrm{Zr}$ has a much higher initial concentration in the RST, it is possible that the in-growth of ${ }^{93 \mathrm{~m}} \mathrm{Nb}$ could be significant.

- ${ }^{150} \mathrm{Gd}$ : Gd-150, is an additional member of the radionuclide inventory that was not included in the radionuclide inventory of Bowen et al. (2001) because it is not initially produced by a nuclear test. The in-growth of ${ }^{150} \mathrm{Gd}$ should be calculated explicitly. Gd-150 is produced from the partial decay of ${ }^{150 \mathrm{~m}} \mathrm{Eu}\left(\mathrm{t}_{1 / 2}=12.6 \mathrm{hr}\right)$. Although the original concentration of ${ }^{150 \mathrm{~m}} \mathrm{Eu}$ was not estimated in the Bowen report (2001) because of its short half-life, it is approximately $30 \%$ of the total $\mathrm{Eu}\left({ }^{150} \mathrm{Eu}+{ }^{150 \mathrm{~m}} \mathrm{Eu}\right)$ produced (D.K. Smith, personal communication).

- $\quad{ }^{238} \mathrm{Pu} \rightarrow{ }^{234} \mathrm{U}$ : The ${ }^{238} \mathrm{Pu}$ will decay to ${ }^{234} \mathrm{U}$ over the 1000 -year time frame considered. The in-growth of ${ }^{234} \mathrm{U}$ from ${ }^{238} \mathrm{Pu}$, natural ${ }^{238} \mathrm{U}$ and weapons related ${ }^{238} \mathrm{U}$ should be treated explicitly. This may be of consequence in tests with a small ${ }^{234} \mathrm{U}$ source term.

- $\quad{ }^{241} \mathrm{Pu} \rightarrow{ }^{241} \mathrm{Am} \rightarrow{ }^{237} \mathrm{~Np}$ : This is probably the most important decay and in-growth chain in the RST. In-growth is important for calculating both ${ }^{241} \mathrm{Am}$ and ${ }^{237} \mathrm{~Np}$.

- ${ }^{243} \mathrm{Am} \rightarrow{ }^{239} \mathrm{~Np} \rightarrow{ }^{239} \mathrm{Pu} \rightarrow{ }^{235} \mathrm{U}$ : Although ${ }^{239} \mathrm{Pu}$ has a long half-life relative to the 1000 -year time period evaluated, it has a large source term compared to ${ }^{235} \mathrm{U}$. In-growth of ${ }^{235} \mathrm{U}$ should be treated explicitly as it becomes significant just after the 1000-year time frame (Figure 7).

- $\quad{ }^{244} \mathrm{Cm} \rightarrow{ }^{240} \mathrm{Pu} \rightarrow{ }^{236} \mathrm{U} \rightarrow{ }^{232} \mathrm{Th}$ : The in-growth of ${ }^{240} \mathrm{Pu}$ should be treated explicitly although the contribution may be insignificant where the ${ }^{240} \mathrm{Pu}$ source term is much larger than ${ }^{244} \mathrm{Cm}$. The in-growth of ${ }^{236} \mathrm{U}$ from ${ }^{240} \mathrm{Pu}$ must be treated explicitly.

It should be emphasized again that conclusions drawn from this document are based on the 1000-year time frame and the same conclusions need not hold for either shorter or longer time periods. As shown in Figures 5 through 8, the radionuclide inventory for each nuclide in a decay series will vary with the time period of interest. 


\section{Acknowledgments}

Underground Test Area, NNSA/NSO, funded the work. Work performed under the auspices of the U. S. Department of Energy by the University of California, Lawrence Livermore National Laboratory under contract W-7405-ENG-48.

\section{References}

Bowen S. M., Finnegan D. L., Thompson J. L., Miller C. M., Baca P. L., Olivas L. F., Geoffrion C. G., Smith D. K., Goishi W., Esser B. K., Meadows J. W., Namboodiri N., and Wild J. F. (2001) Nevada Test Site radionuclide inventory, 1951-1992. Los Alamos National Laboratory Internal Report. LA-13859-MS pp. 28.

Esser B. K. (1994) Chain Decay of the UGTA Total Radionuclide Source Term. Lawrence Livermore National Laboratory Internal Report. UCRL-MI-153498 pp. 21.

Friedlander G., Kennedy J. W., and Macias E. S. (1981) Nuclear and Radiochemistry. John Wiley $\&$ Sons.

General Electric Company. (1996) Chart of the nuclides, 15th edition. General Electric Company, Nuclear Energy Operations.

Goishi W., Esser B. K., Meadows J. W., Namboodiri N., Smith D. K., Wild J. F., Bowen S. M., Baca P. L., Olivas L. F., Geoffrion C. G., Thompson J. L., and Miller C. M. (1994) Total radionuclide inventory associated with underground nuclear tests conducted at the Nevada Test Site, 1955-1992 (U). Los Alamos National Laboratory Internal Report. LA-CP-940222 .

Miller C. M., Bowen S. M., Finnegan D. L., Thompson J. L., Baca P. L., Olivas L. F., Geoffrion C. G., Smith D. K., Goishi W., Esser B. K., Meadows J. W., Namboodiri N., and Wild J. F. (2001) Total radionuclide inventory associated with underground nuclear tests conducted at the Nevada Test Site, 1951-1992 (U). Los Alamos National Laboratory Internal Report. LA-13989.

Pawloski G. A., Tompson A. F. B., and Carle S. F. E. (2001.) Appendix A in: Evaluation of the hydrologic source term from underground nuclear tests on Pahute Mesa at the Nevada Test Site; The CHESHIRE test. Lawrence Livermore National Laboratory Internal Report. UCRL-ID-147023 pp. A1-A19.

Smith D. K. (2001) Unclassified radiologic source term for Nevada Test Site Areas 19 and 20. Lawrence Livermore National Laboratory Internal Report. UCRL-ID-141706 pp. 4.

Tompson A. F. B., Zavarin M., Bruton C. J., and Pawloski G. A. (in review) Simplified hydrologic source term for Frenchman Flat sensitivity studies. Lawrence Livermore National Laboratory Internal Report. pp. 59.

U.S. Environmental Protection Agency. (1991) 40 CFR Parts 141 and 142; National Primary Drinking Water Regulations; Radionuclides; Proposed Rule. Federal Register(56), 3305033127.

Worgan K. J. and Apted M. J. (1992) The effect of precipitation fronts induced by radionuclide chain decay and elemental solubility limits. Mat. Res. Soc. Symp. Proc. 257(705-712). 


\title{
Chapter 4
}

\section{Results of Transmission Electron Microscopy Analysis of Individual Groundwater Colloid Samples from the Nevada Test Site}

\author{
Annie Kersting
}

\section{Introduction}

Understanding the transport behavior of the light actinides ( $\mathrm{U}, \mathrm{Np}, \mathrm{Pu}, \mathrm{Am})$ in the subsurface is an important scientific problem for both the Underground Test Area (UGTA) program and the DOE complex. It has recently been demonstrated that Pu and Am are not immobile in the subsurface as once believed, but low levels of these actinides can be transported in both groundwater and surface water. A new paradigm has emerged that focuses on colloid-facilitated transport as the dominant mechanism for transporting low-solubility radionuclides. Colloids are defined as $<1$ micron particulates and due to their small size have the ability to remain suspended and transported in water. Actinide colloids can consist of actinides adsorb to inorganic or organic substrates (pseudocolloids) or can form their own colloids (intrinsic colloids). Although colloid-facilitated transport of actinides has been suggested, a major scientific challenge remains to identify the nature (both chemical form and oxidation state) of actinides in different environmental settings.

For plutonium $(\mathrm{Pu})$ it is currently hypothesized that the low-solubility actinides, such as $\mathrm{Pu}$ are transported as either colloidal oxy-hydroxide $\left(\mathrm{PuO}_{2} \bullet \mathrm{nH}_{2} \mathrm{O}\right)$ or adsorbed to naturally occurring organic or inorganic colloids. There is currently no means to test this hypothesis, as the fundamental nature of the actinide-colloid interface in nature is unknown. There is also no method by which the distribution of specific actinides within a population of colloidal particles can be determined. One of the reasons that this question remains unresolved is that actinide concentrations on environmental samples are extremely low, and the ability to identify single actinide nanoparticles using current spectroscopic technology has not previously been possible. As a result, transport modeling efforts must take into account the sorption/desorption kinetics of $\mathrm{Pu}$ on all common minerals available for transport as well as the thermodynamic behavior of intrinsic $\mathrm{Pu}$. This is a huge undertaking and could be immensely simplified if knowledge as to the $\mathrm{Pu}$-colloid interface was known. For example, if $\mathrm{Pu}$ was only detected as a colloidal oxy-hydroxide, modeling Pu transport would be much simplified, as knowledge of the sorption/desorption kinetics of $\mathrm{Pu}$ to all common silicates would be unnecessary.

\section{Goals and Objectives}

Therefore, the primary goal of this work was to take advantage of a newly developed technology pioneered at the University of Michigan (PI Lumin Wang), designed to scan large numbers of individual nanoparticles prior to analysis using the high-resolution 
transmission electron microscope (HRTEM). The technology of atomic-contrast imaging with high angle annular dark field (HAADF) in scanning transmission electron microscopy (STEM) mode can be used to detect and identify nanoparticles of high local atomic mass $(Z)$ (e.g. actinides) at very low natural abundances in groundwater colloids. The conventional TEM can identify the crystalline structure and chemical composition of nanoparticles, but its main limitation is that it cannot scan large numbers of particles. Looking for low-levels of actinides with a conventional TEM becomes a 'needle in a haystack problem'. We wanted to use the HAADF in STEM mode to identify Pu and determine whether it exists as a colloidal oxy-hydroxide $\left(\mathrm{PuO}_{2} \bullet \mathrm{nH}_{2} \mathrm{O}\right)$ or adsorbed to naturally occurring organic or inorganic colloids. In addition, we hoped to use the TEM to definitively identify the composition of colloids previously identified using x-ray diffraction (XRD).

Although some preliminary results were first included in Hydrologic Resources Management Program and Underground Test Area Project FY2000 Progress Report (UCRL-ID-145167), they have been re-summarized here for completeness.

\section{Results}

Extensive TEM analysis was conducted on colloids separated from groundwater samples collected from wells ER20-5-1, ER20-5-3, and vadose zone water collected from U12Tunnel complex at the NTS. Bright-field (BF), dark-field (DF) and high resolution (HR) TEM imaging, selected area electron diffraction (SAD) as well as nano-beam energy dispersive $\mathrm{x}$-ray spectroscopy (EDS) analyses were conducted for the characterization of these samples. A $200 \mathrm{keV}$ electron beam was used for the analysis. In order to create electron transparent thin areas for the analysis, the original colloid clusters in the sample were crushed and suspended on holey-carbon films supported by copper grids, so the original morphology observed in the SEM analysis may have been altered. However, it is unlikely that the nanometer scaled colloids themselves were crushed and changed in morphology. Although extensive effort was devoted to the analyses, only a small fraction $(\sim 10 \%)$ of the colloids collected on the grids was ultimately analyzed. Due to secondary electron and/or fluorescent x-ray excitation, the copper signal from the supporting grids could not be avoided even with a well focused electron beam (typically, a beam diameter of $2 \mathrm{~nm}$ has been obtained) during EDS analysis.

The following mineral colloids were identified:

- All groundwater samples contained clays. The dimensions of these phases range from several nanometers to several hundreds of nanometers. The local composition of these phases may vary a lot which is not surprising given the complex solid solution and cation substitution commonly found in the clay mineral groups. Smectite was identified. Illite was identified by direct observation of the $2 \mathrm{~nm}$ spacing of the (001) basal planes. (Fig 1A \&B).

- The tunnel sample contained calcite colloids, 100-200 nm in size (Fig. 1C.). Calcite was not identified in the other groundwater samples.

- All groundwater samples contained zeolites (Fig. 1D). The presences of the zeolite, clinoptilolite, was confirmed. 
- Small silica grains (10 to $200 \mathrm{~nm}$ in dimensions) were also found in all samples and were further identified as tridymite according to the diffraction pattern and dspacing measured from HREM images.

- Ru-rich colloid was detected, but remains unidentified (Fig. 1E). An unidentified phase containing $\mathrm{Th}$ and $\mathrm{Ce}$ and an amorphous sulfur-rich phase were documented.

- Gold nano-particles were identified in the tunnel samples (Fig. 1F). The Au nanoparticles ranged between $2-10 \mathrm{~nm}$ and were found in the vicinity of the Rurich phases.

Most of the analysis has been focused on finding the heavy elements such as $\mathrm{Pu}, \mathrm{Am}$, etc. We probed hundreds of spots in each specimen using the focused electron beam for EDS analysis. High atomic number elements were detected associated with $\mathrm{Ca}, \mathrm{Al}$ silicates are shown in Figure 2. Silicate colloids containing U, Au, Ag, Zr, Ba, Ce, Fe were observed. These particles have a diameter range between 10-100 $\mathrm{nm}$ and are absorbed on the surface of the (Ca, K, Si, Al, S, Na)-rich silicate phases. Unfortunately, the only actinide detected was $\mathrm{U}$. No $\mathrm{Pu}$ was detected on the samples investigated.

\section{Summary}

We have successfully used HAAD in scanning TEM mode to detect and identify nanoparticles of high local mass $(Z)$ at very low natural abundances in groundwater colloids. Combined with energy dispersive x-ray spectroscopy (EDS), we were able to detect nanoscale radionuclide colloids sorbed onto silicate colloids in groundwater downgradient of underground nuclear tests at the Nevada Test Site (NTS).

Furthermore, high resolution TEM, nanobeam electron diffraction and EDS have also been used for the identification of the mineral colloids and the sorbed nanoparticles. Mineral phases such as smectite, illite, clinoptilolite, calcite, monazite, rutile, tridymite, as well as thorium phosphate were identified in the samples analyzed to date.

Although the HAAD-STEM technique worked very well for locating and identifying nanoparticles at the very small spatial scales required, we were ultimately still only looking at a very small percentage of the sample available. For determining the actinidecolloid interface on samples with actinide concentrations at environmental levels we may need to wait until we can develop technology that combines a very high particle throughput with nanoscale chemical detection. 

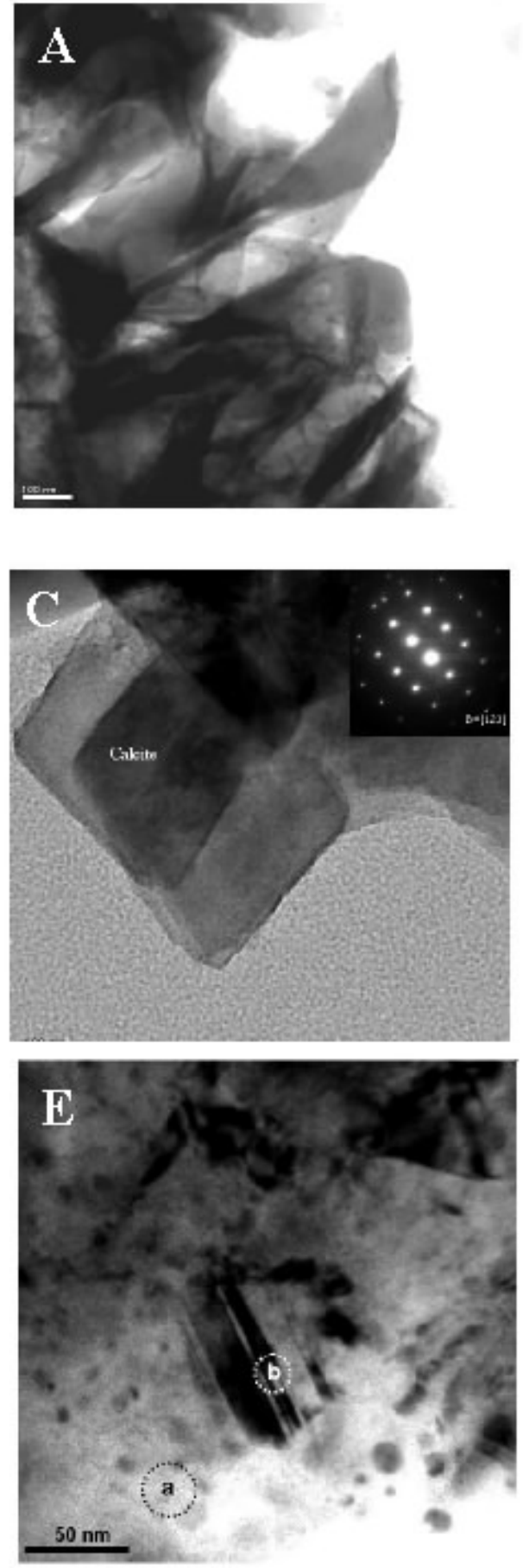
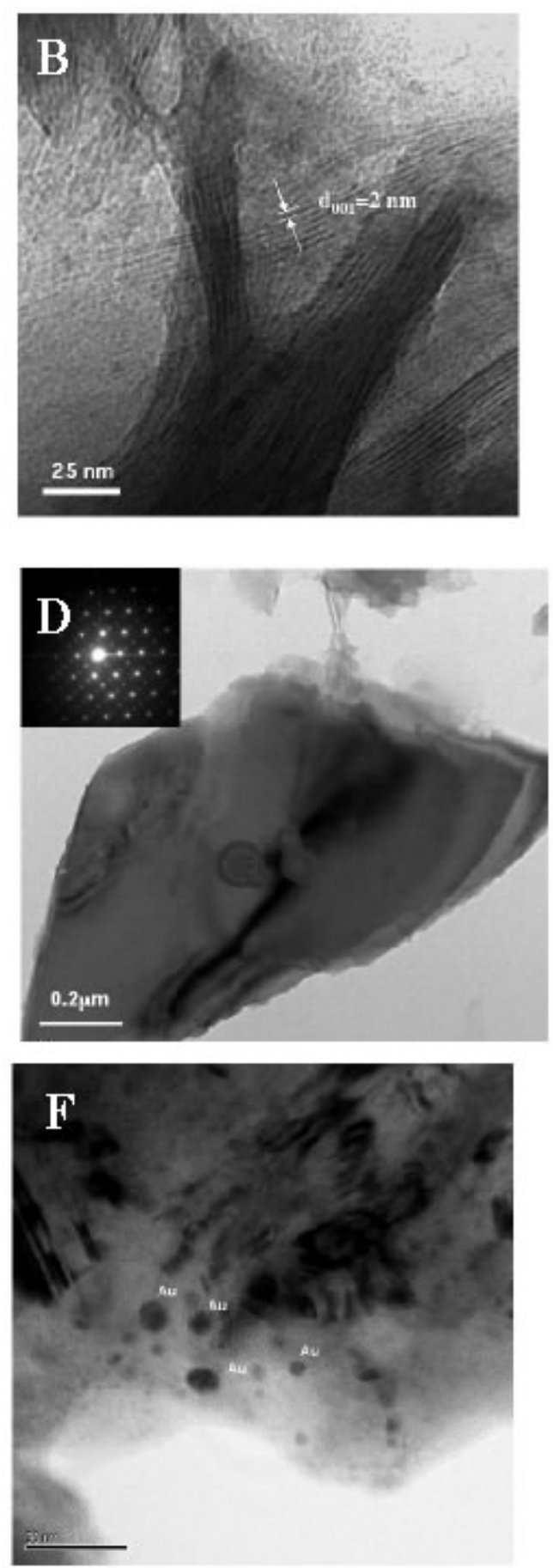

Figure 1. TEM images. A: Bright field TEM image of illite. B: High-resolution TEM image of illite grains showing basal spacing. C: Bright field TEM image of calcite with diffraction pattern in upper right. D: Bright field TEM image of zeolite, clinoptilolite with diffraction pattern in upper left. E: Bright field TEM image of Ru-rich colloid. F: Bright-field TEM image with Au nanoparticles. 


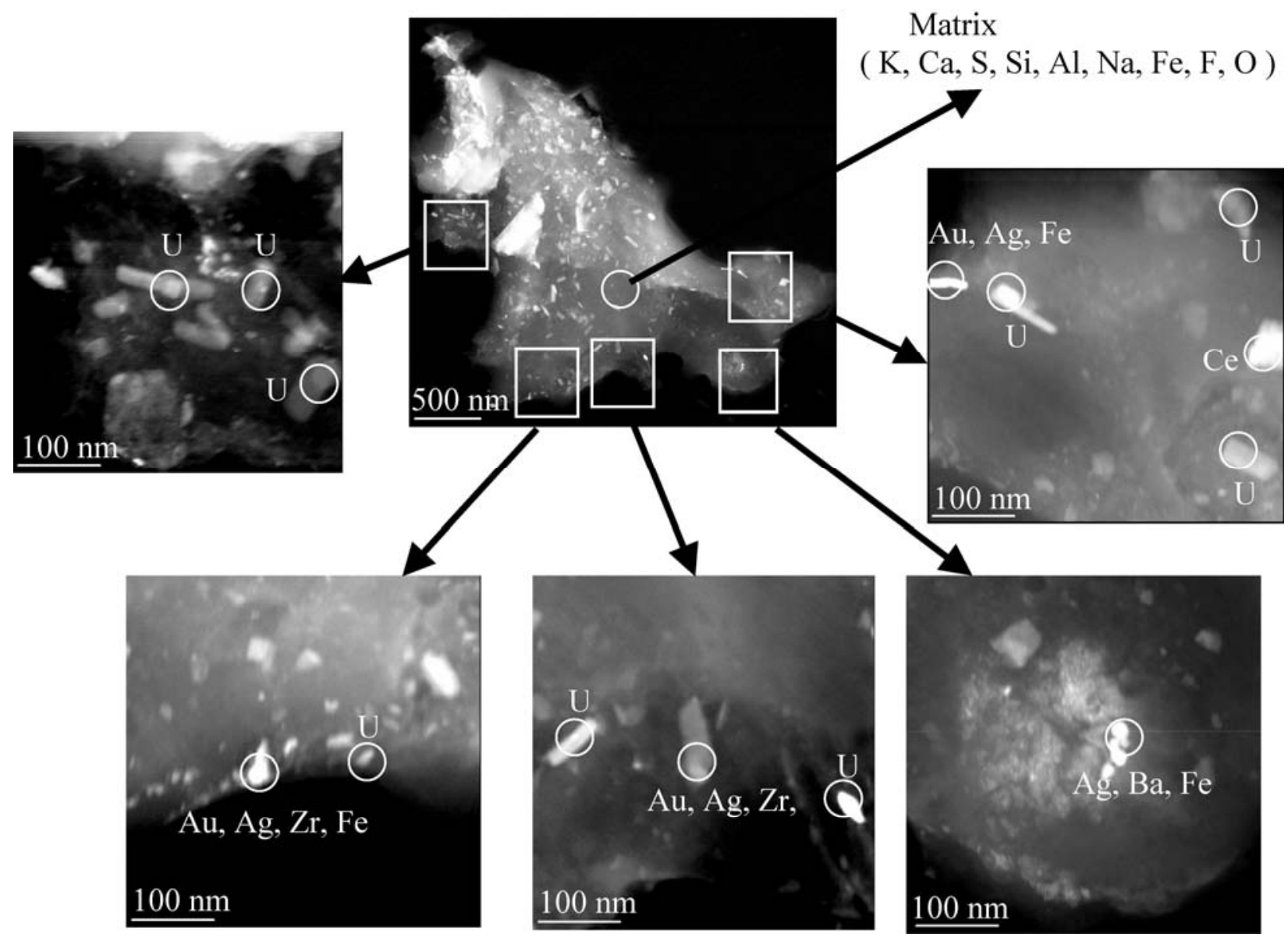

Figure 2. HAADF STEM image showing the distribution of $\mathrm{U}, \mathrm{Au}, \mathrm{Ag}, \mathrm{Zr}, \mathrm{Ba}, \mathrm{Ce}$, Fe containing colloids filtered from ground water samples at the Nevada Test Sites. 


\title{
Chapter 5
}

\section{Stable Isotope Investigation of Precipitation and Recharge Processes in Central Nevada}

\author{
Timothy Rose
}

\section{Introduction}

This report summarizes work conducted by Lawrence Livermore National Laboratory (LLNL) during FY 2003 in support of a continuing investigation of precipitation and recharge processes in central Nevada. The study is funded by the Hydrologic Resources Management Program (HRMP), National Nuclear Security Administration, Nevada Site Office, and includes two separate but interrelated activities:

(1) Precipitation, spring water, and shallow infiltration samples are collected at four locations in central Nevada on a biannual basis at sites maintained by LLNL. Stable isotope analyses of these samples are used to determine the relative contribution of cool and warm season precipitation to the recharge budget, and to evaluate the timing and extent of evaporation during recharge. This part of the project was initiated in FY 1999, and is fully described in the FY2001-2002 HRMP-UGTA progress report (Rose et al., 2003).

(2) Precipitation samples are collected on a biannual basis at High Altitude Precipitation (HAP) stations that the U.S. Geological Survey (USGS) maintains throughout east-central and southern Nevada. LLNL runs stable isotope analyses on these samples. The HAP sites are situated at a range of elevations (7,760 to $10,745 \mathrm{ft}$ ), all of which are higher in altitude than the four sites that LLNL currently maintains in central Nevada $(7,000$ to $7,490 \mathrm{ft})$. Hence, the HAP sites can provide insight into variations in isotopic composition as a function of altitude. Moreover, because the HAP sites are distributed over a wide geographic area, regional variations in the isotopic composition of precipitation can be evaluated. This portion of the study was initiated in FY 2003.

\section{FY 2003 Results}

\section{LLNL Monitoring Sites}

Samples were collected at the LLNL monitoring sites in October 2002 and May 2003. Precipitation, spring water, and lysimeter (shallow infiltration) data are compiled in Tables 1, 3 and 4, respectively (all tables are at the end of this report). Data from previous years are included for comparison. Table 2 summarizes the mean precipitation amounts and isotopic values for each site. The precipitation samples collected in October 2002 reflect rainfall events that occurred during the summer of 2002. The "summer" samples from Pinto, Little Antelope, and Currant Summits are isotopically depleted $(\delta$ - 
values are more negative) compared to the average warm season precipitation at these sites. This suggests a cool weather pattern during the summer of 2002, or a significant rainfall contribution from at least one cold storm system. The winter precipitation collected in May 2003 tends to be slightly enriched in heavy isotopes relative to the cool season weighted mean $\delta \mathrm{D}$ and $\delta^{18} \mathrm{O}$ values (compare Table 1 and 2), although variations from the mean values are small. Snowfall amounts during the winter of 2002-03 exceeded the winter averages at all four sites.

The weighted mean isotopic values of precipitation (Table 2) did not change significantly from values reported in Rose et al. (2003) with the exception of the warm season averages, which decreased by 1.5 and 0.9 permil in $\delta^{18} \mathrm{O}$ at Little Antelope and Currant Summits, respectively. This suggests that existing data record has not yet "converged" on a representative mean isotopic composition for all of the monitoring sites. On average, between 18.3 and $22.5 \%$ of the total precipitation fell during the warm season, compared with 77.5 to $81.7 \%$ during the cool season.

Springs located near each of the precipitation gauges are nearly constant in isotopic composition over time (Table 3). Austin Spring showed a major shift in composition in May 2002, but returned to "normal" by October 2002, and was completely dry in May 2003. (In October 2003, Austin Spring was once again flowing at $0.1 \mathrm{~L} / \mathrm{min}$; these observations may suggest that recharge from the previous winter takes a number of months to reach this spring).

In October 2002, we deployed two lysimeters at each monitoring site in order to compare infiltration volumes and isotopic compositions. In previous years only one lysimeter was installed at each site. The lysimeters were located 1 to 3 meters apart, and were buried with the top of the collection funnel at $10 \mathrm{~cm}$ depth. Although we attempted to create identical sampling conditions for each collector, the volume of water that accumulated and its isotopic composition varied at each site (see Table 4). Several factors likely contributed to the observed differences, including variations in soil compaction, depth of the snow pack above each collector, and the local snowmelt infiltration rate. As in prior years, the collectors that received smaller volumes of infiltration tended to exhibit more evaporated isotopic signatures. Samples that have undergone significant evaporation plot below the global meteoric water line (GMWL; see Figure 1). Evaporation effects tend to be most pronounced in samples where the infiltration amount is $<1 \mathrm{~cm}$. As additional lysimeter data are acquired, we hypothesize that the weighted mean isotopic value of the infiltration will lie between the mean precipitation value and that of the local spring. This will tend to verify that the evaporation signature observed at the springs is due to water vapor loss in the shallow soil layer.

\section{$\underline{\text { USGS HAP Sites }}$}

Since the mid 1980s, the USGS has maintained a high-elevation precipitation monitoring network at sites in eastern and southeastern Nevada. In January 2002, LLNL began discussions with Jon Wilson (USGS, Las Vegas) regarding the possibility of running $\delta \mathrm{D}$ and $\delta^{18} \mathrm{O}$ measurements on precipitation samples from these sites. 


\section{Lysimeter Data}

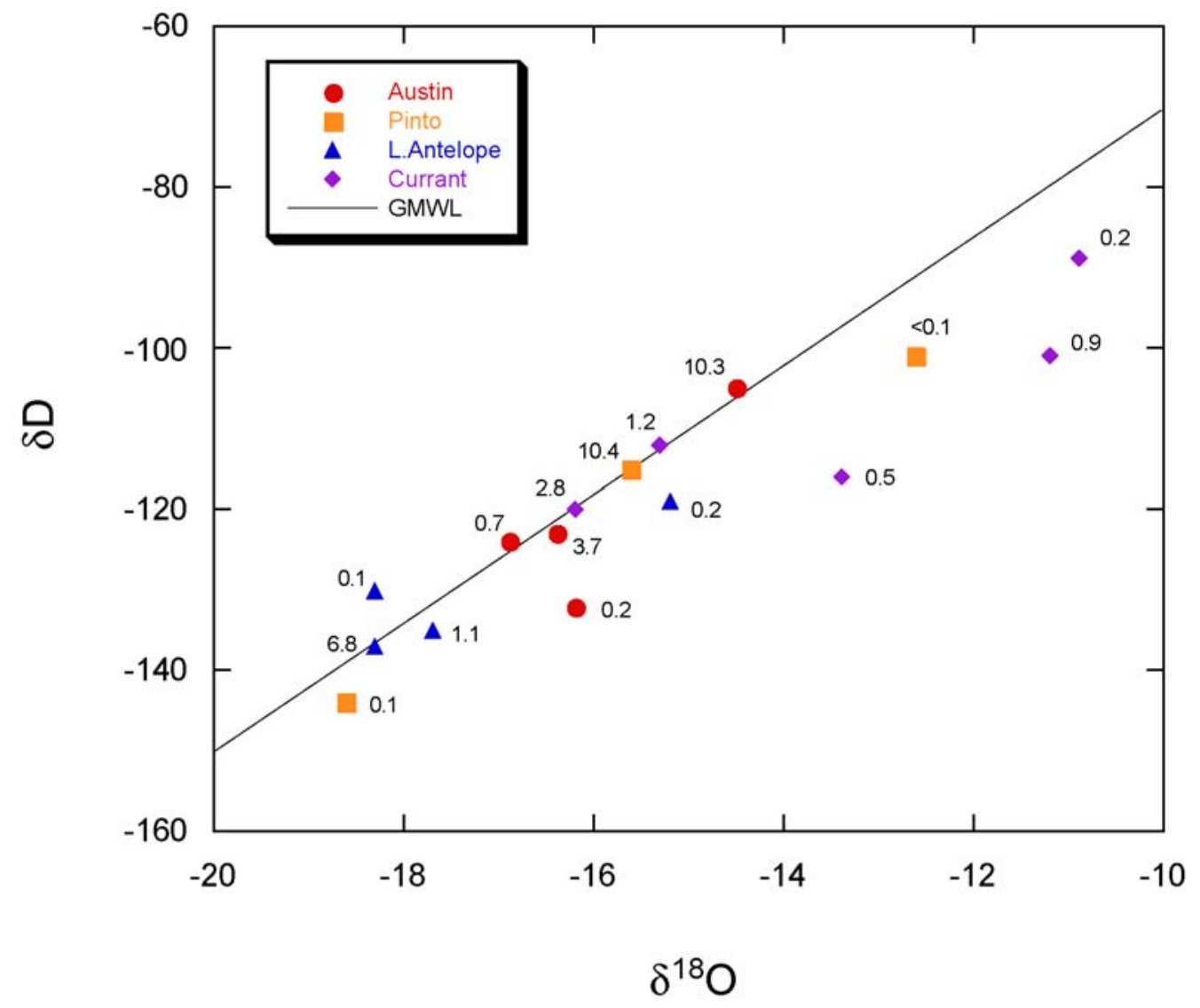

Figure 1. Plot of $\delta \mathrm{D}$ vs. $\delta^{18} \mathrm{O}$ values of shallow infiltration samples from lysimeters in central Nevada (2000-2003). The values next to each data point are the infiltration amount (in $\mathrm{cm}$ of rainfall equivalent).

At the time, anti-freeze was being used in the gauges, which precluded the possibility of stable isotope analyses. Following these discussions, it was agreed that we would attempt replacing the antifreeze with a known volume distilled water + mineral oil (the latter to prevent evaporation). Due to the design of the gauges, some water needs to be left in the gauge to facilitate water level determinations. The amount of precipitation that accumulates in the gauge between visits is determined from the change in water level.

The USGS visited the high altitude precipitation (HAP) sites in June 2002 at which time they cleaned out the gauges and added distilled water and mineral oil. A small aliquot of the distilled water from each gauge was sent to LLNL for isotopic analysis. The first set of precipitation samples were subsequently collected in late October and early November 2002, and samples were again returned to LLNL for analysis. The data are summarized in Table 5. 
The first row of data in Table 5 shows the initial fill volume for each gauge (June 2002) and the measured $\delta \mathrm{D}$ and $\delta^{18} \mathrm{O}$ values of the distilled water. The second row of data gives the measured precipitation amount (in inches), the total volume of water in each gauge, and the precipitation volume. The latter two quantities were calculated using the equation for the volume of a right circular cylinder, $V=\pi r^{2} h$, where $r$ is the radius of the gauge ( $6 \mathrm{in}$.) and $\mathrm{h}$ is the measured height of the water column. The third row of data includes the measured $\delta \mathrm{D}$ and $\delta^{18} \mathrm{O}$ values of samples collected in October / November 2002 , the precipitation volume fraction $\left(\mathrm{V}_{\text {precip }}\right.$ divided by $\left.\mathrm{V}_{\text {total }}\right)$, and the calculated $\delta \mathrm{D}$ and $\delta^{18} \mathrm{O}$ values of the precipitation. The isotopic composition of the precipitation was estimated using a two component mixing equation:

$$
\delta_{\mathrm{m}}=\left(\delta_{\mathrm{i}}\right)\left(X_{\mathrm{i}}\right)+\left(\delta_{\mathrm{p}}\right)\left(X_{\mathrm{p}}\right)
$$

where $\delta_{\mathrm{m}}$ is the measured isotopic value $\left(\delta \mathrm{D}\right.$ or $\left.\delta^{18} \mathrm{O}\right)$ of the mixed sample (distilled water + precipitation), $\delta_{\mathrm{i}}$ is the measured isotopic value of the initial distilled water, $\delta_{\mathrm{p}}$ is the calculated isotopic value of the precipitation, and $X_{\mathrm{i}}$ and $X_{\mathrm{p}}$ are the volume fractions of the distilled water and precipitation, respectively (where $X_{\mathrm{i}}+X_{\mathrm{p}}=1$ ). This method yields reasonably accurate results if the relative volumes are well constrained. Given that the calculated volume fractions depend on accurate water column observations, differences in atmospheric pressure during different visits to a site are a potential source of error in the calculation.

A more serious issue in the case of the HAP samples collected in October / November 2002 is that a number of the samples were partially evaporated. Figure 2 shows a $\delta \mathrm{D}$ vs. $\delta^{18} \mathrm{O}$ plot of the calculated precipitation values for the HAP sites. Many of the samples plot below the global meteoric water line (GMWL), indicating losses due to evaporation. In some cases, the evaporation produced exceptional heavy isotope enrichments (e.g. samples from the S. Delamar and Sheep Peak sites). Although each gauge contained two liters of mineral oil, this was apparently insufficient to prevent evaporation from occurring - possibly due to solar heating of the metal gauges. The fact that evaporation has never been an issue at the precipitation monitoring sites maintained by LLNL may be related to the fact that the PVC pipe used in the those gauges has different thermal properties. Only four of the HAP samples have calculated $\delta \mathrm{D}-\delta^{18} \mathrm{O}$ pairs that appear to be non-evaporated (Highland Peak, Lee Canyon, Kyle Canyon, and Cave Mtn). The results for these samples may be reasonably close to the actual composition of precipitation that fell at the sites. However, two of the samples plot slightly above the GMWL, likely reflecting cumulative errors in the calculated values due to uncertainties in the isotopic measurements and the water column readings.

The marginal results of this initial exercise suggested a different approach was needed. The two biggest issues were related to evaporation and the need for mass balance calculations. To circumvent these problems, the USGS designed and built smaller collectors that are independent of the existing precipitation gauges. The new gauges will still employ mineral oil to prevent evaporation, but they are made of plastic instead of metal and should therefore not retain as much heat as the HAP gauges. Moreover, there is no need to put distilled water in the gauge at the time of deployment, thereby 


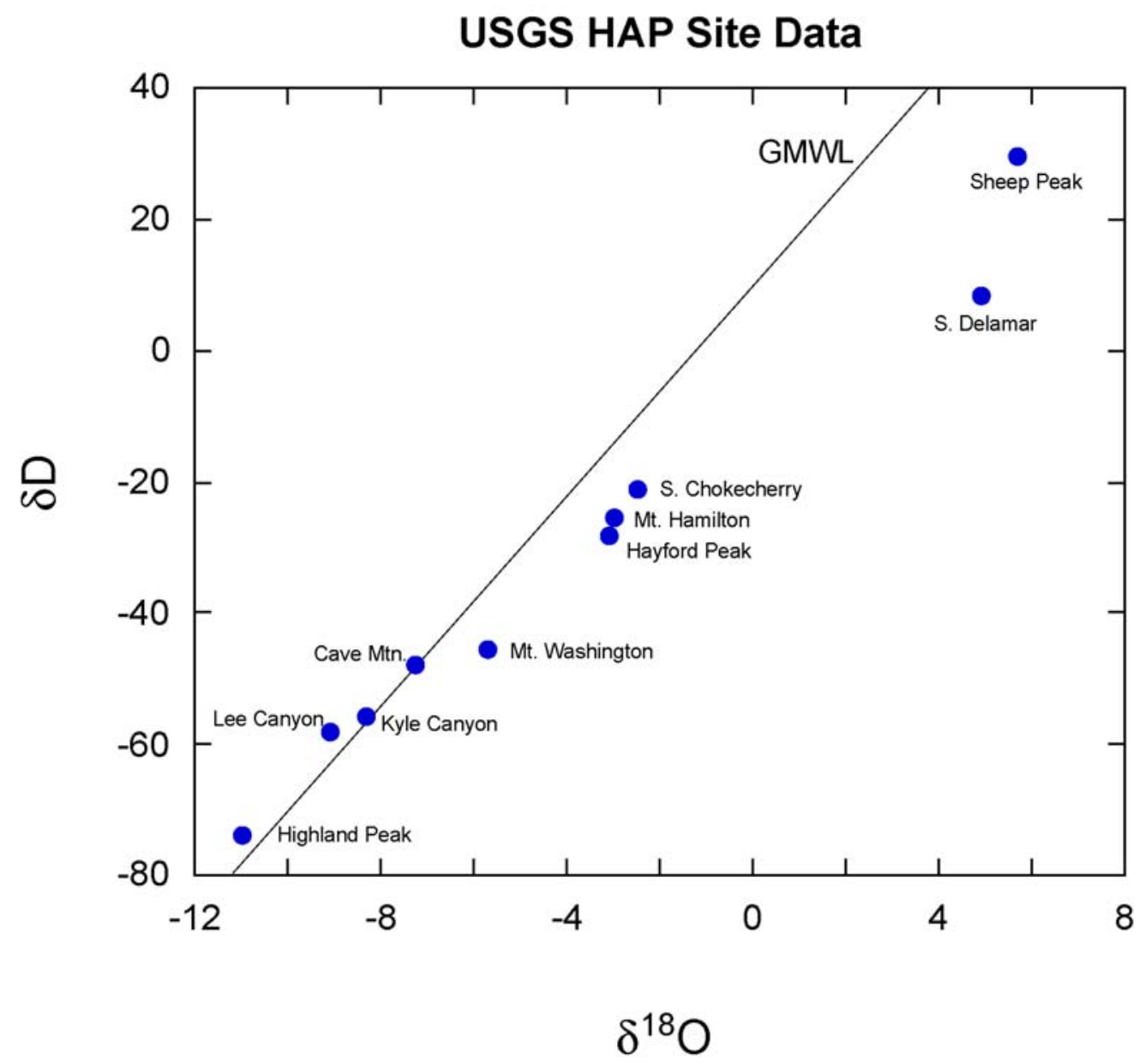

Figure 2. Plot of $\delta \mathrm{D}$ vs. $\delta^{18} \mathrm{O}$ values of precipitation samples from the USGS High Altitude Precipitation (HAP) monitoring network in eastern and southeastern Nevada.

eliminating the mass balance calculation. The new gauges were deployed along side the HAP gauges at five sites in June 2003, and the first set of samples will be retrieved in October 2003. If this approach is successful, we will expand the number of gauging sites in the future.

\section{Discussion and Recommendations for Future Work}

Very few long-term records exist for the stable isotope composition of precipitation, groundwater infiltration, and natural spring sites. These data are of considerable value to the development of conceptual models for hydrologic processes, for validating numerical groundwater flow models, and for developing climate models. The continuation of the projects described in this report will help build a database of lasting value to future hydrologic investigations in Nevada. 
The data record at the LLNL monitoring sites is approaching the point where it may be useful in modeling the recharge water balance. In particular, it is of interest to develop quantitative constraints on how much of the precipitation is lost to net evaporation during infiltration. The variation in the lysimeter data suggests that infiltration is a strongly heterogeneous process. During the next year, we plan to design a different type of lysimeter that will capture infiltration over a larger area, so that localized "fast paths" are averaged out. It is also of interest to better understand how soil properties are influencing infiltration rates. We have observed that the amount of infiltration collected in the lysimeters tends to be much lower at certain sites (e.g. Pinto Summit). Running some simple permeameter experiments on soil samples would yield insight into how much water the soil can hold, and will provide an estimate of the hydraulic conductivity of the soil (cf. Freeze and Cherry, 1979).

Once we have developed a reliable sampling routine for the HAP sites, the resulting data will provide important insight into regional variations in the isotopic composition of precipitation in Nevada. Assuming the five newly designed collectors are successful, the USGS will expand their sampling efforts to include more of the HAP sites in the coming

year. In addition, two new HAP sites are presently being established, which will increase our geographic coverage of the region.

\section{References}

Freeze, R.A. and Cherry, J.A. (1979) Groundwater. Prentice-Hall, Englewood Cliffs, N.J., 604 p.

Rose, T.P., Eaton, G.F., and Kersting, A.B., eds. (2003) Hydrologic Resources Management Program and Underground Test Area Project FY2001-2002 Progress Report. Lawrence Livermore National Laboratory Report Internal Report. UCRL-ID-154357, 134 p. 
Table 1. Precipitation data.

\begin{tabular}{|c|c|c|c|c|}
\hline $\begin{array}{c}\text { Location I } \\
\text { Sample Date }\end{array}$ & $\begin{array}{l}\text { Time } \\
\text { Period }\end{array}$ & $\begin{array}{l}\text { Precipitation } \\
\text { Amount }(\mathrm{cm})\end{array}$ & $\begin{array}{l}\delta^{18} \mathrm{O} \\
(\%)\end{array}$ & $\begin{array}{l}\delta \mathrm{D} \\
(\%)\end{array}$ \\
\hline $\begin{array}{l}\text { Austin Summit } \\
16-J u l-99 \\
1-\text { Nov-99 } \\
15-\text { May-00 } \\
\text { 16-Oct-00 } \\
\text { 14-May-01 } \\
24-O c t-01 \\
22-\text { May-02 } \\
\text { 9-Oct-02 } \\
\text { 23-May-03 }\end{array}$ & $\begin{array}{l}01 / 99-07 / 99 \\
07 / 99-10 / 99 \\
11 / 99-05 / 00 \\
05 / 00-10 / 00 \\
10 / 00-05 / 01 \\
05 / 01-10 / 01 \\
10 / 01-05 / 02 \\
05 / 02-10 / 02 \\
10 / 02-05 / 03\end{array}$ & $\begin{array}{c}13.7 \\
0.7 \\
11.0 \\
7.1 \\
12.1 \\
2.1 \\
17.3 \\
3.2 \\
18.1\end{array}$ & $\begin{array}{c}-14.7 \\
-5.9 \\
-17.1 \\
-12.0 \\
-15.8 \\
-6.2 \\
-14.6 \\
-8.9 \\
-15.1\end{array}$ & $\begin{array}{l}-107 \\
-41 \\
-131 \\
-92 \\
-116 \\
-39 \\
-105 \\
-61 \\
-110\end{array}$ \\
\hline $\begin{array}{l}\text { Pinto Summit } \\
\text { 16-Jul-99 } \\
2 \text {-Nov-99 } \\
\text { 15-May-00 } \\
\text { 16-Oct-00 } \\
\text { 14-May-01 } \\
24-O c t-01 \\
23-M a y-02 \\
\text { 9-Oct-02 } \\
\text { 23-May-03 }\end{array}$ & $\begin{array}{l}01 / 99-07 / 99 \\
07 / 99-10 / 99 \\
11 / 99-05 / 00 \\
05 / 00-10 / 00 \\
10 / 00-05 / 01 \\
05 / 01-10 / 01 \\
10 / 01-05 / 02 \\
05 / 02-10 / 02 \\
10 / 02-05 / 03\end{array}$ & $\begin{array}{c}20.7 \\
2.6 \\
19.5 \\
12.6 \\
25.9 \\
3.9 \\
23.4 \\
6.4 \\
27.8\end{array}$ & $\begin{array}{c}-15.9 \\
-8.3 \\
-16.1 \\
-12.3 \\
-16.7 \\
-6.6 \\
-15.2 \\
-11.0 \\
-16.0\end{array}$ & $\begin{array}{l}-119 \\
-50 \\
-117 \\
-89 \\
-121 \\
-43 \\
-111 \\
-79 \\
-118\end{array}$ \\
\hline $\begin{array}{l}\text { Little Antelope } \\
\text { 16-Jul-99 } \\
2 \text {-Nov-99 } \\
16-M a y-00 \\
16-O c t-00 \\
\text { 14-May-01 } \\
24-O c t-01 \\
23-M a y-02 \\
9-O c t-02 \\
\text { 23-May-03 }\end{array}$ & $\begin{array}{l}\text { nmit } \\
01 / 99-07 / 99 \\
07 / 99-10 / 99 \\
11 / 99-05 / 00 \\
05 / 00-10 / 00 \\
10 / 00-05 / 01 \\
05 / 01-10 / 01 \\
10 / 01-05 / 02 \\
05 / 02-10 / 02 \\
10 / 02-05 / 03\end{array}$ & $\begin{array}{c}21.4 \\
6.1 \\
17.2 \\
9.0 \\
23.4 \\
5.1 \\
23.6 \\
5.5 \\
24.4\end{array}$ & $\begin{array}{c}-15.7 \\
-6.7 \\
-17.4 \\
-10.6 \\
-17.6 \\
-5.6 \\
-15.2 \\
-15.1 \\
-15.7\end{array}$ & $\begin{array}{l}-116 \\
-37 \\
-128 \\
-75 \\
-131 \\
-35 \\
-111 \\
-113 \\
-116\end{array}$ \\
\hline $\begin{array}{l}\text { Currant Summit } \\
\text { 17-Jul-99 } \\
\text { 3-Nov-99 } \\
16-\text { May-00 } \\
17-O c t-00 \\
15-M a y-01 \\
24-O c t-01 \\
23-M a y-02 \\
\text { 10-Oct-02 } \\
\text { 22-May-03 }\end{array}$ & $\begin{array}{l}01 / 99-07 / 99 \\
07 / 99-10 / 99 \\
11 / 99-05 / 00 \\
05 / 00-10 / 00 \\
10 / 00-05 / 01 \\
05 / 01-10 / 01 \\
10 / 01-05 / 02 \\
05 / 02-10 / 02 \\
10 / 02-05 / 03\end{array}$ & $\begin{array}{c}--- \\
3.1 \\
16.7 \\
7.2 \\
21.4 \\
5.5 \\
12.7 \\
4.1 \\
17.6\end{array}$ & $\begin{array}{c}--- \\
-6.6 \\
-16.1 \\
-9.4 \\
-16.6 \\
-5.8 \\
-16.5 \\
-11.9 \\
-15.6\end{array}$ & $\begin{array}{c}--- \\
-41 \\
-118 \\
-66 \\
-120 \\
-36 \\
-121 \\
-86 \\
-115\end{array}$ \\
\hline
\end{tabular}


Table 2. Mean precipitation amounts and isotopic values.

\begin{tabular}{|c|c|c|c|c|c|c|c|c|}
\hline & Aust & n Summit & \multicolumn{2}{|c|}{ Pinto Summit } & \multicolumn{2}{|c|}{$\begin{array}{l}\text { Little Antelope } \\
\text { Summit }\end{array}$} & \multicolumn{2}{|c|}{ Currant Summit } \\
\hline & \multicolumn{8}{|c|}{ Mean Precipitation Amounts (past 4 years) } \\
\hline & \multicolumn{2}{|r|}{$(\mathrm{cm})$} & \multicolumn{2}{|c|}{$(\mathrm{cm})$} & \multicolumn{2}{|c|}{$(\mathrm{cm})$} & \multicolumn{2}{|c|}{$(\mathrm{cm})$} \\
\hline \multirow{5}{*}{$\begin{array}{l}\text { Annual } \\
\text { Warm Season } \\
\text { Cool Season }\end{array}$} & & 17.9 & \multicolumn{2}{|c|}{30.5} & \multicolumn{2}{|c|}{28.6} & \multicolumn{2}{|c|}{22.1} \\
\hline & & 3.3 & \multicolumn{2}{|c|}{6.4} & \multicolumn{2}{|c|}{6.4} & \multicolumn{2}{|c|}{5.0} \\
\hline & & 14.6 & \multicolumn{2}{|c|}{24.1} & \multicolumn{2}{|c|}{22.2} & \multicolumn{2}{|c|}{17.1} \\
\hline & \multicolumn{8}{|c|}{ Weighted Mean Isotopic Values } \\
\hline & $\begin{array}{l}\delta^{18} \mathrm{O} \\
(\% \circ)\end{array}$ & $\begin{array}{l}\delta D \\
(\%)\end{array}$ & $\begin{array}{l}\delta^{18} \mathrm{O} \\
(\%)\end{array}$ & $\begin{array}{l}\delta \mathrm{D} \\
(\% \circ)\end{array}$ & $\begin{array}{l}\delta^{18} \mathrm{O} \\
(\%)\end{array}$ & $\begin{array}{c}\delta \mathrm{D} \\
(\% \circ)\end{array}$ & $\begin{array}{l}\delta^{18} \mathrm{O} \\
(\%)\end{array}$ & $\begin{array}{c}\delta \mathrm{D} \\
(\% 0)\end{array}$ \\
\hline Full Record & -14.5 & -106 & -15.0 & -110 & -15.0 & -110 & -14.5 & -105 \\
\hline Past 4 Years & -14.5 & -106 & -14.9 & -108 & -14.9 & -109 & -14.5 & -105 \\
\hline Warm Season (4 yrs) & -10.0 & -73 & -10.7 & -75 & -9.7 & -66 & -8.5 & -58 \\
\hline Warm Season (4 yrs) & -15.5 & -114 & -16.0 & -117 & -16.4 & -121 & -16.2 & -118 \\
\hline
\end{tabular}


Table 3. Spring water data.

\begin{tabular}{|c|c|c|c|c|c|c|c|}
\hline $\begin{array}{l}\text { Location I } \\
\text { Sample Date }\end{array}$ & $\begin{array}{c}\text { Est. Flow } \\
\text { Rate (L/min) }\end{array}$ & $\begin{array}{l}\text { Temp. } \\
\left({ }^{\circ} \mathrm{C}\right)\end{array}$ & $\mathrm{pH}$ & $\begin{array}{l}\text { Cond. } \\
\text { (mS/cm) }\end{array}$ & $\begin{array}{c}\text { Alkalinity } \\
\text { (mg/L) }\end{array}$ & $\begin{array}{l}\delta^{18} \mathrm{O} \\
(\%)\end{array}$ & $\begin{array}{c}\delta \mathrm{D} \\
(\%)\end{array}$ \\
\hline \multicolumn{8}{|c|}{ Austin Summit Spring } \\
\hline 1-Nov-99 & 1.0 & 9 & 7.83 & 239 & 125 & -16.0 & -118 \\
\hline 15-May-00 & 0.2 & 13 & 7.05 & 275 & 115 & -16.1 & -117 \\
\hline $16-$ Oct-00 & 0.1 & 6 & 7.20 & 315 & n.d. & -15.9 & -116 \\
\hline 14-Мау-01 & $<0.1$ & 18 & 7.05 & 277 & 140 & -15.9 & -118 \\
\hline 24-Oct-01 & $<0.1$ & 7 & 7.80 & 377 & 150 & -15.9 & -120 \\
\hline 22-May-02 & 0.3 & 7 & 7.15 & 311 & 130 & -14.6 & -107 \\
\hline 9-Oct-02 & 1.5 & 10 & 7.35 & 333 & n.d. & -15.9 & -122 \\
\hline 23-Мау-03 & dry & n.d. & n.d. & n.d. & n.d. & n.d. & n.d. \\
\hline
\end{tabular}

\section{Pinto Summit Spring}

\begin{tabular}{lccccccc} 
2-Nov-99 & 5.0 & 4 & 8.10 & 299 & 175 & -15.2 & -120 \\
15-May-00 & 15.0 & 7 & 7.50 & 395 & 150 & -15.7 & -120 \\
16-Oct-00 & 2.0 & 5 & 7.69 & 372 & n.d. & -15.4 & -122 \\
14-May-01 & 3.0 & 12 & 8.02 & 373 & 185 & -15.4 & -121 \\
24-Oct-01 & 3.0 & 5 & 8.02 & 418 & 180 & -15.2 & -119 \\
23-May-02 & 6.0 & 15 & 7.50 & 460 & 175 & -15.1 & -121 \\
9-Oct-02 & 7.5 & 12 & 7.82 & 400 & n.d. & -15.5 & -121 \\
23-May-03 & 10.0 & 18 & 8.36 & 368 & 200 & -15.7 & -122 \\
\hline
\end{tabular}

\section{Little Antelope Spring}

\begin{tabular}{|c|c|c|c|c|c|c|c|}
\hline 2-Nov-99 & 1.0 & 9 & 7.08 & 1421 & 350 & -15.5 & -122 \\
\hline 16-May-00 & 1.0 & 8 & 6.98 & 1661 & 400 & -15.7 & -122 \\
\hline 16-Oct-00 & 1.0 & 9 & 6.76 & 1665 & n.d. & -15.6 & -124 \\
\hline 14-May-01 & 0.9 & 8 & 6.95 & 1684 & 350 & -15.6 & -125 \\
\hline 24-Oct-01 & 1.0 & 9 & 7.05 & 1520 & 400 & -15.6 & -126 \\
\hline 23-May-02 & 0.8 & 8 & 7.05 & 1521 & 400 & -15.6 & -125 \\
\hline 9-Oct-02 & 0.8 & 9 & 6.79 & 1601 & n.d. & -15.6 & -125 \\
\hline 23-May-03 & 0.75 & 9 & 7.10 & 1630 & 350 & -15.6 & -123 \\
\hline \multicolumn{8}{|c|}{ Currant Summit Spring } \\
\hline 3-Nov-99 & 0.5 & 12 & 7.51 & 381 & 170 & -13.9 & -108 \\
\hline 16-May-00 & 0.1 & 2 & 7.20 & 477 & 160 & -13.9 & -110 \\
\hline 17-Oct-00 & 0.3 & 8 & 7.21 & 446 & n.d. & -14.0 & -112 \\
\hline 15-Мау-01 & 1.2 & 13 & 7.72 & 456 & 160 & -14.0 & -112 \\
\hline 24-Oct-01 & 0.3 & 8 & 7.51 & 402 & 175 & -13.9 & -111 \\
\hline 23-May-02 & 0.1 & 7 & 7.52 & 388 & 175 & -13.9 & -109 \\
\hline 10-Oct-02 & 0.2 & 14 & 7.10 & 524 & n.d. & -13.9 & -110 \\
\hline 22-May-03 & 0.03 & 25 & 8.41 & 513 & 175 & -13.8 & -109 \\
\hline
\end{tabular}

n.d. = not determined 
Table 4. Lysimeter data.

\begin{tabular}{|c|c|c|c|c|c|}
\hline $\begin{array}{l}\text { Location I } \\
\text { Sample Date }\end{array}$ & $\begin{array}{l}\text { Time } \\
\text { Period }\end{array}$ & $\begin{array}{l}\text { Infiltration } \\
\text { Amount } \\
\text { (cm) }\end{array}$ & $\begin{array}{l}\text { Infiltration I } \\
\text { Precipitation } \\
\text { (ratio) }\end{array}$ & $\begin{array}{l}\delta^{18} \mathrm{O} \\
(\% \circ)\end{array}$ & $\begin{array}{l}\delta D \\
(\% \circ)\end{array}$ \\
\hline \multicolumn{6}{|l|}{ Austin Summit } \\
\hline 15-May-00 & $11 / 99-05 / 00$ & 0.2 & 0.02 & -16.2 & -132 \\
\hline 14-May-01 & $10 / 00-05 / 01$ & 0.7 & 0.06 & -16.9 & -124 \\
\hline 22-May-02 & 10/01 - 05/02 & 10.3 & 0.59 & -14.5 & -105 \\
\hline $\begin{array}{l}\text { 23-May-03 (\#1) } \\
\text { 23-May-03 (\#2) }\end{array}$ & $\begin{array}{l}10 / 02-05 / 03 \\
10 / 02-05 / 03\end{array}$ & $\begin{array}{c}\text { sample lost } \\
3.7\end{array}$ & 0.20 & ---- & --- \\
\hline \multicolumn{6}{|l|}{ Pinto Summit } \\
\hline 15-May-00 & $11 / 99-05 / 00$ & $<0.1$ & $<0.01$ & -12.6 & -101 \\
\hline 14-May-01 & $10 / 00-05 / 01$ & 10.4 & 0.40 & -15.6 & -115 \\
\hline 23-May-02 & $10 / 01-05 / 02$ & $<0.1$ & $<0.01$ & --- & --- \\
\hline $\begin{array}{l}\text { 23-May-03 (\#1) } \\
\text { 23-May-03 (\#2) }\end{array}$ & $\begin{array}{l}10 / 02-05 / 03 \\
10 / 02-05 / 03\end{array}$ & $\begin{array}{l}<0.1 \\
0.1\end{array}$ & $\begin{array}{l}<0.01 \\
<0.01\end{array}$ & $---\overline{-}$ & $\begin{array}{l}-119 \\
-144\end{array}$ \\
\hline \multicolumn{6}{|c|}{ Little Antelope Summit } \\
\hline 16-May-00 & $11 / 99-05 / 00$ & $<0.1$ & $<0.01$ & --- & --- \\
\hline 14-May-01 & $10 / 00-05 / 01$ & 0.1 & $<0.01$ & -18.3 & -130 \\
\hline 23-May-02 & $10 / 01-05 / 02$ & 0.2 & 0.01 & -15.2 & -119 \\
\hline $\begin{array}{l}\text { 23-May-03 (\#1) } \\
\text { 23-May-03 (\#2) }\end{array}$ & $\begin{array}{l}10 / 02-05 / 03 \\
10 / 02-05 / 03\end{array}$ & $\begin{array}{l}6.8 \\
1.1\end{array}$ & $\begin{array}{l}0.37 \\
0.04\end{array}$ & $\begin{array}{l}-18.3 \\
-17.7\end{array}$ & $\begin{array}{l}-137 \\
-134\end{array}$ \\
\hline \multicolumn{6}{|l|}{ Currant Summit } \\
\hline 16-May-00 & $11 / 99-05 / 00$ & 2.8 & 0.17 & -16.2 & -120 \\
\hline 15-May-01 & $10 / 00-05 / 01$ & 1.2 & 0.06 & -15.3 & -112 \\
\hline 23-May-02 & $10 / 01-05 / 02$ & 0.5 & 0.04 & -13.4 & -116 \\
\hline $\begin{array}{l}\text { 22-May-03 (\#1) } \\
\text { 22-May-03 (\#2) }\end{array}$ & $\begin{array}{l}10 / 02-05 / 03 \\
10 / 02-05 / 03\end{array}$ & $\begin{array}{l}0.9 \\
0.2\end{array}$ & $\begin{array}{l}0.07 \\
0.01\end{array}$ & $\begin{array}{l}-11.2 \\
-10.9\end{array}$ & $\begin{array}{c}-101 \\
-89\end{array}$ \\
\hline
\end{tabular}


Table 5. USGS HAP Site Data.

\begin{tabular}{|c|c|c|c|c|}
\hline Site Name & $\begin{array}{l}\text { Initial Fill } \\
\text { Date }\end{array}$ & $\begin{array}{c}\text { Initial Fill } \\
\text { Volume } \\
\text { (June 02) } \\
\text { (L) }\end{array}$ & $\begin{array}{c}\text { Initial Fill } \\
\delta^{18} \mathrm{O} \\
(\%)\end{array}$ & $\begin{array}{c}\text { Initial Fill } \\
\delta \mathrm{D} \\
(\%)\end{array}$ \\
\hline Cherry Creek & 10-Jun-02 & 8.80 & -8.06 & -63.5 \\
\hline Cave Mtn & 11-Jun-02 & 5.56 & -7.44 & -54.8 \\
\hline Mt Washington & 12-Jun-02 & 10.19 & -7.44 & -55.1 \\
\hline Highland Peak & 13-Jun-02 & 11.11 & -7.44 & -52.7 \\
\hline S. Chokecherry & 13-Jun-02 & 12.50 & -7.51 & -56.2 \\
\hline Lee Canyon & 17-Jun-02 & 8.80 & -7.48 & -54.8 \\
\hline Kyle Canyon & 17-Jun-02 & 12.04 & -7.62 & -54.9 \\
\hline Mt. Hamilton & 18-Jun-02 & 6.48 & -0.16 & -7.2 \\
\hline Mt. Irish & 18-Jun-02 & 13.43 & -0.54 & -6.1 \\
\hline S. Delamar & 18-Jun-02 & 9.26 & -0.27 & -6.7 \\
\hline Hayford Peak & 19-Jun-02 & 12.04 & -0.67 & -5.7 \\
\hline Sheep Peak & 19-Jun-02 & 12.50 & -1.25 & -10.4 \\
\hline Mt. Wilson & 26-Jun-02 & 5.56 & -0.47 & -3.8 \\
\hline Site Name & $\begin{array}{c}\text { Sample } \\
\text { Date }\end{array}$ & $\begin{array}{l}\text { Precipitation } \\
\text { Amount } \\
\text { (Oct/Nov 02) } \\
\text { (inches) }\end{array}$ & $\begin{array}{c}\text { Total Gauge } \\
\text { Volume } \\
\text { (Oct/Nov 02) } \\
\text { (L) }\end{array}$ & $\begin{array}{c}\text { Precipitation } \\
\text { Volume } \\
\text { (Oct/Nov 02) } \\
\text { (L) }\end{array}$ \\
\hline Cherry Creek & no sample* & 3.75 & 15.75 & 6.95 \\
\hline Cave Mtn & 31-Oct-02 & 7.50 & 19.46 & 13.90 \\
\hline Mt Washington & 4-Nov-02 & 5.00 & 19.46 & 9.27 \\
\hline Highland Peak & 5-Nov-02 & 1.50 & 13.89 & 2.78 \\
\hline S. Chokecherry & 5-Nov-02 & 1.50 & 15.28 & 2.78 \\
\hline Lee Canyon & 14-Nov-02 & 4.75 & 17.60 & 8.80 \\
\hline Kyle Canyon & 14-Nov-02 & 6.50 & 24.09 & 12.05 \\
\hline Mt. Hamilton & 31-Oct-02 & 8.00 & 21.31 & 14.83 \\
\hline Mt. Irish & 30-Oct-02 & 0.00 & 13.43 & 0.00 \\
\hline S. Delamar & 30-Oct-02 & 8.00 & 24.09 & 14.83 \\
\hline Hayford Peak & 30-Oct-02 & 5.50 & 22.23 & 10.19 \\
\hline Sheep Peak & 30-Oct-02 & 1.25 & 14.82 & 2.32 \\
\hline Mt. Wilson & no sample* & 5.00 & 14.83 & 9.27 \\
\hline
\end{tabular}


Table 5. Continued

\begin{tabular}{|c|c|c|c|c|c|c|}
\hline Site Name & $\begin{array}{c}\text { Sample } \\
\text { Date }\end{array}$ & $\begin{array}{c}\text { Total Volume } \\
\delta^{18} \mathrm{O} \\
\text { (Oct/Nov 02) }\end{array}$ & $\begin{array}{c}\text { Total Volume } \\
\text { \&D } \\
\text { (Oct/Nov 02) }\end{array}$ & $\begin{array}{l}\text { Precip. } \\
\text { Volume } \\
\text { Fraction }\end{array}$ & $\begin{array}{c}\text { Precipitation } \\
\delta^{18} O \\
\text { (calculated) }\end{array}$ & $\begin{array}{c}\text { Precipitation } \\
\delta \mathrm{D} \\
\text { (calculated) }\end{array}$ \\
\hline Cherry Creek & no sample* & --- & --- & 0.441 & --- & --- \\
\hline Cave Mtn & 31-Oct-02 & -7.31 & -49.7 & 0.714 & -7.26 & -47.7 \\
\hline Mt Washington & 4-Nov-02 & -6.63 & -50.5 & 0.476 & -5.74 & -45.4 \\
\hline Highland Peak & 5-Nov-02 & -8.15 & -56.9 & 0.200 & -10.99 & -73.7 \\
\hline S. Chokecherry & 5-Nov-02 & -6.60 & -49.8 & 0.182 & -2.51 & -21.0 \\
\hline Lee Canyon & 14-Nov-02 & -8.30 & -56.4 & 0.500 & -9.12 & -58.0 \\
\hline Kyle Canyon & 14-Nov-02 & -7.97 & -55.2 & 0.500 & -8.32 & -55.5 \\
\hline Mt. Hamilton & 31-Oct-02 & -2.12 & -19.7 & 0.696 & -2.98 & -25.2 \\
\hline Mt. Irish & 30-Oct-02 & +0.63 & +0.4 & 0.000 & --- & --- \\
\hline S. Delamar & 30-Oct-02 & +2.90 & +2.7 & 0.616 & +4.88 & +8.6 \\
\hline Hayford Peak & 30-Oct-02 & -1.78 & -15.9 & 0.458 & -3.09 & -28.0 \\
\hline Sheep Peak & 30-Oct-02 & -0.16 & -4.1 & 0.157 & +5.69 & +29.7 \\
\hline Mt. Wilson & no sample* & --- & --- & 0.625 & --- & --- \\
\hline
\end{tabular}

* Precipitation samples were not collected at the Cherry Creek and Mt. Wilson sites in Oct / Nov 2002 because the water in the gauges was frozen. 